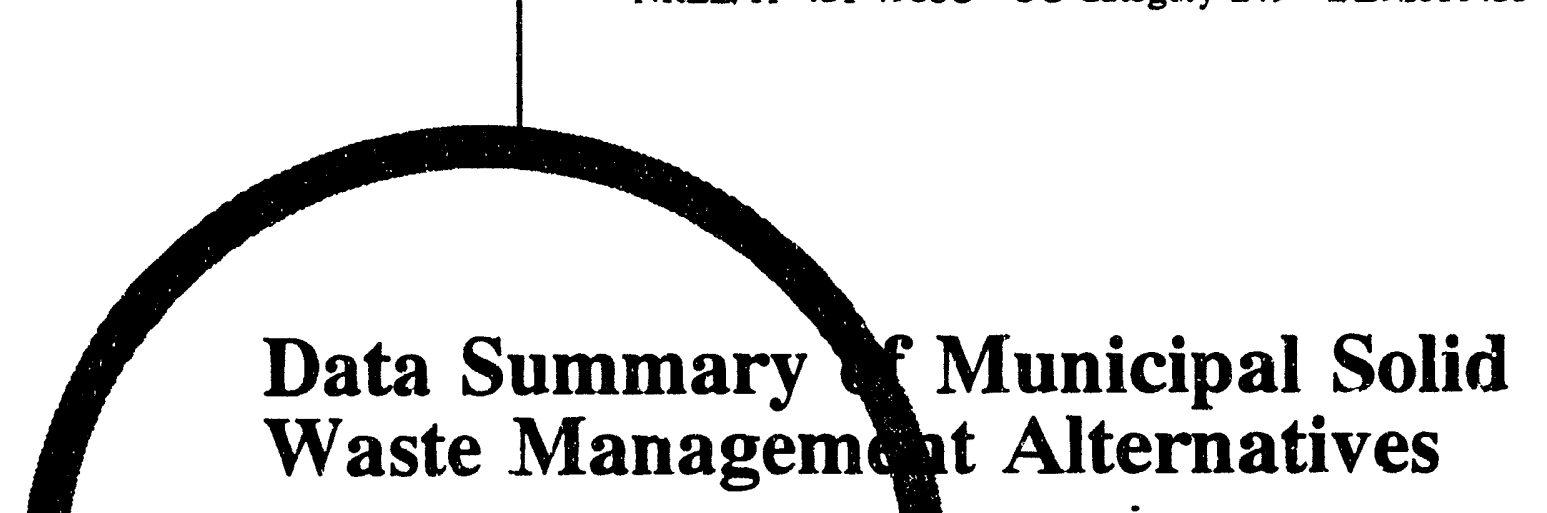

Volume III: Appen x A-Mass Burn Technologies

SRI International

Menlo Park, California

NREL Technical Monitors: Bimleshwar Gupta Philip Shepherd

National Renewable Energy Laboratory

(formerly the Solar Energy Research Institute)

1617 Cole Boulevard

Golden, Colorado 80401-3393

A Division of Midwest Research Institute Operated for the U.S. Department of Energy under Contract No. DE-AC02-83CH10093

Prepared under subcontract no: RF-1-1103

October 1992 


\section{Report Organization}

This report. Data Summary of Municipal Solid Waste Management Alternatives, comprises 12 separately bounci volumes. Volume I contains the report text. Volume II contains supporting exhibits. Volumes III through X are appendices, each addressing a specific MSW management technology. Volumes XI and XII contain project bibliographies. The document control page at the back of this volume contains contacts for obtaining copies of the other volumes.

\begin{tabular}{|c|c|c|}
\hline Volume & Contents & Document Number \\
\hline I & Report Text & TP-431-4988A \\
\hline II & Exhibits & TP-431-4988B \\
\hline III & $\begin{array}{l}\text { Appendix A } \\
\text { Mass Bum Technologies }\end{array}$ & TP-431-4988C \\
\hline IV & $\begin{array}{l}\text { Appendix B } \\
\text { RDF Technologies }\end{array}$ & TP-431-4988D \\
\hline V & $\begin{array}{l}\text { Appendix C } \\
\text { Fluidized-Bed Combustion }\end{array}$ & TP-431-4988E \\
\hline V! & $\begin{array}{l}\text { Appendix D } \\
\text { Pyrolysis and Gasification } \\
\text { of MSW }\end{array}$ & TP-431-4988F \\
\hline VII & $\begin{array}{l}\text { Appendix E } \\
\text { Material Recovery/Material } \\
\text { Recycling Technologies }\end{array}$ & TP-431-4988G \\
\hline VIII & $\begin{array}{l}\text { Appendix F } \\
\text { Landfills }\end{array}$ & TP-431-4988H \\
\hline IX & $\begin{array}{l}\text { Appendix G } \\
\text { Composting }\end{array}$ & TP-431-4988I \\
\hline $\mathbf{X}$ & $\begin{array}{l}\text { Appendix } \mathrm{H} \\
\text { Anaerobic Digestion of MSW }\end{array}$ & TP-431-4988J \\
\hline XI & $\begin{array}{l}\text { Alphabetically Indexed } \\
\text { Bibliography }\end{array}$ & TP-431-4988K \\
\hline XII & $\begin{array}{l}\text { Numerically Indexed } \\
\text { Bibliography }\end{array}$ & TP-431-4988L \\
\hline
\end{tabular}


A.1 INTRODUCTIONOVERVIEW A-1

A.1.1 Types of Mass Bum Systems A-2

A.1.1.1 Fiold-Erected Facilitios A-3

A.1.1.2 Moctular Factulios A-4

A.1.2 Status . A-4

A.2 TECHNOLOGY DESCRIPTION A-10

A.2.1 Field-Erectod Systems $\quad$ A-10

A.2.1.1 Refractory Systems $\quad$ A-16

A.2.1.2 Watenwall Systems

A.2.2 Mocular Systems $\quad$ A-18

A.2.3 Energy Recovery and Power Generation A-22

A.2.4 Residue Handing A-24

A.2.5 Air Pollution Control Systems $\quad$ A-25

A.2.5.1 Good Combustion Practice A-29

A.2.5.2 APC Equipment A-31

A.2.6 System Vendors A-35

A.2.6.1 Fiold Erected Systems $\quad$ A-35

$\begin{array}{lll}\text { A.2.6.2 Modular Systems } & \text { A-42 }\end{array}$

A.3 ECONOMIC DATA A-47

A.3.1 Field Erected Units $\quad$ A-49

A.3.1.1 Capital Losts A-49

A.3.1.2 Operation and Maintenance Costs A-52

A.3.2 Modular Systems A.54

A.3.2.1 Capital Costs A-54

A.3.2.2 Operation and Maintenance Costs A-55

A.3.3 Air Pollution Control Equipment Costs A-55

A.4 MASS AND ENERGY BALANCE A-62

A.5 ENVIRONMENTAL RELEASESIMPACTS A-67

$\begin{array}{lll}\text { A.5.1 Air Emissions } & \text { A-67 }\end{array}$

A.5.2 Wastewater Discharge A-72

A.5.3 Ash Residue A-73

A.5.3.1 Landfill Disposal $\quad$ A.76

A.5.3.2 Treatment A-76

$\begin{array}{lll}\text { A.5.3.3 Uses of Ash } & \text { A-81 }\end{array}$

$\begin{array}{ll}\text { REFERENCES } & \text { A-83 }\end{array}$ 


\section{TABLE OF CONTENTS (CONA)}

\section{Altechment}

Page

1

2

3

4

5

6

7

8

9

10

11

Grate Manufecturers - Mass Bum Facillies

$1-1$

Boller Manufacturers - Mass Bum Fecillies

2-1

Capital Costs - Flold-Erected Mass Bum Facllties Grouped by APC Method

3-1

Capital Costs - Flold-Erected Mass Bum Facillies Grouped by

Type of Energy Production

$4-1$

OsM Costs - Field-Erected Mass Bum Facillies

$5-1$

Stafting Lovets - Field-Erected Mass Bum Facillies

6-1

Capital Costs - Moctular Mass Bum Facillties Grouped by APC Method

$7-1$

Copltal Costs - Modular Mass Bum Fecillies Grouped by Type of

Energy Production

$8-1$

OsM Costs - Mocular Mass Bum Facillies

9-1

Statting Levels - Modular Mass Bum Facilities

10-1

Power Production - Mass Bum Facillities

$11-1$ 


\section{UST OF TABLES}

1991 Performance Standands and Emission Guidelines for Now and Existing MWC Facillies

Summary of Capltal Cost by Energy Type in 1990 STPD for Field Erected Mass Bum Facillies

Estimated Annualized Operating Costs of Emission Control Systems for Now Model MWC Facilities

Estimated Capital Costs of Emission Control Systems for

Existing Model Refractory MWC Facilities

Estimated Annualized Operating Costs of Emission Control System for

Existing Model Refractory MWC Facilities

Estimated Capital Costs of Emission Control Systems for

Existing $N$ xdel Watenwall MWC Facilities

Estimates, Annualized Operating Costs of Emission Control Systems for Existing Model Waterwall MWC Facilities

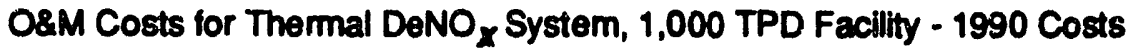




\section{UST OF TABLES (CONA)}

Iable

A-20 APC Capture Efficiencies

\section{LST OF ILUSTRATIONS}

A-1 Mass Bum Facilly - Generic Flow Diagram A-11

A-2 Detroit Stoker Reciprocating Grate Stoker A-14

A-3 Deutsche-Babcock Dusseldort Roller Grate A-14

A-4 Waterwall Rotary Combustor A-15

A-5 Typical Refrectory Lined Boller System - Vound A-17

A-6 Typical Watenwall Boiler System - Martin A-19

A-7 Modular Mass Bum System - Consumat A-21

A-8 Moctular Mass Bum System - Basic Enwironmental Engineering A-21

A-9 Basic Components of a Wasto-to-Energy System with a Condensing Turbine A-23

A-10 Components of Typical Dry Scrubber/Fabric Filter Spray Dryer System A-29

A-11 Mass and Energy Balance - 500 TPD Mass Bum Facilly A-63

A-12 Mass and Energy Balance - 2,000 TPD Mass Bum Facilty. A-65 


\section{APPENDIX A.}

\section{MASS BURN TECHNOLOGIES}

This appendix on Mass Bum Technoboies is the first in a series designed to identify, describe and assess the sulkabilty of several currently or potentially avallable generic technologies for the management of municipal solid waste (MSW). These appendices, which cover eight core thermoconversion, bioconversion and recycling technologies, refiect public domain information gathered from many sources. Representative sources inchude: professional joumal articles, conference proceedings, selected municipality solid waste management plans and subscription technology data bases. The information presented is intended to serve as background information that will faciltate the preparation of the technoeconomic and me cycle mass, energy and environmental analyses that are being developed for each of the technologies.

\section{A.1 INTRODUCTIONOVERVIEW}

Mass bum has been and continues to be the predominant technology in Europe for the management of MSW. In the United States, the majority of the existing waste-to-energy projects utilize this technology and nearly 90 percent of all currently planned facilities have selected mass bum systems (387).

Mass buming generally refers to the direct feeding and combustion of municipal solid waste in a fumace without any significant waste preprocessing. The only materials typically removed from the waste stream prior to combustion are large bulky objects and potentially hazardous or undesirable wastes. The technology has evolved over the last 100 or 80 years from simple incineration to the most highly developed and commercially proven process available for both rectucing the volume of MSW and for recovering energy in the forms of steam and electricity. In general, mass bum plants are considered to operate reliably with high availability (025).

Several system design, operations, and performance evaluation projects have been undertaken to characterize the economics, energy, and environmental aspects of MSW mass buming technology (e.9., 354, 402, 471, 472, 799). A number of studies have also been conducted to address health risk concerns, and include comparisons with the other MSW management approaches such as landfills (e.g., $298,373,439,537)$. Improvements in mass bum technology continue to be made in such areas as combustor design, ash residue handling, pollution control eojipment, and continuous emissions monitoring systems (402). 
Recently planned faciltites such as those in Monmouth County, Now Jersey and Gaston County, North Carolina plan to incorporate frontend processing systems that are expected to significantly improve facilly operabilty as well as enable the recovery of recyclables from MSW. Whith this integrated approach, materials that could adver. soly affect combustion (aluminum and glass) or cause potentially serious emissions problems (household batteries) when burned, are removed from the MSW prior to combustion.

The types of mass bum systems are defined below followed by the current status of facilities employing this technology. Section A-2 presents tectinology descriptions, followed by economic data (capltal and OsM cost data) in Section A-3, energy production and usage information in Section A-4, and a summary of environmental releases and impacts data in Section A-5. It should be noted that much of the actual data neported in the data tables were derived from the 1991 Resource Recovery Yearbook (387) and data base developed by Govermmental Advisory Associates, Inc. Solected groupings of data and analyses were developed from the overall data base specifically for this study.

\section{A.1.1 Typee of Mass Bum Syetems}

MWC facilities that utilize the mass bum technology can be classified according to the nature of construction; i.e., field erected or modular shop fabricated (472). Field-erected systems are usually modium- to large-scale (200 to 3000 TPD) watenwall or refractory-lined furnaces that combust MSW under excess air conditions while modular systems are usually small-scale (Up to 300 TPD) systems comprised of predesigned modules that are manutactured at a factory and assembled onsite. Modular systerns also feature separate primary and secondary combustion chambers and soparate heat recovery boilens (484).

The distinction between field-erected and shop-fabricated systems has become less clear in recent years as shop-fabricated installations have become larger. Many shop-fabricated systems have adopled features, such as moving grates and pit and crane systems, that were once limited to field-erected systems. In addition, lange shop-fabricated system installations may require more on-site assembly and more substantial foundations and buildings due to the large size of their component modules. At the same time, modular construction techniques are beginning to be used to reduce the costs of smaller field-ibrected systems (484). For watenwall systems, the modularization of components can recuce the a sunt of field construction and thus reduce or slow the escalation of facility costs. This would enable waterwall systems to be more cost competitive with shop-fabricated incinerator systems (574). 


\section{A.1.1.1 ElatidEnerated Fandiliten}

Mass buming of municipal solid waste has been practiced $h_{1}$ the U.S. since 1885 when an incinerator was constucted on Covernors leland, Now York (574). This facllty served only as a means of volume reduction whout any consideration given to energy recovery. The first tacility that recovered energy from the combustion of municipal solid waste began operation in 1896 in Hamburg. Germany. Two years later, the first U.S. energy recovery trom MSW facllty began operation in New York City. The abundance of inexpensive altemative fuots restricted widespread development of MSW-fired energy recovery systems in the U.S.

In the 1930s, facilties in Atlanta, Chicago, Miariu, and Louisville produced steam for space heating and industrial use. Atso, hot water heating coils were used in the secondary chambers of some refractory lined fumaces (271). Up until the earty 1940s, all U.S. mass bum incinerators were batch systems. In 1943, a continuous feed system designed by the Danish firm Volund began operations in Allanta, Georgia (574). In the mid 1950s, a breakthrough was achieved in continuous gravity feeding at the Betts Avenue incinerator plant in New York City (271). This technology breakthrough led to the development of the first waterwall continuous feed incinerator in Berne, Switzertand. European firms provided most of the subsequent technology development, due to the lack of interest in waste incineration in the U.S. in the 1960s. German and Swiss firms such as Joseph Martin Gmbh, Deutsche Babcock Anlager, and Von Roll contributed significantly to the development of continuous mass buming energy recovery systems.

The first U.S. watenwall unit was installed at the Norfok, Virginia Naval Shipyard in 1967. Designed and constructed by Foster-Wheeler, a U.S. firm, the system was procured, owned, and operated by the govemment using a relatively specialized waste stream. Thus, it was viewed as having limited relevanus in the municipal market (574).

European waterwall systems were introduced into the U.S. in 1967 when Joseph Martin Gmbh teamed with the Ovitron Corporation to bid a four unit, 1600 TPD facility in Chicago (started up in 1970). In 1969, Von Roll formed a teaming arrangement with Rust Engineering, an American firm. Other European and Japanese firms followed, establishing themselves in the L.S. market.

The enactment of the Clean Air Act of 1970 caused nearly 50 percent of the existing conventional MSW incinerators to close due to the prohibitive cost of installing the air pollution control equipment necessary for compliance. Watenwall systems presented an advantage which aided in their penetrating the market. 
Because the watertubes help cool the walls of the combustion chamber, less combustion air is required with watenwall systems than with refractory lined units. Since air pollution control equipment ske and cost are directly related to the volume of air to be treated, the recuction in combustion air was an important consideration (574). The shortage of landill space aided in spurring the development of the industry during the $1980 \mathrm{~s}$.

\section{A.1.1.2 Modvitar Fecllition}

Modular incinerators were initlally developed in the late 1950 s to address the small scale market such as apartment buildings, hospitals, a.xd commercial certers. Smoke from these types of uncontralled incinerators was a maj,sr problem and concem. Through the 1960s, modular incinerators were small batch for, refractory-lined, two chamber, contmlled air units with capacities in the range of 100 to 800 pounds per hour. More than 4,000 such systems without energy recovery were constructed in the U.S. from the late 1960s through the mid 1970 s (574).

Competition among modular system vendors led to technology advancernents with the most significant improvement being ine development of a continuous ash removal system in 1973. This improvement allowed modular facilties to operate 24 hours per day. The first modular MSW system recovering energy began operuitiogi in 1375 in Sibam Springs, Arkansas (eventually dosed and dismantled). In 1977. Consumat, the equipmert vendor, began operation of the first cortinuously operating modular MSW incinerator in North Little Flock, Arkansas. This was the first full-timi, small-scab modular system to use MSW effectively as an energy resource as well as to reduce the quanth of waste for disposal. The experience gained from this project led other communities to solicit system vendors with baith equipment supply and operations capabilities for their projects.

\section{A.1.2 Statur}

Mass bum facilities have steadily increased their share of the municipal waste combustor market. Table A-1 lists 1990 data for field-erected and modular facilities as a percentage of the total number of existing and advanced planned MWCs (387). This table clearty shows the increased interest in field-erected mass bum facilities. These facilities represent nearty double the percentage of the total number of planned MWCs compared to the total number of existing MWCs. 
TABLE A-1. MASS BURN PERCENTAGE OF TOTAL MWC MARKET(387)

\begin{tabular}{lcc} 
& Existing & Planned \\
\hline Fiold-Erected & $39 \%$ & $79 \%$ \\
Modular & $\mathbf{3 5 \%}$ & $8 \%$ \\
Tolal Mass Bum & $74 \%$ & $87 \%$ \\
& &
\end{tabular}

Table A-2 lisis the 158 existing and advanced manned U.S. mass bum facillities (387). The facillties are grouped by type as follows: refractory - 5, watenwall - 75, rotary combustor - 20, modular - 54, and sludge co-disposal - 4. As of 1990, there were 97 operational mass-bum MWCs that recovered energy in the U.S. (387), compared to approximately 503 mass-bum facilities operating worlowide (799). 


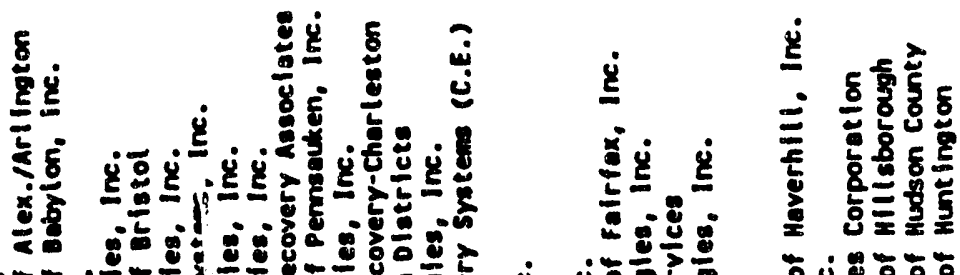

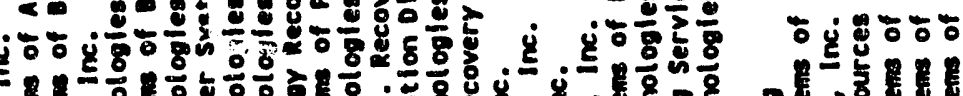

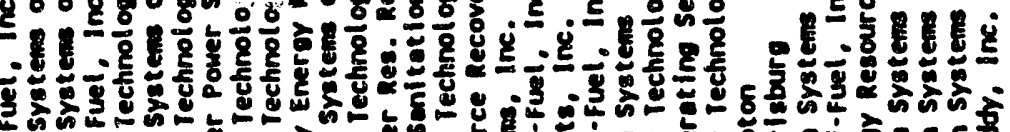

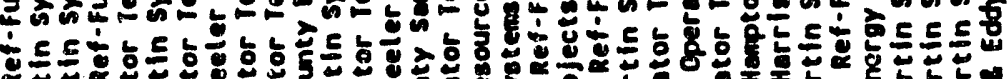
管 等

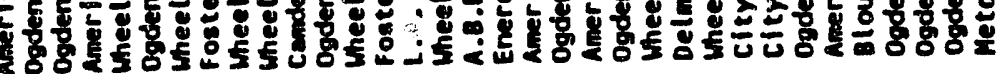

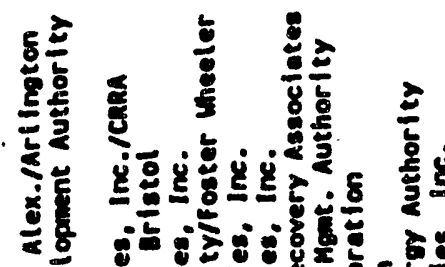

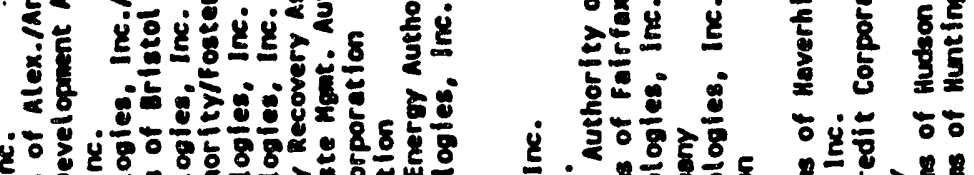

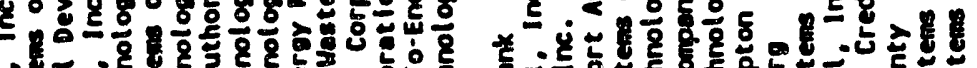

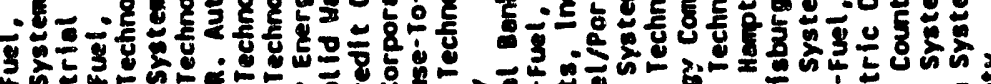

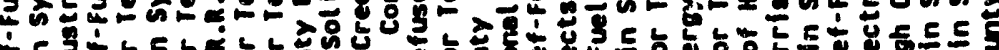
- ᄃ - 5

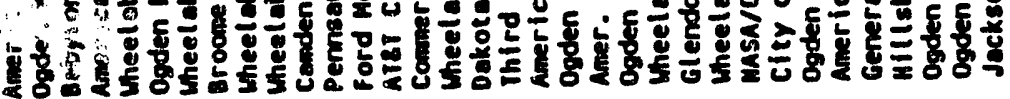

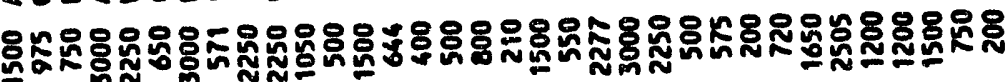

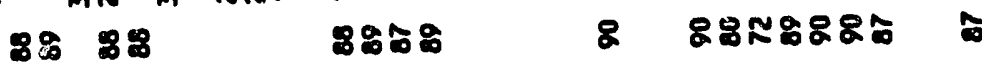

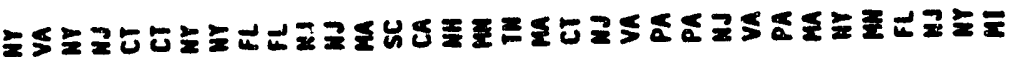
6

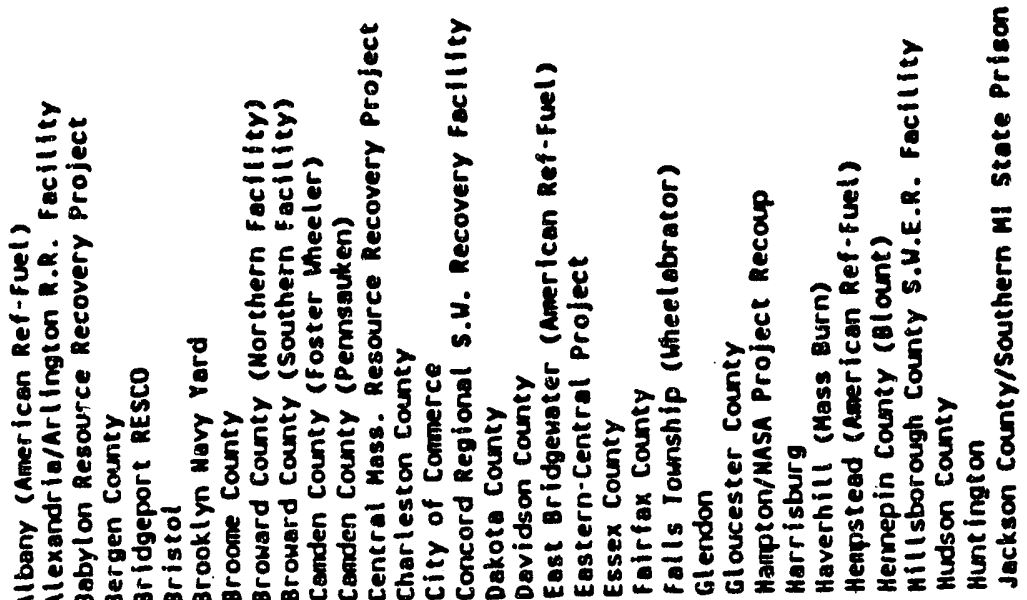




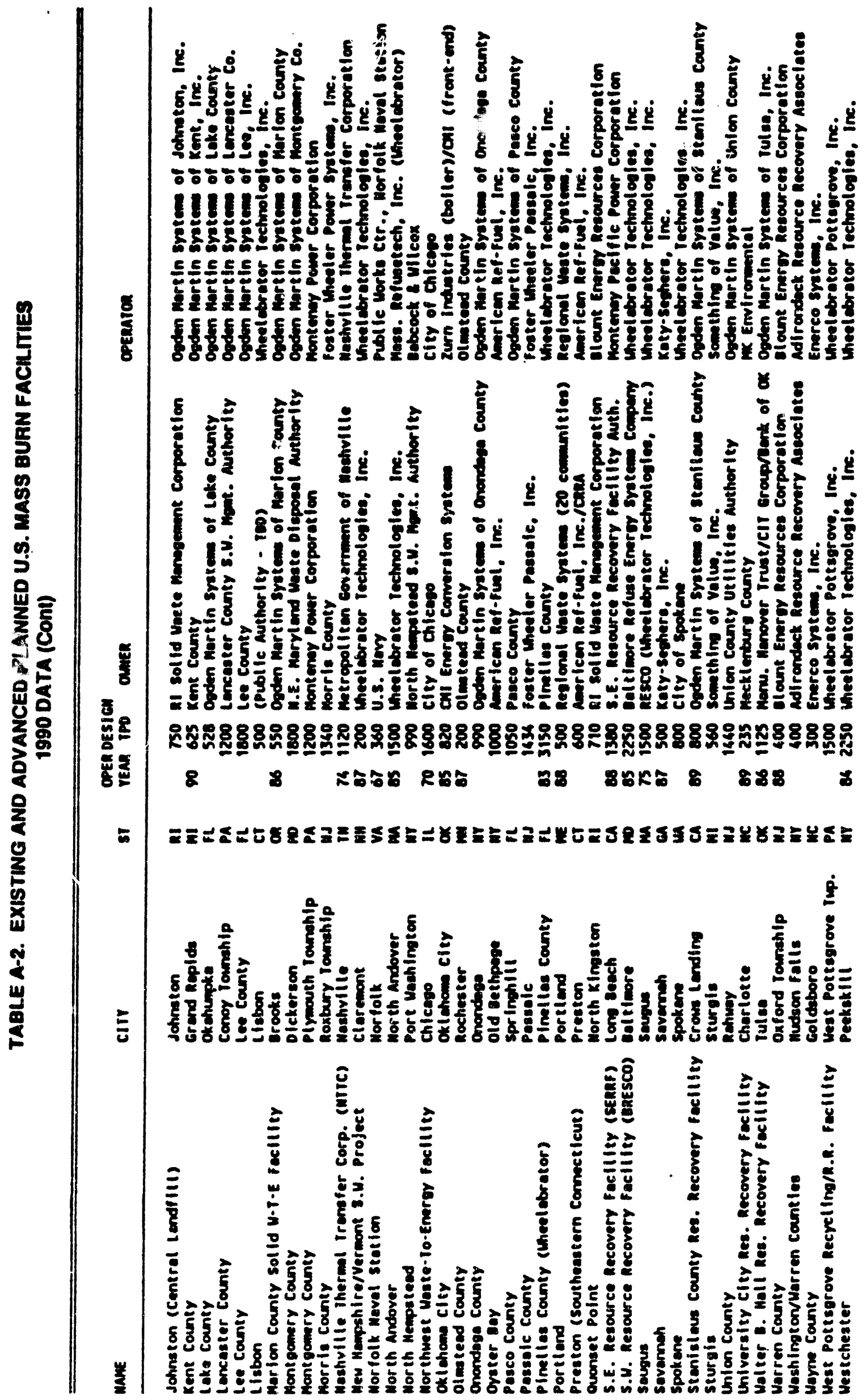


$\underline{\underline{\xi}}$

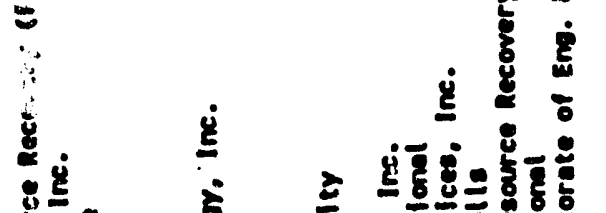

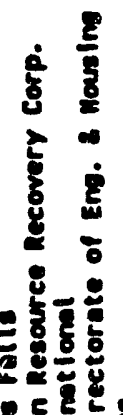

$\frac{3}{2}$

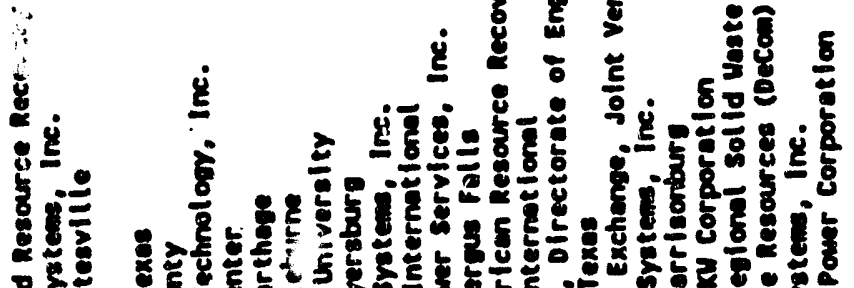

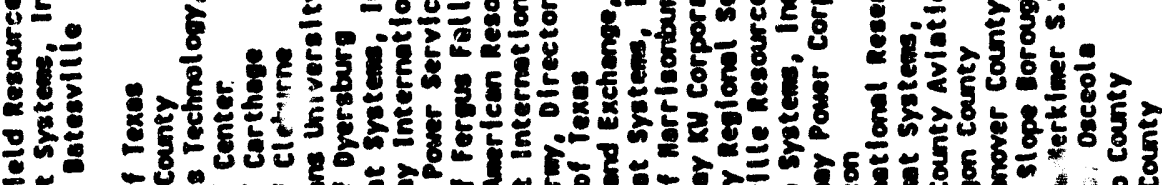

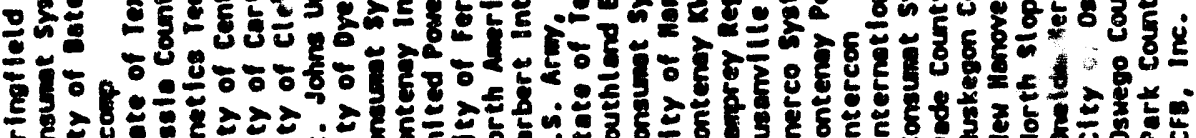

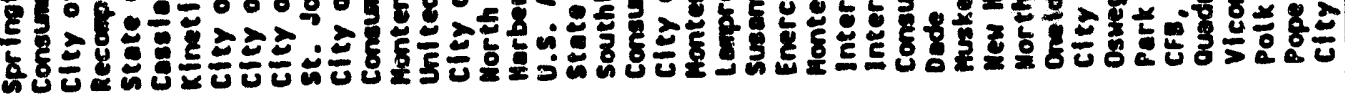

용

事

菣

8

을

ह

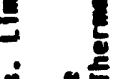

象

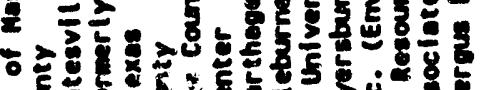

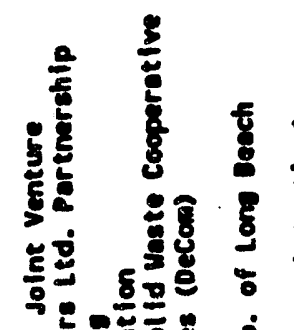

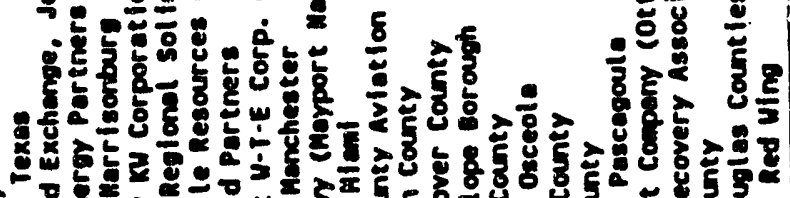

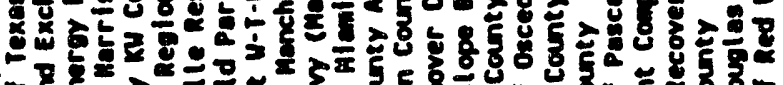

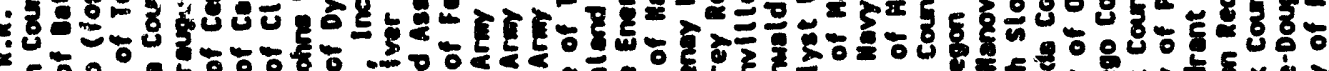

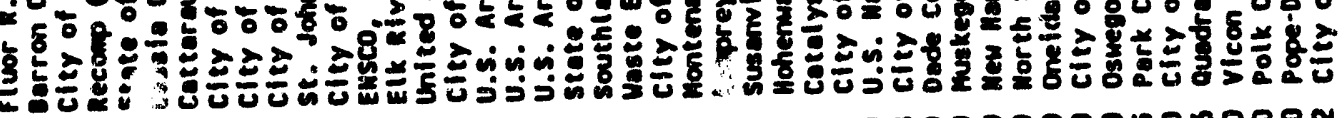

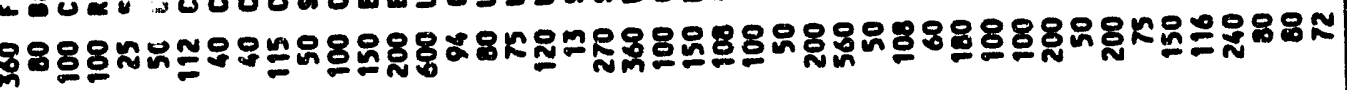

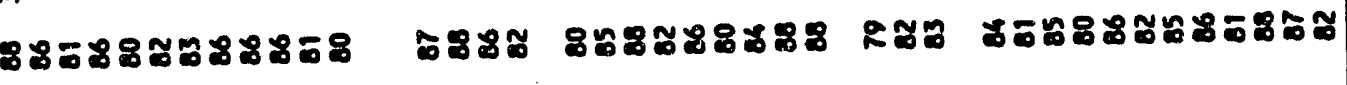

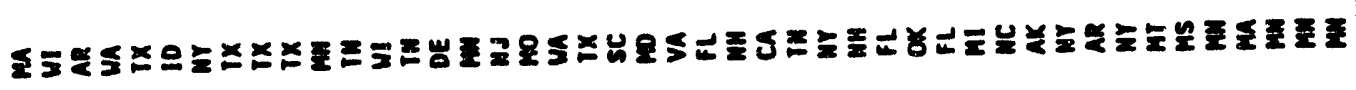
更

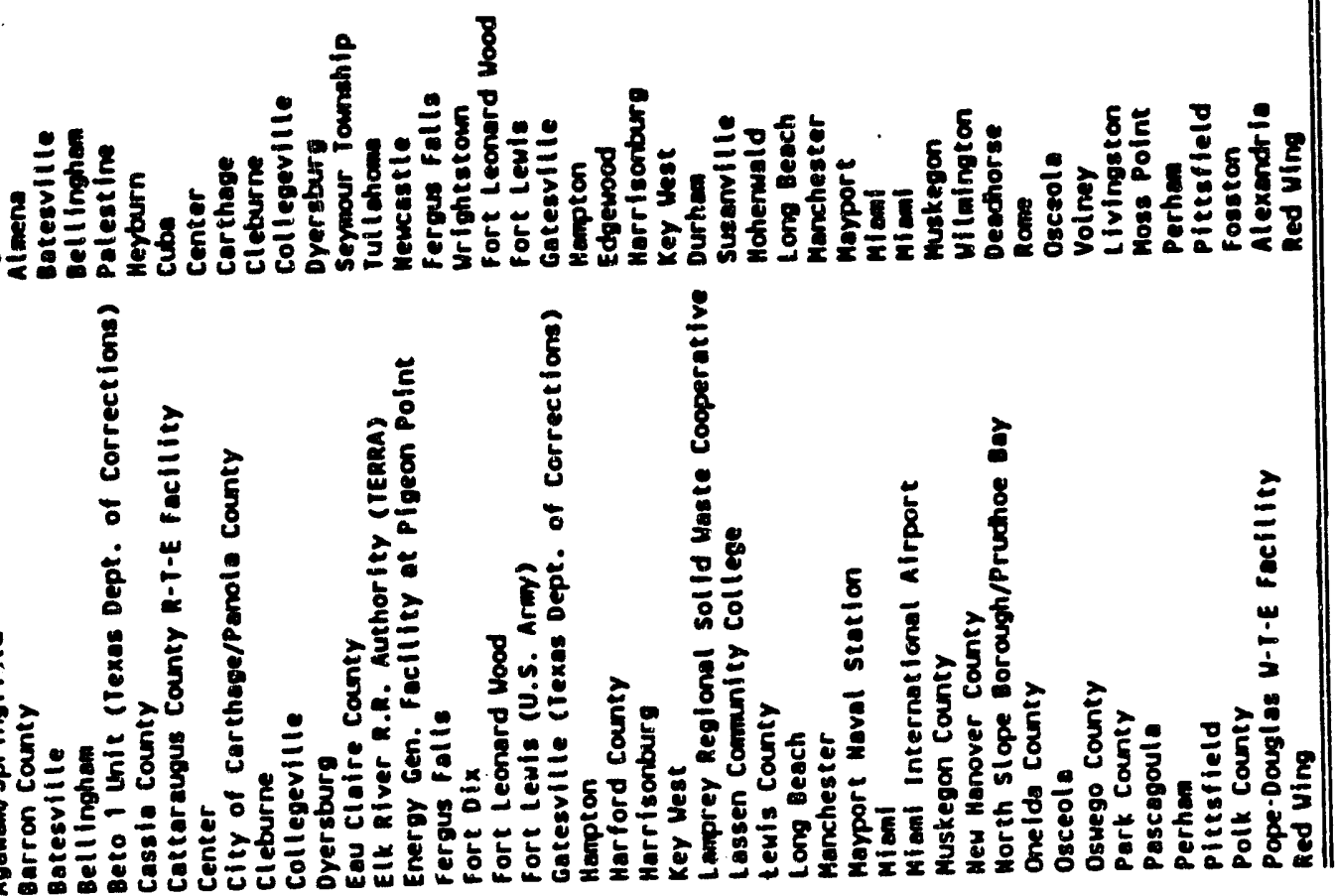




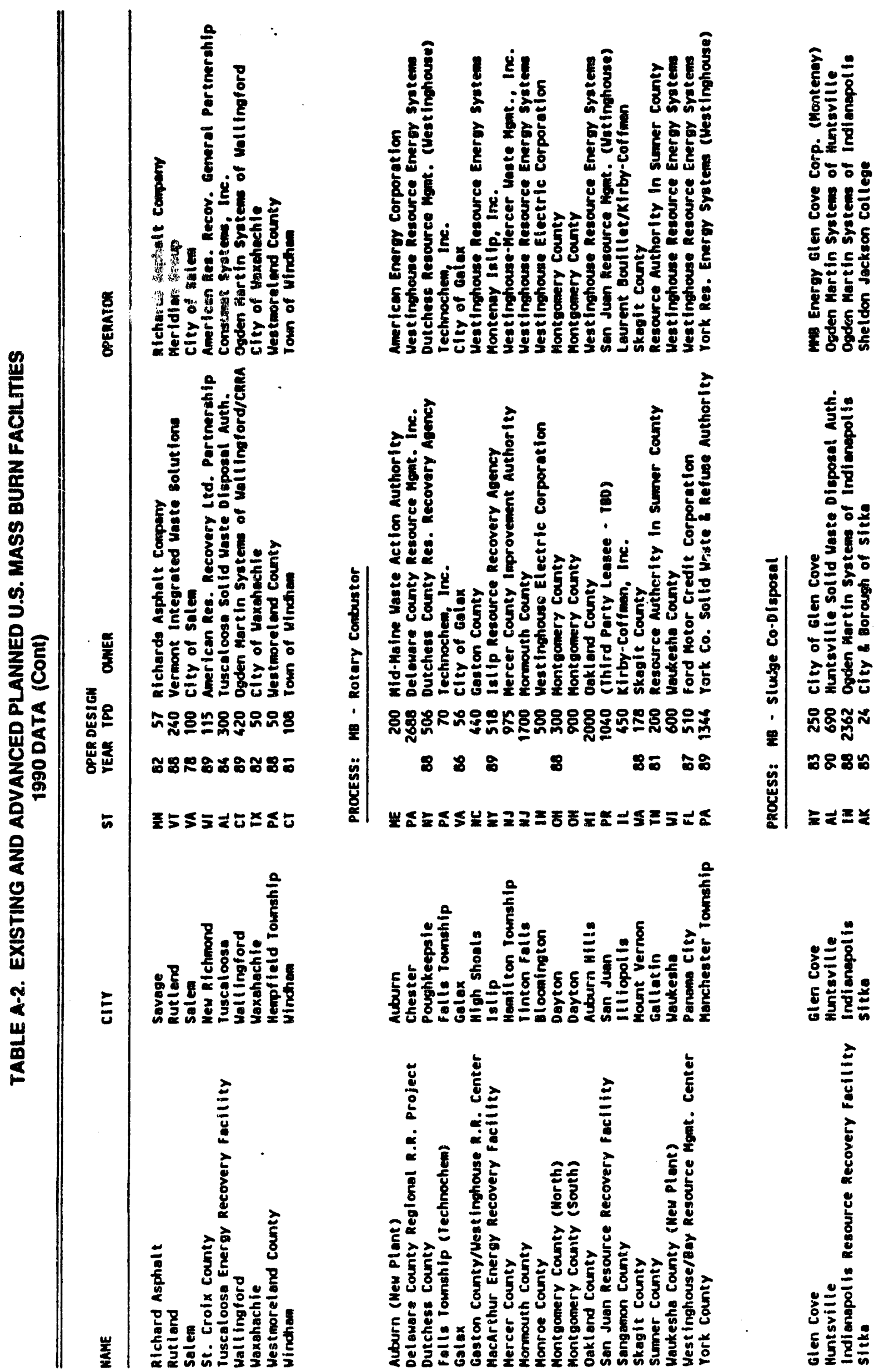




\section{A.2 TECHNOLOGY DESCAIPTION}

Figure A-1 shows a generic flow diegram for a mass bum facilly (799). Eloth fiold-erected and modular systems have the same generul process subsystems - waste storape and foed system, grate system. combustion area and boiler, energy recovery, electricily generation, air pollution control, and ash handling. A comparison of these features for field-erected and shop-fabricated mass bum systems is presented in Teble A-3.

\section{A.2.1 Eleid-Enocted Systems}

Most large mass bum systems utlize a pit and crane system for MSW storage and feed $(275,799)$. In this arrangement, large overhead cranes move MSW from the storage pit to the fumace charging hoppers. The crane-feed system allows for some mixing of the MSW due to the action of the crane. Disadvantages of the pit and crane system are the "last in, first out" operating scheme, higher capltal costs than the tipping floor method, and the difficulty in previewing or sorting the waste prior to feeding (799). A backup crane is nomally provided, since there is no other means of feeding MSW into the system if the crane is inoperable. The charging hoppers typically discharge into the fumace by gravily, although many systems incude a cycling ram at the fumace opening to control the feed rate. A minimum pit storage capacity oi 3 days is recommended to ensure adequate foed material for a 3-day holiday weokend (799).

All successful field erected mass bum plants have either a moving grate in one or several parallel planes, or the less common rotary kiln type of geometry (799). The typical mass bum grate is constructed of several sections which can be horizontal but are usually slightly inclined. MSW is moved along the grate by the combined action of moving grate elements and gravity. Often steps are used abing the grate so that the waste tumbles as it passes, exposing new combustbles to the oxidizing conditions of the fumace, thus improving the material bumout. The multiple grate sections, each usually with its own separate undergrate air system, are the initial grate, often called the drying grate, the buming grate, and the burnout or finishing grate, which discharges the bottom ash usually to a wet quench pit (303). Reciprocating grates are the most frequently used in field erected mass bum units (799). 


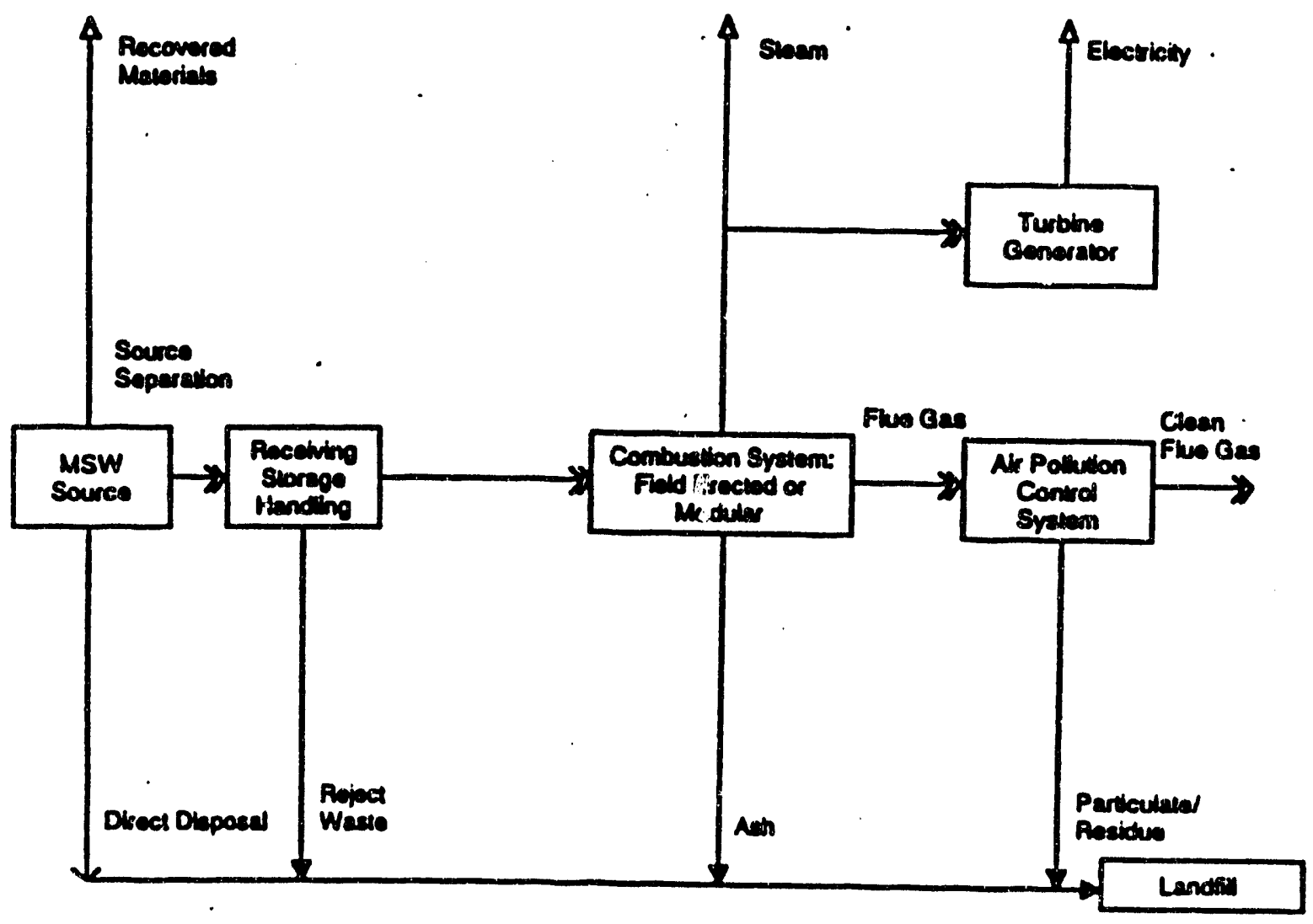

KFY

$\longrightarrow$ Westo Procass Srnam

$\longrightarrow$ Bypass Wasto

$\longrightarrow$ Makutabes Orepes

Pripes and Proceses Peaidu

Flgure A-1. Mass Bum Facilty - Generte Flow Dlagram (799) 


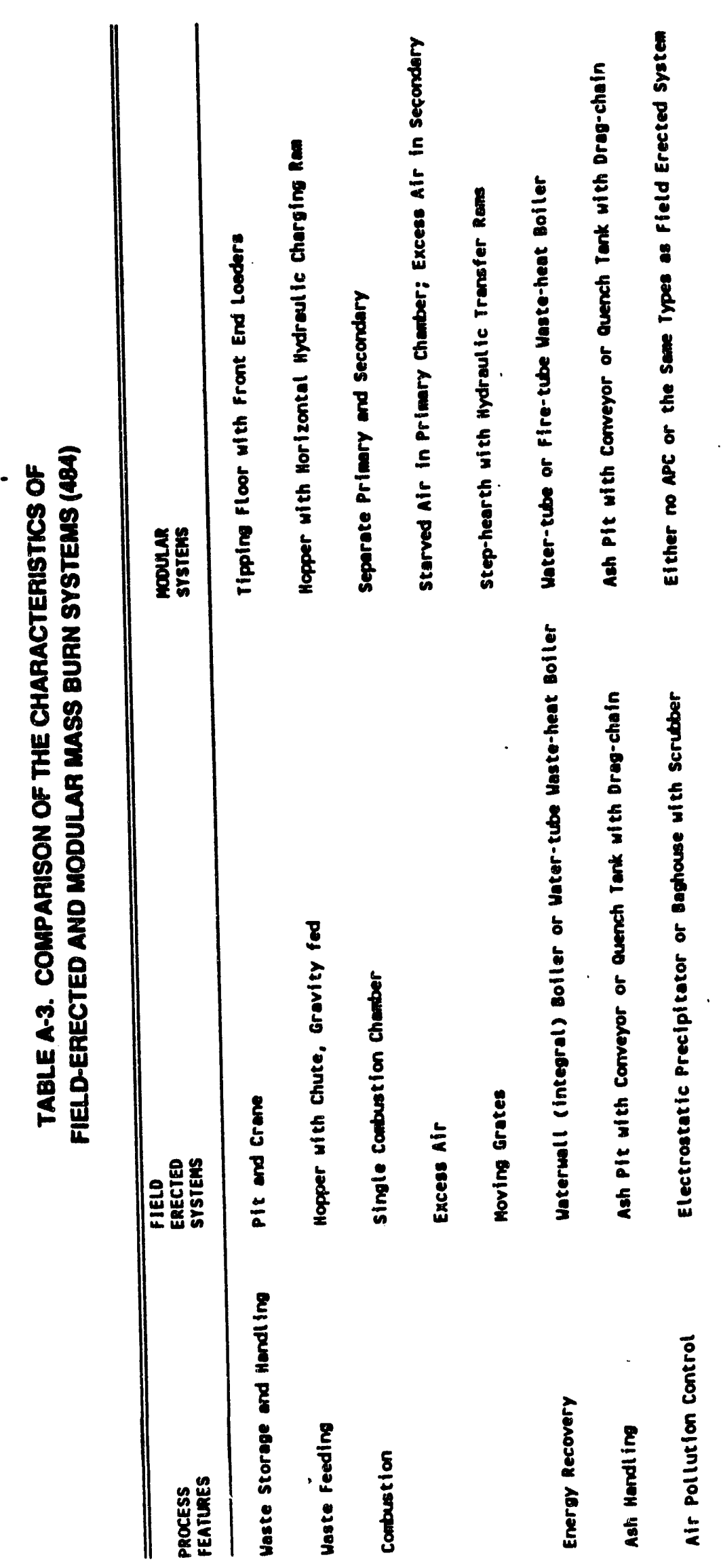


The existing and planned field erected mass bum facilities are listed by grate manufacturer in Attachment 1 to this appendix. The major grate manufacturens are Martin of Germany, Von Poll of Switzerland, and Detroit Stoker of the U.S. Other manufacturers such as VKW, are major suppliers in the European market.

The Martin grate, developed in 1959, has an 18 degree incline, with a reverse action, feeding buming waste undemeath treshly fed material to dy it (2T7). The Von Roll grate was developed in the mid 1960 s and has an 18 degree incline, with stoel grate blocks giving alternate fixed and moving sections. The two foading field erected mass bum tacility system vendors, Ogden Martin and Wheclabrator Environmental Systems, use predominantty Martin and Von Roll grates, respectively. The Von Roll grate technology is also used at two Canadian facilities in Montreal and by Quebec Clty. The Detroll Stoker reciprocating grate (Figure A-2) has most recently been used in the Commerce, Califomia 400 TPD facility.

Other examples of moving grates include: the Dusseldorf roller grate (Figure A-3), developed by Deutsche Babcosk Anlagen in 1960 (277), and distinguished by a design that consists of a series of rollers that tumble the waste at a controlled rate (235); and the DeBartolomeis S.p.A. grate that has altemating fixed and moving stepped reciprocating bars which move at any angle between horizontal and 21 degrees (277).

The other general variety of mass bum grate is the rotary kiln. The refractory-lined rotary kiln, originally developed by Volund, is now available from a few different manufacturers in several configurations. The Westinghouse/O'Connor combustor is the only waterwall version of the rotary kiln; shown in Figure A-4 (799).

The combustion process involves the drying, devolatilization, and ignition of MSW on the grate inside the combustion area in a section referred to as the furnace (402). Controlled air combustion and excess air combustion are the two most prevalent types of combustion methods. Controlled air separates the ignition step by combusting volatilized gases in a chamber separate from where the MSW is dried, volatilized, and tumed to char. Excess air combustion completes drying, devolatilization, and ignition in the same chamber, each step of which is usually viewed as a stage on the moving grate on which the waste rests (472). Gas temperatures in the fumace zone of a mass burn facility typically exceed 1,800 degrees $F(402)$. 


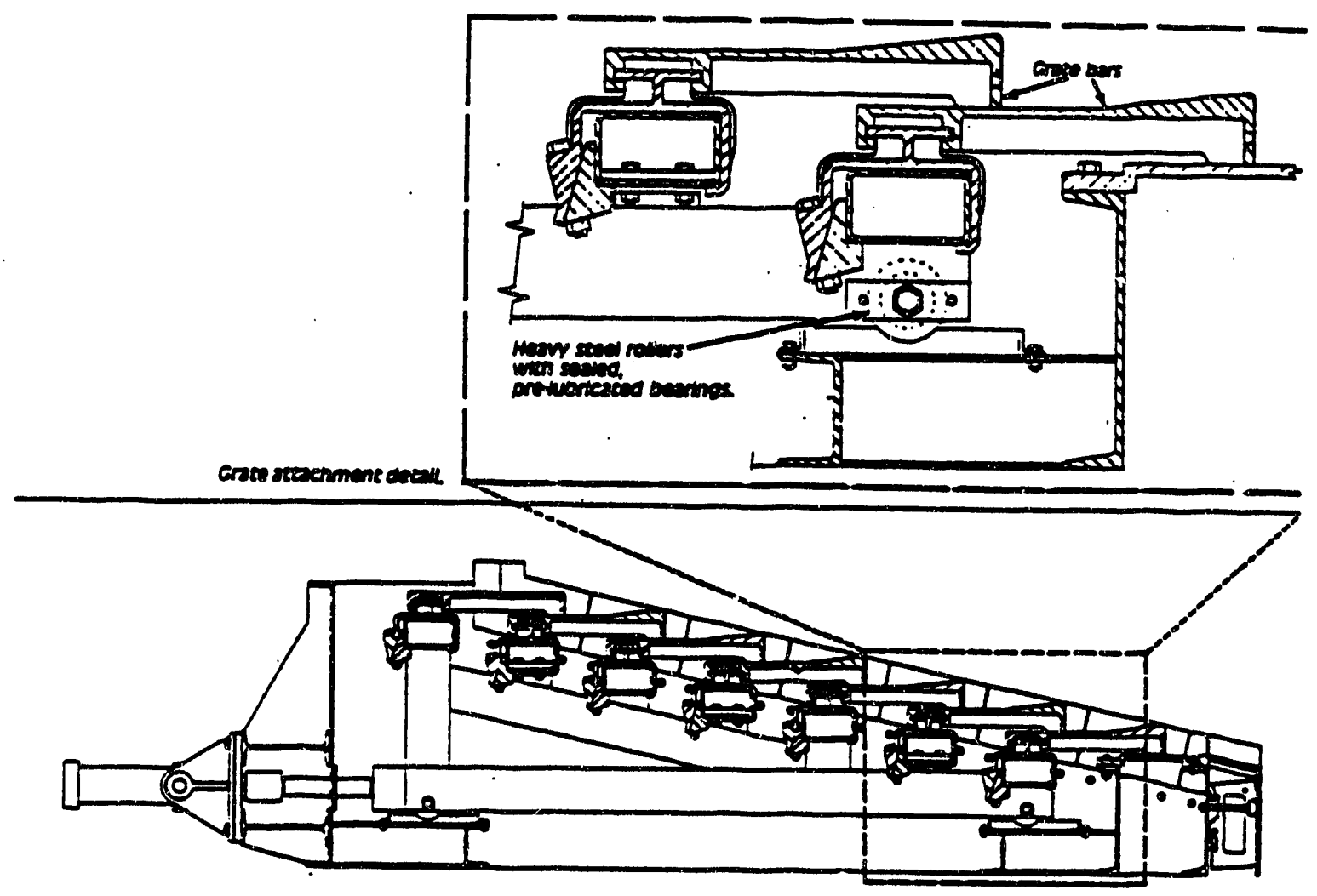

Figure A-2. Detrolt Stoker Reclprocating Grate Stoker (472)

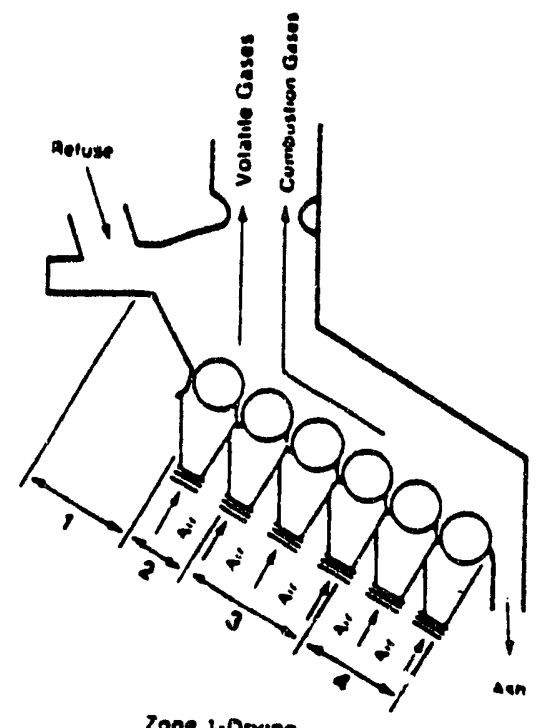

Zone 1. Orving

Zone 2-Onatwlation

zone s-combustoon

Zone e-Burnoul

Flgure A-3. Deutsche-Babcock Dusseldorf Roller Grate (472) 


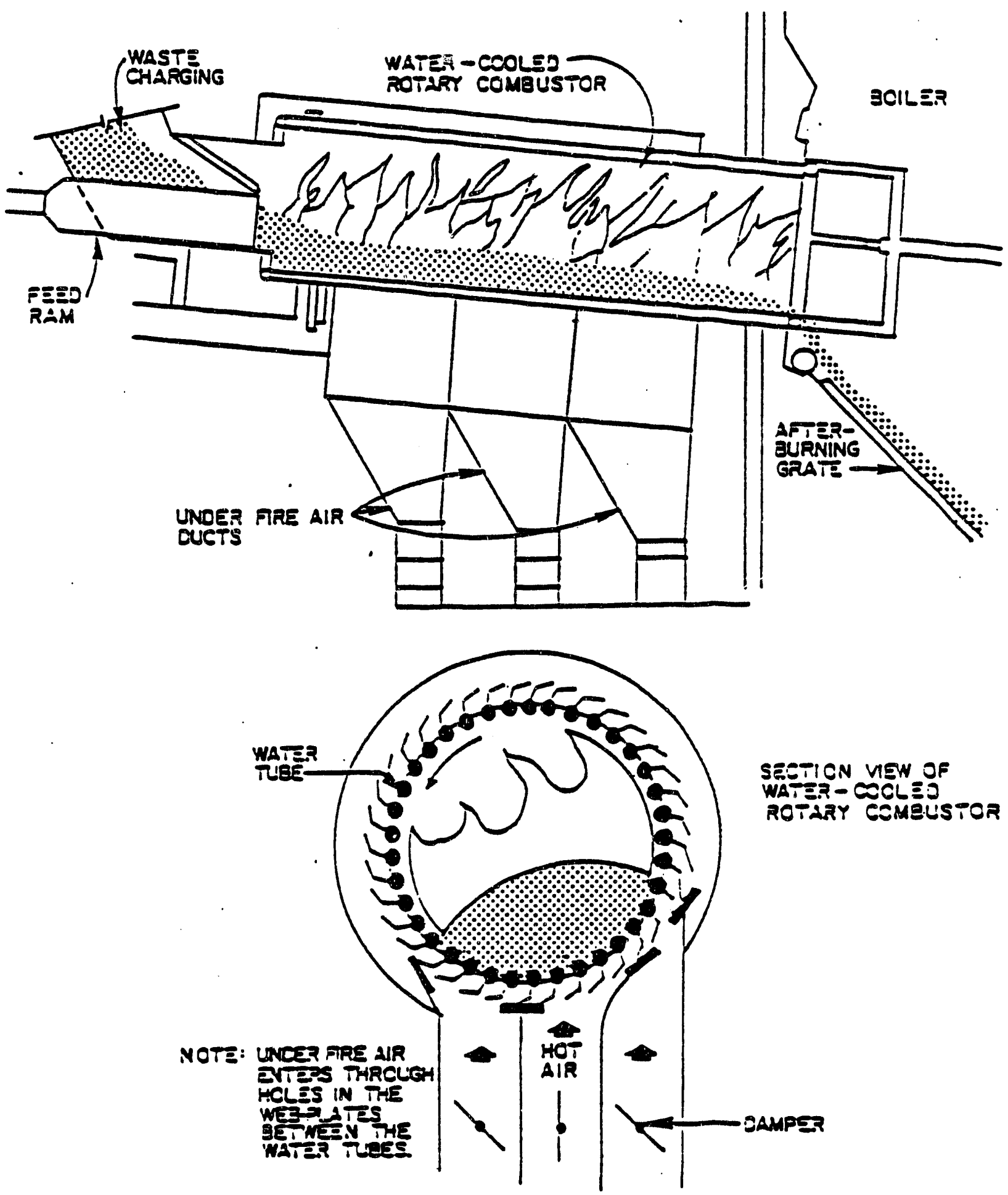

Figure A-4. Waterwall Rotary Combustor (799) 
There are two distinct designs for the combustion area of a field erected system: a refractory-lined fumace chamber with a separate watenwall boiler, referred to as a "refractory systern"; and a refractory-lined waterwall fumace and boller, referred to as a waterwall system" (799). Babcock \& Wilcox, Foster-Wheeler, Rlley Stoker, and Zum Inclustries are the major boller manufacturers in the U.S. Attachment 2 lists all field-erected mass bum tacilties by boiler manufacturer.

\section{A.2.1.1 Refremon Syatems}

Refractory-lined tumaces and rotary kilns are equipped wh a waste heat boller bcated downstream of the fumace chamber. The fumaces are lined with a refractory coating such as silicon carbide to protect subsurfaces from corrosive gases inside the turnace. Siticon carbide, often in a tile form and grouted in place, is applied with a calcium bonding agent over carbon steol studs (120, 472). The fact that refractory fumaces can handle bw quality fuels and still maintain adequate combustion temperatures attests to their use in a variety of applications. However, the enery, recovery from a refractory furnace is 3 to 10 percent lower in efficiency than that from a waterwall due to the protective refractory covering that limits the heat absorbing quality of the fumace. As a result, a very large furnace volume per Btu of energy release is needed. Auxiliary fuel bumers are typically provided to supplement the main fuel in the everit that the fuel is extremely wet or $n$ the supply is intemupted. These burners also will fire to maintain the combustion temperature at about 1,800 degrees $F$ or above; the temperatures considered necessary to comtrol dioxinfuran emissions (402).

The operating conditions in the combustion area that can be controlled include the MSW feed rate, the oxygen concentration and the temperature within the combustion zones, the auxiliary fuel firing rate, and the fuel residence time within the combustor. It is important to constantly monitor the operating conditions of the incinerator because of the highly variable composition and heat content of MSW. Figure A-5 shows a typical refractory lined combustor. 


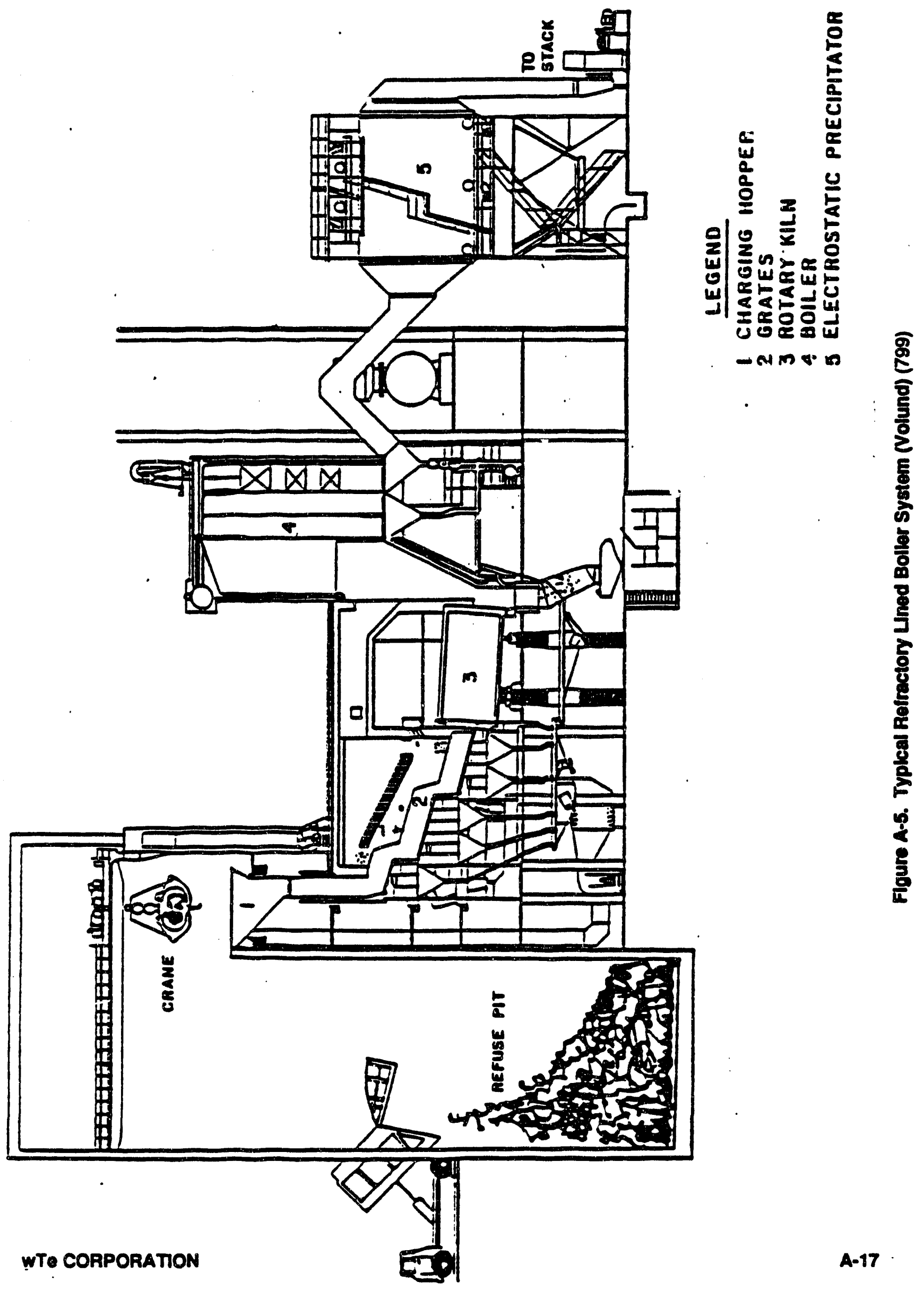




\section{A.2.12 Whatenall Systeme}

Watenwall MSW incinerators are becoming more common than refractory-lined combustors because of their improved hest recovery capabiltios (471). Watenwall units consist of a fumace-boller combination constructed with water tube membrane walls that allow the heat from the combustion process to be transferred to the water inside the tubes. The water cooled walls minimize slagging by absorbing some radiant enerey. Many of the present-day waterwall fumaces have a refractory covering on the lower portion of the tube walls as protection against csirosion and erosion, blurring the distinction between watenwall and refractory fumaces (275). Generally, watenwall fumaces are limited to fiold erected mass burn systerns. A typical watenwall boller system is shown in Fioure A-6.

\section{A.2.2 Modular Syertem}

Modular plants typically use tipping floors and wheel loaders for infeed to their fumaces, although some have used the ph and overhead crane approach (799). Sitka, Alaska is an example of a modular system using the pit and crane approach (86). The tipping fbor method affords better waste sorting and removal, while simplifying building and foundation design. The principal disadvantages of this storage method are the large building area required to provide sufficient waste storage and the abuse absorbed by the floor and bader (799).

The grate systems used by modular mass bum facilities are primarily the products of domestic companies. The grate system varies from vendor to vendor, some using variations of a moving hearth or reciprocating grate system, others using transfer rams to sequentially move the waste through the fumace. Most vendors manufacture their own grate system as part of the modular unit.

Within the modular MWC technology there are two sub-categories: the starved air system and the excess air system. The starved air modular uses a substoichiometric condition in the primary fumace, and superstoichiometric conditions in the secondary furnace. The objestive of this system is to achieve combustion quiescence in the primary chamber to minimize particulate carryover, and therefore minimize air pollution control (APC) requirements. A substoichiometric design allows low turbulence, low temperature, and a low combustion air flux, all of which assist with the goal of quiescerice. The excess air modular system also utilizes two (or more) fumace chambers, but the primary chamber is subject to superstoichiometric conditions in which excess combustion air is provided to maximize combustion. 


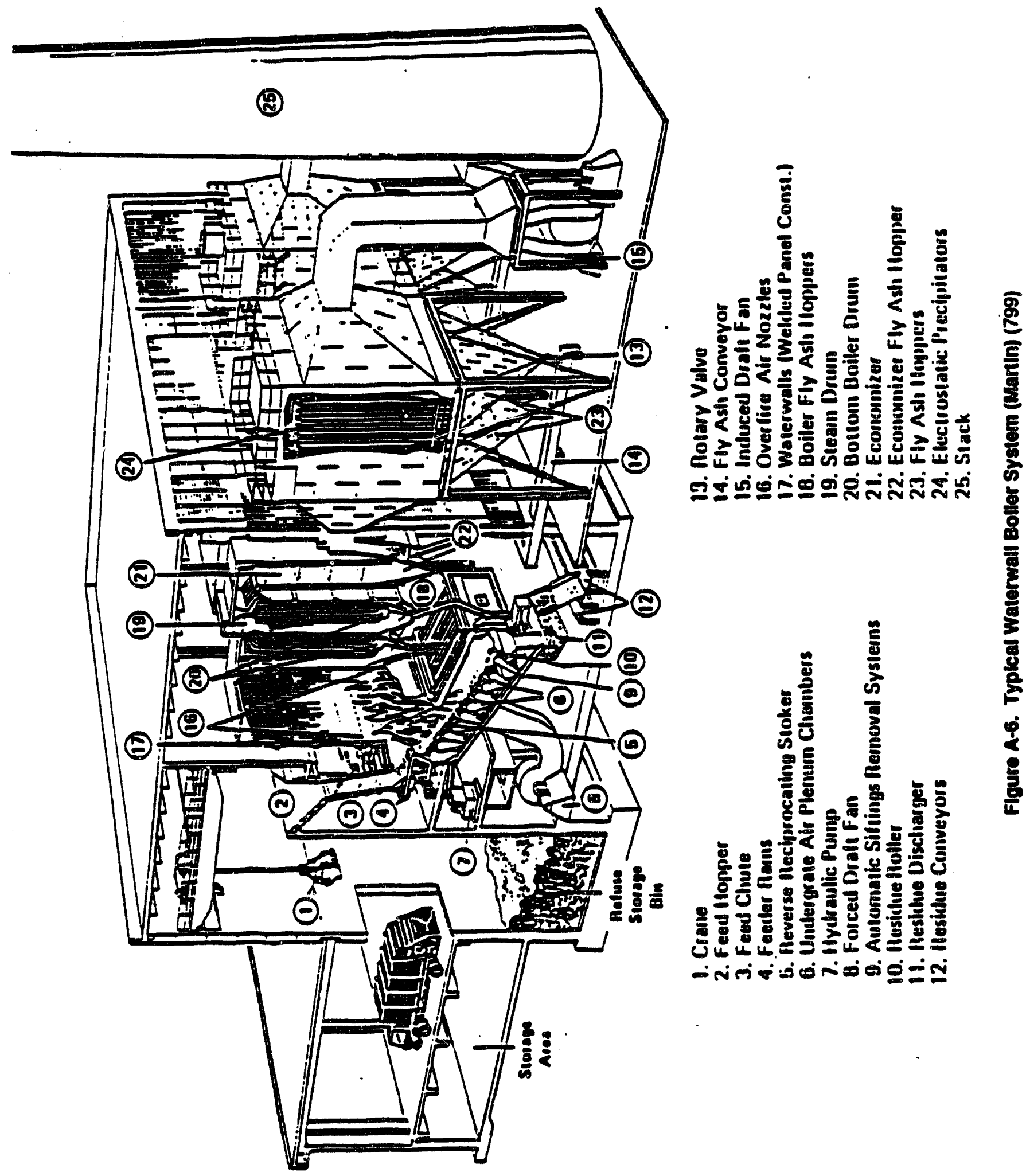


Regardless of type, the primary and secondary combustion chambers are usually refractory lined (303). Waste is fed into the primary chamber onty, and ash is continuousty removed from the primary chamber. The excess air type uses up to 200 percent excess air in ts primary chamber. This means that uses three times the amoun of air theoretically needed to consume the combustible fraction of the waste. This large amount of air simply pasees through the fumace, recovery boiler, and air pollution control system, leaving the system via the stack at an elovated temperature, causing considerable thermal losses and a recuced boller efficiency.

The starved, or controlled air ippe may be substoichiometric in the primary combustion chamber, thus creating weakly combustible gases which are binted and consumed in the secondary chamber. The secondary chamber accepts products of complote or partial combustion and entrained ash particulate from the primary chamber. Thus, the primary chamber temperature is 1500 to 1800 degrees $F$, while the secondary chamber operates at 1800 to 2000 degrees F. In the secondary chamber the gases are treated to high turbulence, additional residence time at an elevated terncerature, and thoroughly oxidizing conditions. The starved air tectnology has an overall excess air of 140 to 170 percent, which is significantly lower than the excess air modular approach, but still much higher than a single fumace, large-scale mass bum system. The fully oxidized products of combustion leave the secondary chamber and proceod typically through a waste heat boiler, and then through an air pollution control (APC) device.

One characteristic of most modular systems is the discontinuous, quasi-batch feeding arrangement. This causes some problems with combustion regularity and emissions. Once the waste is in the fumace, it is advanced mechanically in a fairty regular fashion by an active furnace floor. Because many of the modulars operate substoichiometrically in the primary chamber, the carbon bumout of their solids is naturally poorer than in a fully oxidizing furnace. The average wet ash residue is 27 percent of the MSW feed stream for modulars, whereas the average ash residue for all MWCs is 23 percent (387).

In modular incinerators, the fumaces are usually completely uncooled. All heat transfer takes place far downstream of the combustion zone, so no protection is required for the heat transfer surface. However, due to the large overall excess air used in moduiars, the gas temperature is low entering the waste heat boiler. Thus, considerably more heat transfer surface area is required to remove the same amount of heat from a modular system compared to the high-temperature, fumace-cooled field erected mass bum combustion system. Examples of modular system designs are shown in Figures A-7 and A-8. 


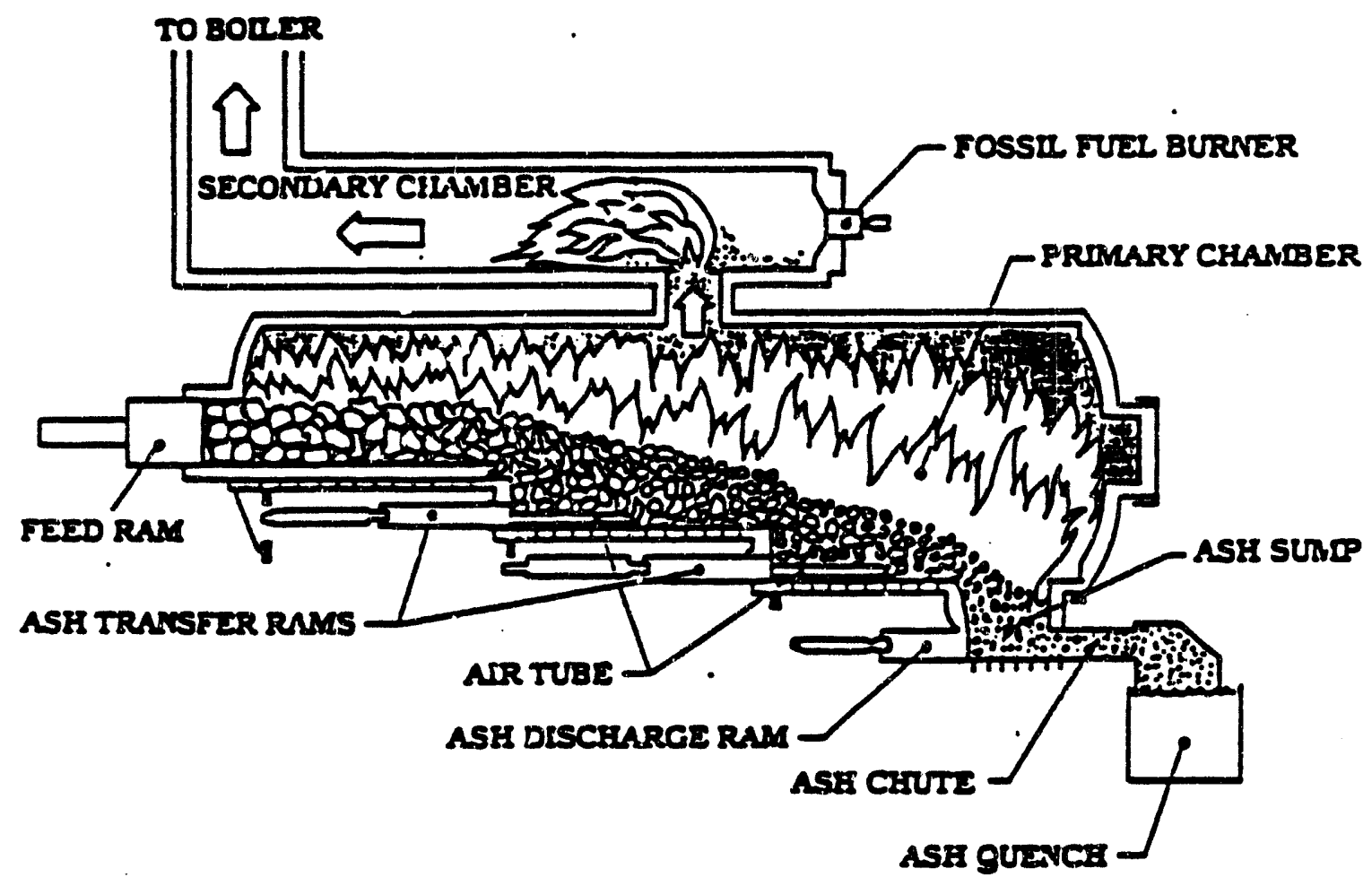

Floure A-7. Moctutar Mases Burn System - Consumat (799)

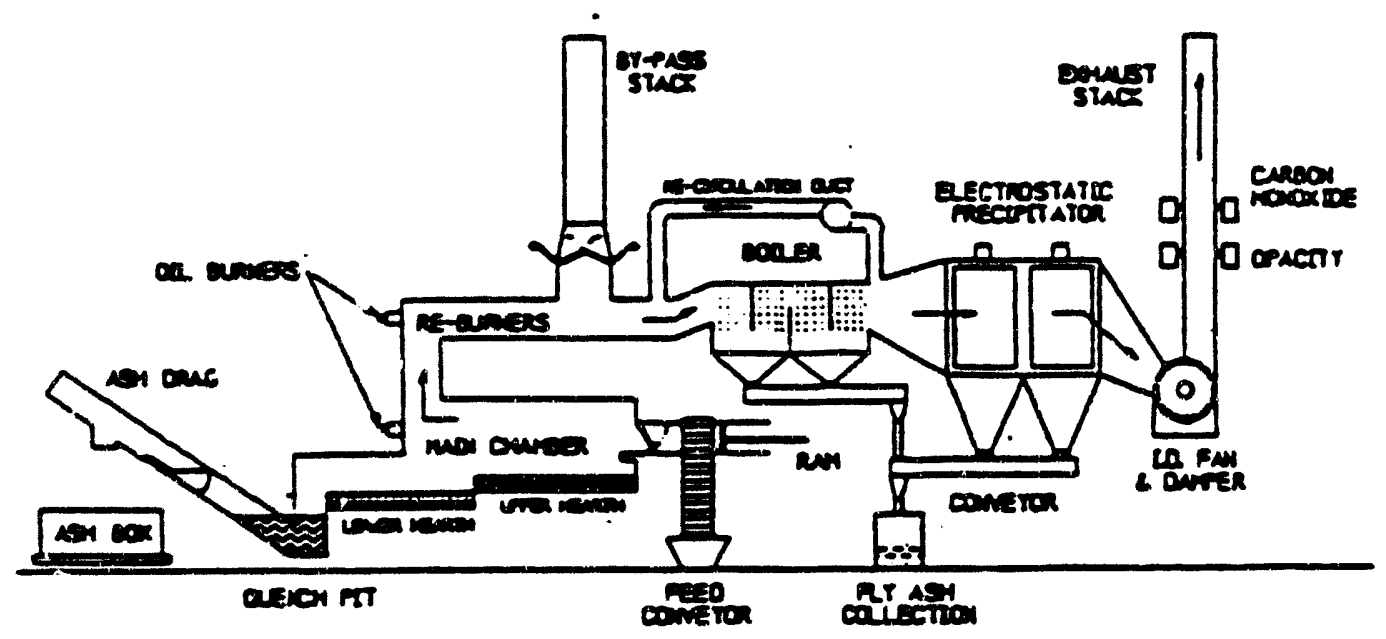

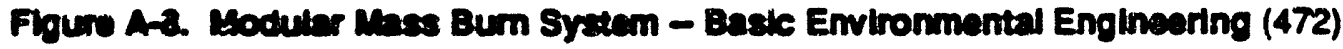




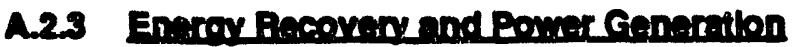

Energy recovered from MSW is typically in the form of steam. The steam proctuced may be used internally in turbine drives on plant equipment such as induced draft fans and boiler feed pumps, for district heating or cooling, for off-sile industrial process use, to drive a turbine generator for electrictly production, or a combination of these options (89). The simultaneous production from one fuel source of two energy forms, normally steam and electricity in wasto-10-energy facilties, is known as cogeneration. In situations where a steam market exists, $h$ is highty desirable to cogenerate steam and tectricty. Such a system will operate at an overall thermal efficiency of up to 2.5 to 3 times that of an electricity-onty system, provided that the exhaust heat can be captured and partially used for thermal energy production (89). Otten a portion of the generated eloctricily is used intemally to power the plant equipment.

Steam produced from the combustion process can be converted into electrical energy in a turbine generator. The most efficient generation of electricity from steam requires the use of high pressure, superheated steam, at a temperature of at least 700 degrees $F(75,89)$. This is because the Btu's of superheated steam can be utilized more efficiently than those of saturated steam (89). However, the majority of MSW-fired power plants are designed for steam at around 650 degrees $F$ in order to reduce boiler corrosion problems (89).

The steam turbine produces shatt power which turns a cenerator, thus producing electricity. Maximum power output per unit of steam flow input can be achieved through the use of a condensing turbine, i.e., one that uses the energy contained in the steam for power generation only. Less conventional and less efficient noncondensing turbines are atso available for specific conditions. Noncondensing turbines exhaust steam at the back end of the turbine for process use or space heating. Fioure A-9 (89) shows the components of a waste-to-energy system with a condensing turbine. Turbines are available in single or multiple stages, with multi-stage units being more efficient (89). Nearty all condensing turbines used in waste-to-energy power production are multi-stage units (89). 


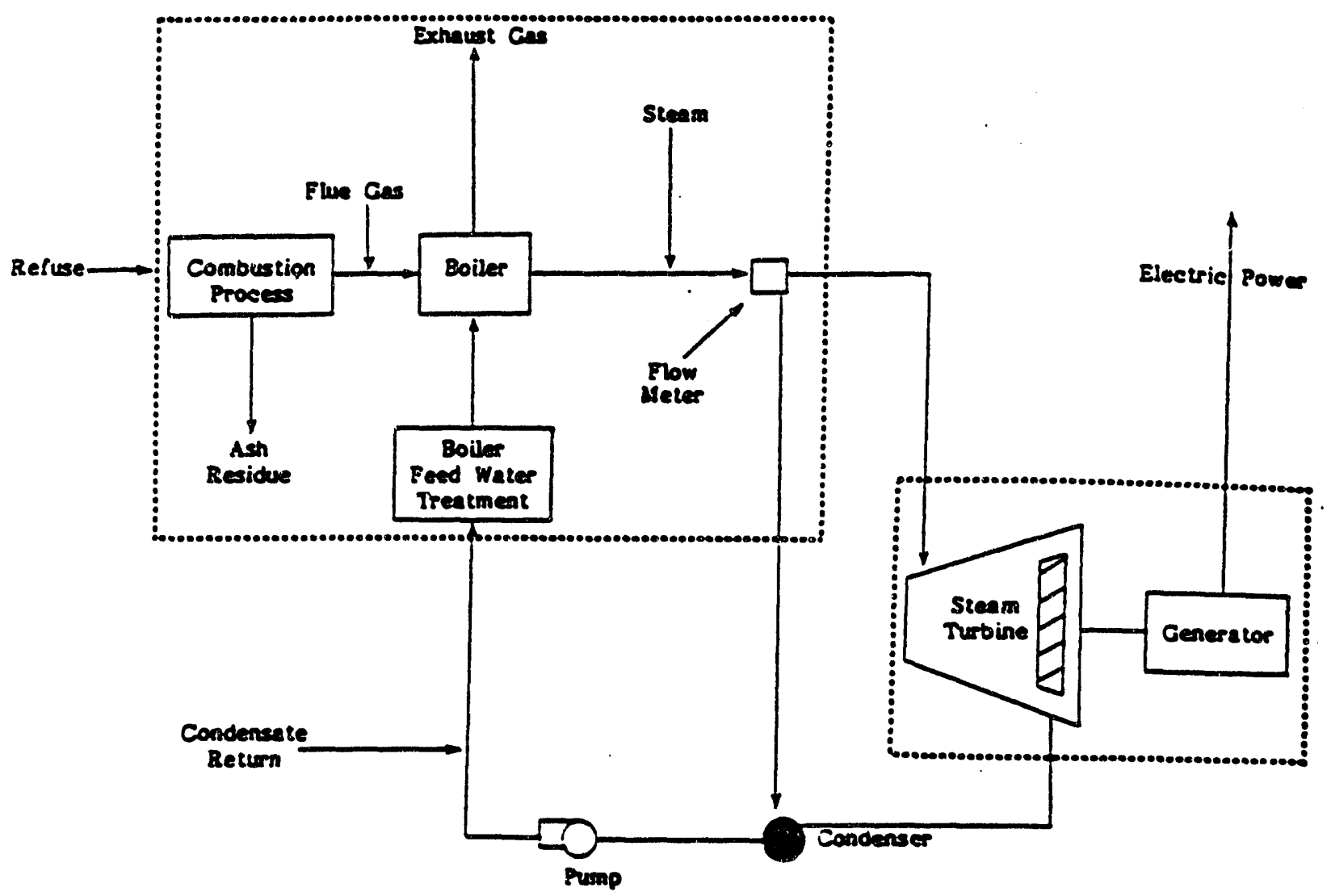

Figure A-9. Basic Componants of a Waste-to-Energy System with a Condensing Turbine (89) 
Two basic turbine types are avallable for MSW cogeneration systems: backpressure and extraction turbines (89). A backpressure turbine exhausts steam at pressures above atmospheric pressure; this steam can be put to further use. An extraction turbine acts as a combination of a backpressure and a condensing turbine. All of the steam is directed into the turbine, and a portion of the steam flow is extracted after passing through some of the turbine blades. The extracted steam can be used for any desired purpose. The remaining steam in the turbine is carried all the way to condensing, thus maximizing electrictly production (89).

The efficiency and cost of steam tubines are stronoly related to size. The larger machines are much more efficient and economical, than the emall turbine-generators which are relatively inefficient and expensive on a pertww basis. The effect of size, as shown in Table A-4, is very dramatic (89).

TABLE A-4. TURBINE GENERATOR EFFICIENCY (89)

$\begin{array}{cc}\text { Size (MW) } & \begin{array}{c}\text { T-G Efficioncy, } \\ \text { Overall }\end{array} \\ & 45-58 \\ 5-1 & 58-65 \\ 1-3 & 65-72 \\ 3-7 & 72-77 \\ 7-15 & 78-81 \\ 20+ & \end{array}$

\section{A.2.4 Besidue Handiling}

The residuse from mass bum systems consists of bottom ash and fly ash. Bottom ash is the material remaining on the grate after combustion and also includes grate siftings, the material that falls through the grate system. Fly ash is the solid materials removed from the flue gas by the air pollution control equipment. Both wet and dry ash systems are available, although wet ash handing is preferred over dry systems (85). 
In a wot ash syetem, bottom ash is dischanged into a water-filled tank for quenching. The ash is removed from the tank by a ram or drag conveyor via an inclined dowatering ramp and transferred to a storage area prior to ultimate disposal most likely in a landifil. Dry ash systems use a chute to store the bottom ash until cooled sufficiently to be removed by a bell conveyor. A water mist can be applied to control dust. Fly ash is collected from the air pollution control equipment and conditioned to minimize dust. The fly ash can be combined with the bottom ash or disposed of separately.

Most modem modular units are equipped with continuous ash removal systems using an arrangement similar to submerged drag chain conveyors (799).

HDR Engineering, Inc. reports that ash from field erected mass bum plants is 15 to 25 percent by dry weight of the as-received MSW and is approximately 5 to 10 percent by volume. The ash has a moisture content of about 25 percent and is 20 to 35 percent by wet weight of the as-received MSW (799). Govemment Advisory Associates (387) reports the average wet ash residue to be 24 percent of the MSW mass for mass burn facilities. For comparison purposes, average wet ash residue is 13 percent of MSW on a mass basis for an RDF MWC (387).

The disposal, treatment, and utilization of ash is discussed in Section A.5.3.

\section{A.2.5 Alr Pollution Control Systeme}

On February 11, 1991, the U.S. Environmental Protection Agency issued revised performance standards and emission guidelines for new and existing MWC facilities (561). These New Source Performance Standards (NSPS) limit the following MWC emissions:

- Organics - measured as dioxins and furans

- Metals - measured as particulate matter

- Acid Gases - measured as sulfur dioxide and $\mathrm{HCl}$

- Nitrogen Oxides (NOX)

The NSPS for both new and existing facilties are provided in Table A-5. The standands for new facilities only apply if the capacity is over 250 TPD. Standards for facilities 250 TPD or less are required by the Clean Air Act to be promulgated within two years. Further, the Clean Air Act requires that NSPS be revised within one year. These revisions will include standards for mercury, cadmium, and lead. 
The EPA has selected various techniques, referred to as Best Demonstrated Technology (BDT), that serve as the basis for the establishment of the standards. A BDT has been specilied for each MWC class for motals, acid gas and NOx control. These BDTs are indicated in Table A-5. For now MWCs larger than 250 TPD, BDT is defined as good combustion practice coupled with a spray dryer absorber followed by a fabric fiter for organics, acid gas and metals control. The BDT for NOx control is defined as selective noncatalytic recuction.

The revisions to these standards mandated by the Clean Air Act will reflect the Maximum Achievable Control Technology (MACT). MACT will require new facilties to utilize technology that is no less stringent than the best performing similar uni.

Table A-6 presents data on the numbers and percentages of all planned and existing field erected MWC facilities using each of the major air pollution control (APC) systems (387). Similar data is provided for modular facilities in Table A-7.

Dry scrubbers with fabric filters is the ovenwhelming choice of planned facilities, with 75 percent of the modular facilities and 94 percent of field erected facilities intending to use this technology. ESPs are installed on 46 percent of existing field erected mass bum facilities; 52 percent are equipped with ory scrubbers. Figure A-10 shows a typical dry scrubberkiabric filter air pollution control system (223).

None of the planned modular facilities intend to include NOX control, but 59 percent of the planned field erected units do plan on including this technology. Three lacilties in southem Califomia have incorporated NOx controls in their air pollution control systems: Commerce, Stanislaus County, and Long Beach (SERRF). 
TABLE A-5. 1991 PERFORMANCE STANDARDS AND EMISSION

GUIDELNES FOR NEW AND EXISTWG MWC FACULTIES (561)

\begin{tabular}{|c|c|c|c|}
\hline & \multirow{2}{*}{$\begin{array}{l}\text { NEW } \\
\text { FACILITIES } \\
\text { OVER } 250 \text { TPD }\end{array}$} & \multicolumn{2}{|c|}{ EXISTING FACIILITIES } \\
\hline & & $\begin{array}{l}\text { OVER } \\
1100 \text { TPD }\end{array}$ & $\begin{array}{l}\text { LESS THAN } \\
1100 \text { TPD }\end{array}$ \\
\hline \multicolumn{4}{|l|}{ Good Combustion Practice } \\
\hline Steam Load (a) & $110 \%$ & $110 \%$ & $110 \%$ \\
\hline PM Control Iniet Temp (b) & 30 & 30 & 30 \\
\hline CO (ppmn 24 Hr Average) & 150 & 200 & 200 \\
\hline \multicolumn{4}{|l|}{ MWC Organics } \\
\hline Dioxin/Furan (ng/dscm) & 30 & 60 & 250 \\
\hline \multicolumn{4}{|l|}{ MWC Motals } \\
\hline PM (mg/dscm) & 34 & 34 & 69 \\
\hline Opacity (\% - 6 min avg) & $10 \%$ & $10 \%$ & $10 \%$ \\
\hline Basis (BDT) & FF & ESP & ESP \\
\hline \multicolumn{4}{|l|}{ Acid Gases (higher of:) } \\
\hline $\mathrm{SO}_{2}$ (pprmv) or: & 30 & 30 & 30 \\
\hline $\mathrm{SO}_{2}$ (\% reduction) & $80 \%$ & $70 \%$ & $50 \%$ \\
\hline $\mathrm{HCl}$ (ppmv) or: & 25 & 25 & 25 \\
\hline $\mathrm{HCl}$ (\% reduction) & $95 \%$ & $90 \%$ & $50 \%$ \\
\hline Basis (BDT) & SDAFF & SDAESP & DSI/ESP \\
\hline \multicolumn{4}{|l|}{ Oxides of Nitrogen } \\
\hline NOx (pprnv 24 Hr Avg) & 180 & - & - \\
\hline Basis (BDT) & SNCR & & \\
\hline
\end{tabular}

(a) Expressed as a percent of MCR as measured during the most recent dioxinfuran compliance test.

(b) Expressed as maximum allowable deviation (degrees F) above a site specific particulate matter (PM) control device inlet temperature as established during the most recent dioxinfiuran compliance test.

(c) FF = Fabric Fitter, SDA = spray dyer absorber (dry scrubber), ESP = electrostatic precipltator, DSI = duct sorbent injection, SNCR = selective noncatalytic reduction. 
TABLE A-6. APC SYSTEMS FOR FIELD ERECTED FACILTIES (387)

\begin{tabular}{|c|c|c|}
\hline APC Equipment & Planned & Existing \\
\hline $\begin{array}{l}\text { Electrostatic Precipitator (ESP) } \\
\text { ESP with Dry Scrubber }\end{array}$ & $1(3 \%)$ & $\begin{array}{l}23(33 \%) \\
9(13 \%)\end{array}$ \\
\hline $\begin{array}{l}\text { Dry Scrubbers with Fabric Filler } \\
\text { Dry Scrubbers, Fabric Fiter \& NOx Control }\end{array}$ & $\begin{array}{l}12(35 \%) \\
20(59 \%)\end{array}$ & $\begin{array}{l}30(43 \%) \\
6(9 \%)\end{array}$ \\
\hline Baghouse & & $1(1 \%)$ \\
\hline Wet Scrubber with Baghouse & & $1(1 \%)$ \\
\hline \multirow[t]{2}{*}{ Not Determined } & $1(3 \%)$ & \\
\hline & $\overline{34(100 \%)}$ & $\overline{70(100 \%)}$ \\
\hline
\end{tabular}

TABLE A-7. APC SYSTEMS FOR MODULAR FACILTIES (387)

\begin{tabular}{|c|c|c|}
\hline ARC Equipment & Planned & Existing \\
\hline $\begin{array}{l}\text { Electrostatic Precipltator (ESP) } \\
\text { ESP with Two Chamber Fumace } \\
\text { ESP with Dry Scrubber } \\
\text { ESP with Wet Scrubber }\end{array}$ & & $\begin{array}{l}13(26 \%) \\
6(12 \%) \\
1(2 \%) \\
2(4 \%)\end{array}$ \\
\hline $\begin{array}{l}\text { Dry Scrubber } \\
\text { Dry Scrubbers with Fabric Filier } \\
\text { Dry Scrubbers, Fabric Fitter \& NOx Control }\end{array}$ & $3(75 \%)$ & $\begin{array}{l}1(2 \%) \\
6(12 \%) \\
1(2 \%)\end{array}$ \\
\hline Baghouse with Two Chamber Fumace & & $1(2 \%)$ \\
\hline Wet Scrubber with Baghouse & & $1(2 \%)$ \\
\hline $\begin{array}{l}\text { Two Chamber Fumace } \\
\text { Two Chamber Fumace with Wet Scrubber } \\
\text { Two Chamber Fumace with Cyclone }\end{array}$ & & $\begin{array}{l}11(22 \%) \\
2(4 \%) \\
1(2 \%)\end{array}$ \\
\hline Cyclones & & $3(6 \%)$ \\
\hline Wet Scrubber. & & $1(2 \%)$ \\
\hline \multirow[t]{2}{*}{ Not Determined } & $1(25 \%)$ & \\
\hline & $4(100 \%)$ & $50(100 \%)$ \\
\hline
\end{tabular}




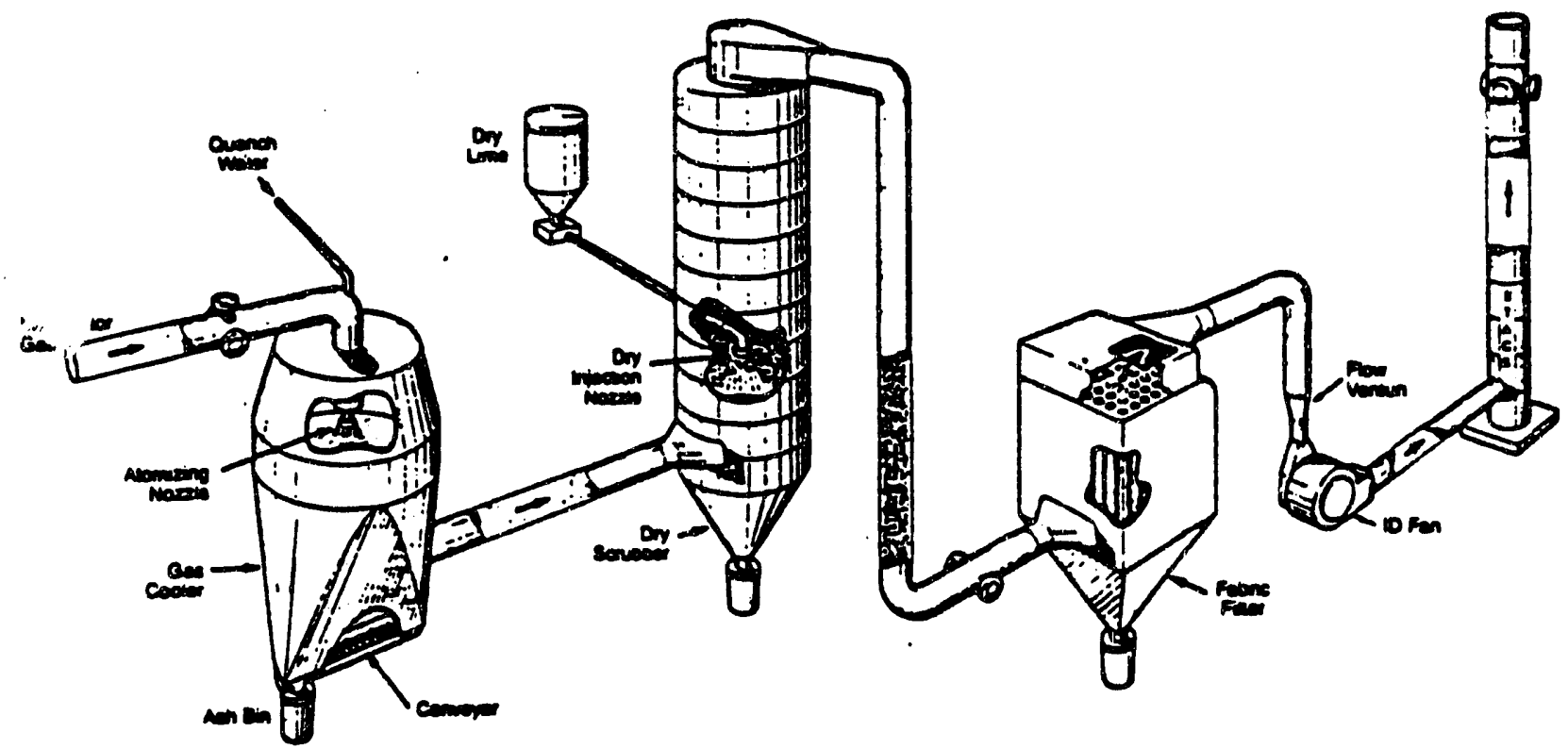

Figure A-10. Componemts of Typlcal Dry Scrubber/Fabric Filter Spray Dryer System (223)

\section{A.2.5.1 Good Combustion Practice}

Good combustion practice (GCP) can be used as a form of APC technology. GCP consists of controlling the amoum and distribution of excess air in the flue gas to ensure there is enough oxygen for complete combustion. Good combustion practice combines the three "T's of combustion - time, temperature, and turbulence, with an adequate supply of oxygen (402). GCP can be effective in controlling both carbon monoxide (CO) and dioxinturan (PCDD/PCDF) emissions by providing the necessary conditions for complete bumout and dioxin destruction. A recent Swedish study on the formation and destruction of dioxins showed that 99.86 percent of the dioxins are destroyed at the normal incineration conditions of 800 to 1100 degrees $C$ for 1 to 2 seconds in a the gas containing 7 percent oxygen (857). This study also sinowed that if the oxygen concentration exceeds 10 percent, significant quantities of dioxins were not destroyed, or were reformed after initial destruction. Further, fumace temperatures less than 800 degrees $C$ result in virtually no dioxin destruction. 
Good combustion practice for field erected mass bum facillitis is as follows (298):

\begin{tabular}{|c|c|}
\hline 0 & 1800 degrees F at hully mixed hoight \\
\hline 0 & Four underfire air zones \\
\hline 0 & Overtire air $=40$ percent of total \\
\hline 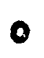 & Overfire air pressure for full penetration \\
\hline o & Auxillary fuel for 1800 degrees F \\
\hline 0 & 6 to 12 porcent $\mathrm{O}_{2}(d y)$ \\
\hline $\mathbf{0}$ & Operating limits of 80 to 110 percent \\
\hline $\mathbf{0}$ & $\mathrm{CO} 50 \mathrm{ppm} \& 12$ percent $\mathrm{CO}_{2}$ \\
\hline
\end{tabular}

GCP for staned air modular MWCs is the same as for mass bum facilities except for the following (298):

$$
\begin{aligned}
& \text { Overfire air }=80 \text { percent of total } \\
& \text { - } 6 \text { to } 12 \text { percent } \mathrm{O}_{2} \text { (dry) }
\end{aligned}
$$

Combustion control can have considerable effectiveness for NOx reduction. Minimal excess air or even conditions that favor chemical reduction at the point of combustion reduce the amount of oxygen available to react with nitrogen and lowers combustion temperatures, tending to lower the NOx emission. The products of combustion from this first zone can be subsequently treated with additional air to achieve reasonable overall stoichiometry while minimizing NOX. This can be effected in a typical MWC by varying the proportions of undergrate and overfire air, resulting in a minimum NOx level of about 100 ppm. Combining Selective Non-Catalytic Reduction with good combustion control can drop the minimum NOx concentration in the flue gas to about 70 ppm. If Selective Catalytic Reduction is also usied, the NOx concentration can be further reduced down to 50 to $60 \mathrm{ppm}$. If a large amount of catalyst is used, a concentration of 10 ppm NOx can be achieved (591).

Data from Nonway (534) show a 30 percent reduction in NOx by increasing primary air and CO above the traditional 60:40 ratio of primary air to overtire air. New Jersey tests have shown that a ratio of $60: 40$ resulted in a NOx concentration of 300 ppm, while a ratio of 80:20 resulted in $225 \mathrm{ppm}$ with no ill effects on CO or opacity (534). 


\section{A.2.5.2 APCEquipment}

Air pollution control equipment for MWCs can be classified according to the pollutant they are designed to control or according to their operating principals (367). vdividual control equipment is usually installed in series to effect a reduction in the number and amourt of pollutants, as indicated above. Brief descriptions of the APC equipment noted in Tables A-6 through A-8 are provided below.

A.2.5.2.1 Panticulate Matter (PM) Comtmol. The electrostatic precipltator can be used alone for particulate matter capture, or following a spray dryer for acid gas removal. Newer ESPs have four or five fields, or sets of electrodes and plates in series, through which the flue gas flow. The fabric fitter (FF) has boen designated as Best Demonstrated Technology for now MWCs. Fabric filters can be classified according to the method of cleaning the bags: shake/deflate, reverse air, and pulse-jet (533); as applied to MWCs, the majority are the pulse-jet or reverse air types. When used in conjunction with an acid gas control device, fabric filters can achieve greater than $99 \%$ removal of particulate matter (303).

A centritugal separator (cyclone) can be used for low efficiency large-sized particulate capture. The efficiency is poor but the technology is useful as a pre-cleanup device, referred to as a "roughing" cyclone.

\section{A.2.5.2.2 Acld Gas control. Duct sorbert injection (DSI) involves the injection of a dry,} chemically active alkali sorbent into the furnace breeching at some point downstream of the fumace and upstream of the particulate control device (preferably a FF). Various removal efficiencies for DSI units have been reported: Kuykendal (303) notes typical removal of 60 to $95 \% \mathrm{HCl}$, and 40 to $70 \%$ for $\mathrm{SO}_{2}$; Bma (370) notes that a DSI/FF system results in 90 to $95 \% \mathrm{HCl}$ capture and 75 to $80 \% \mathrm{SO}_{2}$. Using hydrated lime as a sorbent, $\mathrm{SO}_{2}$ removal is optimized at 1750 degrees $\mathrm{F}$ whereas $\mathrm{HCl}$ and $\mathrm{HF}$ capture is best at 800 degrees $F$. Thus, multiple injection points for the sorbent are appropriate. As an example, Katy-Seghers' 400-TPD Davis County, Utah plant utilizes an ESP and dry hydrated lime injection at three points in the boiler, the tumace breech, between the superheater and convective section, and between the convective section and economizer. The result is $70 \% \mathrm{HCl}$ capture and $80 \% \mathrm{SO}_{2}$ capture with 2.45 stoichiometry, which is $20 \mathrm{lb}$ limenon MSW. The particulate emission is also low, at 0.015 gr/DSCF.

Fumace sorbent injection (FSI) is similar to DSI except that the sorbent is injected directly into the furnace section of the combustor (303). Removal of $90 \% \mathrm{HCl}$ requires a very high stoichiometric ratio (greater than $5: 1$ ) because the lime- $\mathrm{HCl}$ reaction is hindered by the high fumace temperatures (27). 
Combinations of FSI and DSI are often more economical than ellher mothod used alone, because a high temperature favors the $\mathrm{SO}_{2}$ reection, and a low temperature favors $\mathrm{HCl}$. Using hydrated lime and 2.45 stoichiometry with an ESP only, this combined approach can capture $70 \% \mathrm{HCl}$ and $80 \% \mathrm{SO}_{2}$ if injoction of lime is at three points: fumace breech, between the superheater and convective section, and between the convective section and economizer (26).

The spray dryer absorber (SDA), also called ory scrubber absorber (DSA), involves the distribution of a chemically active, sturried sorbent into the the gas. The temperature of the flue gas causes evaporation of the stury's water, resulting in dry conditions downstream of the scrubber. The sorbent reactions provide very high removal efficiencies of $99 \% \mathrm{HCl}, 95 \% \mathrm{SO}_{2}, 99 \% \mathrm{SO}_{3}$, and $95 \%$ HF. The method is abo effective for dioxins and volatile metals (367). Semi-dy or wet alkali treatment followed by a fabric fitter can eliminate $99 \%$ of $\mathrm{HCl}$, total solid particulates (TSP), and other micro-pollutants (282). For mercury $(\mathrm{Hg})$ control, the addition of small amounts of activated carbon or sodium sulfide upstream of SDA can result in greater than $90 \%$ capture (367). An $\mathrm{Hg}$ capture rate of $90 \%$ is possible with SDAFF alone, or $351070 \%$ with SDAESP (370).

Combinations of DSI and SDA provide another effective approach for dioxin. $\mathrm{Hg}$, and even NOx control. This involves the injection of powered dry additive up or downstream of the SDA. NOx removal is 41 to $53 \%$, and $\mathrm{Hg}$ capture is 91 to $95 \%$ (31). Use of the SDAFF technology can achieve compliance with the New Source Performance Standards for $\mathrm{HCl}, \mathrm{SO}_{2}, \mathrm{CDD} / \mathrm{CDF}$, and TSP (28).

Wet scrubbing can use water only for capture of particulate matter and volatile metals, or it can be chemically active for acid gas control and particulate capture. Because wet scrubbers abne are not adequately effective in removing particulates, a typical wet scrubber installation consists of two stages of wet scrubbing located downstream of an ESP (367). The first stage (the venturi stage) is for $\mathrm{HCl}$ removal and the second stage (absorber stage) is for $\mathrm{SO}_{2}$ removal. A wet scrubber following particulate control can result in more than $90 \%$ mercury removal (367). Additional removal of submicron particles and metallic vapors can be achieved by using a heat exchangar downstream of the wet scrubber.

The Japanese have developed a wet scrubber system in which a liquid chelating agent and cupric chloride are injected for the absorption of the atomic mercury contained in the flue gas (532). This system has been shown to result in greater than $90 \% \mathrm{Hg}$ removal. Another Japanese wet scnubber system incorporates sodium hypochlorite injection at a concentration of several tens of ppm to form $\mathrm{HgCl}_{2}$ (532). This system can result in 90 to $95 \%$ mercury capture.

wTO CORPORATION 
The following are the major advantages and disadvantages of wet scrubbing systems (367):

Advantages

- Inexpensive to install and require a relatively small area,

- Can achiove very high removal efficiencies for acid gases (> 99 percent for $\mathrm{HCl}$ and > 95 percent for $\mathrm{SO}_{2}$.)

- Capable of high removal efficiencies for many volatile trace compounds, and

- Require the lowest reagent stoichiometry (1.0 to 1.2) of any of the alternatives.

Disadvantages

- Produce a wet effluent which requires additional complex treatment prior to disposal,

- Are more prone to corrosion problems and may require expensive materials of construction, and

- Have historically experienced more operating problems and higher maintenance requirements than the altematives.

A.2.5.2.3 NOx Control. Selective catalytic reduction (SCR) uses ammonia (NHa) injection upstream of a catalytic reactor to reduce NOx to nitrogen and water (367). NOx rectuction of 80 to $85 \%$ has been achieved with SCR on a wide range of combustion sources (367). Another estimate places the NOx capture at 80 to $90 \%$ for an $\mathrm{NH}_{3}$ NO ratio of 1 and 5 vppm NH3 slip (or breakthrough) (27). Ammonia slip is the amount of unreacted ammonia remaining in the flue gas after the SCR device. The presence of $\mathrm{HCl}$ can cause the SCR catalyst to fail, and particulate can erode the catalyst. Thus, in order for SCR to function successfully on MSW, the SCR unit must be installed downstream of the acid gas and particulate control systems (367). Because of the thermal losses in the acid gas removal unit, the flue gas must be subsequently reheated to the optimum temperature range for the catalyst. These complex conditions have restricted the application of SCR to MWCs.

Selective non-catalytic reduction (SNCR), also known as "Thermal De-NOx" or "Exxon DeNOx" is a patented, in-fumace technique similar to SCR but requiring no catalyst. The process operates in an optimum temperature range of 1700 to 1900 degrees $F$ where it selectively and economically recuces $\mathrm{NO}$ to $\mathrm{N}_{2}$ (27). This process has been successfully applied to many combustion sources in over 60 commercial installations; however, very few of these are MWCs (77). The Southeast Resource Recovery Facility (SERRF), Long Beach, CA, uses Exxon's Thermal DeNOx system (546), as does the Commerce, CA facility (88). Up to $65 \%$ NOx reduction has been demonstrated for this technology at an 
approximate ammonia to NOx ratio of 2 and down to a 5 ppm ammonia breakthrough (367). Limiled test data from the Stanislaus County, CA, Ogden-Martin facility indicates approximate NOx removal efficiencies from 60 to $72 \%$ using the DeNOx system (34).

\section{A.25.2.4 Tremnology Develogmente}

There are a number of systems in the developmental stage. The electron beam (E-beam) process uses either ammonia or lime to to react with and remove $\mathrm{NOx}$ and $\mathrm{SO}_{2}$ in the presence of a high-intensity electron beam (69). The electron beam provides the activation energy to allow the reaction to occur, eliminating the need for high semperatures. This system apparently has not been demonstrated at a fult-scale MWC facillty.

Natural gas rebuming (rebum) for NOx control has been investigated by Riley-Takuma, IGT, and GRI (535). This pilot study demonstrated that rebum can reduce $\mathrm{CO}$ and hydrocarbons, and result in a 50 to $70 \%$. NOx recuction. In the rebum process, overfire air above the grate is replaced with natural gas mixed with recirculated flue gas. The rebum technology allows reduced overall excess air, which provides an increase in efficiency of 2 percent. Study results showed that a 0.9 second residence time in the rebum zone at a stoichiometric ratio of 0.85 to 0.95 resulted in a 50 percent NOx reduction, and a 1.4 second residence time resulted in a 70 percent NOx recuction. Carbon monoxide, although a problem with flue gas recirculation abne, was not a problem with the rebum process.

Another method of NOx control is urea injection. This method has been demonstrated on full scale MWCs both in Europe and the U.S. (367). Urea has an advantage over ammonia in that it is not considered to be a hazardous material whereas ammonia is considered to be hazardous. Tests using urea injection have resulted in more than $65 \%$ NOx reduction with a very low ammonia slip of about 5 ppm (367).

The Occidental ammonia control system is an experimental bench scale technology that attempts to provide simultaneous control of PCDD/PCDF, $\mathrm{HCl}$ and $\mathrm{NOx}$ and $\mathrm{SO}_{2}$ to a lesser degree, all by use of $\mathrm{NH}_{3}$ (514). The theory that Occidental believes is the basis for their process, one of two theories proposed, is that ammonia can prevent the formation of PCDD/PCDF by competing with the hydrocarbon precursors present for the available chlorine. Because $\mathrm{NH}_{3}$ is much more reactive with chlorine than the hydrocarbons are, ammonia chloride is more likely to form than PCDD/PCDF. $\mathrm{HCl}$ and $\mathrm{SO}_{2}$ control can be achieved by the reaction of these acid gases with $\mathrm{NH}_{3}$ to form ammonium salts. The 
challence is to provide tha aptirnum temperatures for sall formation and to condense and capture belore a is discherpud se a denee whille haze out the stack. NOx rectuction is accomplished by combining an Therrmat DeNbx syatem or a SCR system with the Occidental tectnology.

This process hes certain edvantages over other bechniques. For example, any technology that uses a sorbent muat hendes and ulinetely disposes of the spent sorbent. Whth the Occidiental concept, formation of cioxin is provoniad in the fint place. There is no landifl requirement because spent sorbent is not

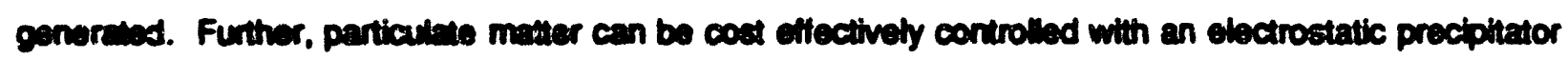
alons: a tabric filler with ofy serbent injection tor beg surtece comercion of dioxin, is not required.

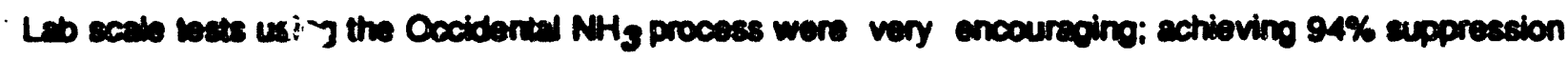
of PCDD, 100 percent suppression of PCDF, and $97 \%$ roctuction of HCl. Pilot scale lests are reporiedy proceeding at Occidentars Niagara Falls tacilly.

\section{A.26 Syrtem Yendore}

\section{A26.1 Eand Enctad Syatems}

Table A-8 lists, by vendor, all the U.S. fiald erected mass buin facimibs that were existing or in advanced plaming as of 1990 (387). Dominating this manket are Oojon 7rojocts, Inc. with 17 iacillies and Whoelabrator Technologies, Inc. with 14 facillies. The major vendors are described briatly following the tablo. 


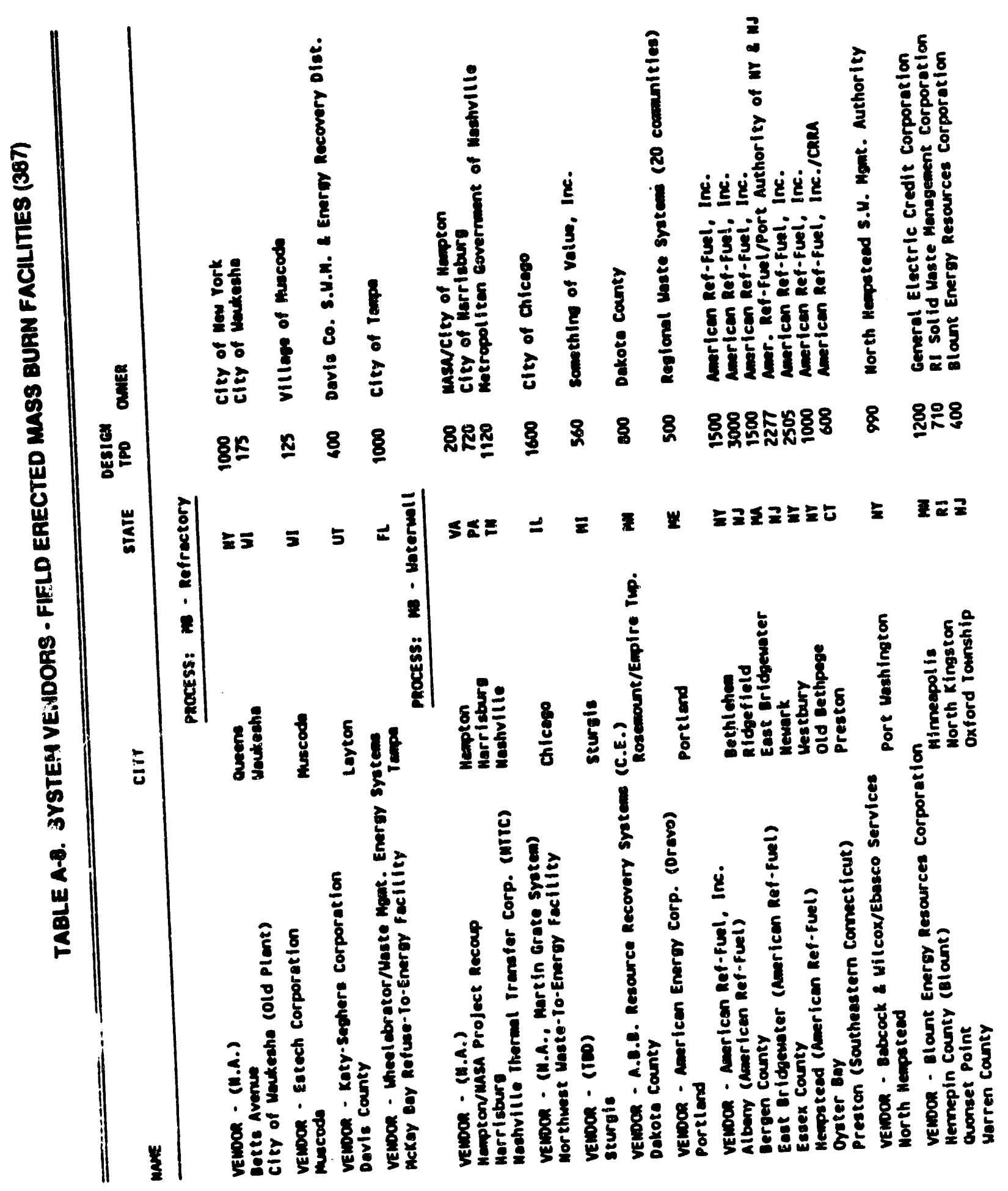




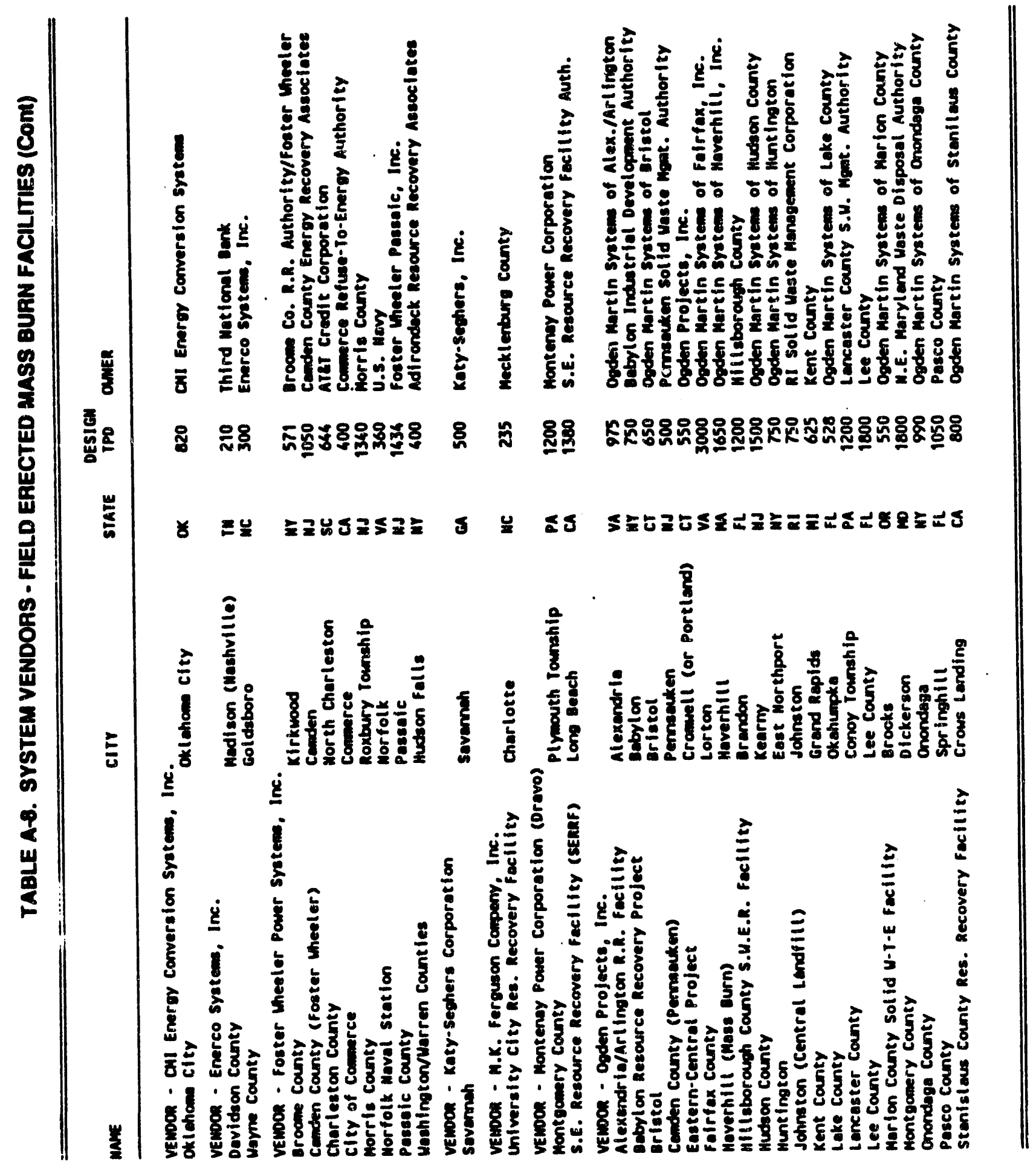




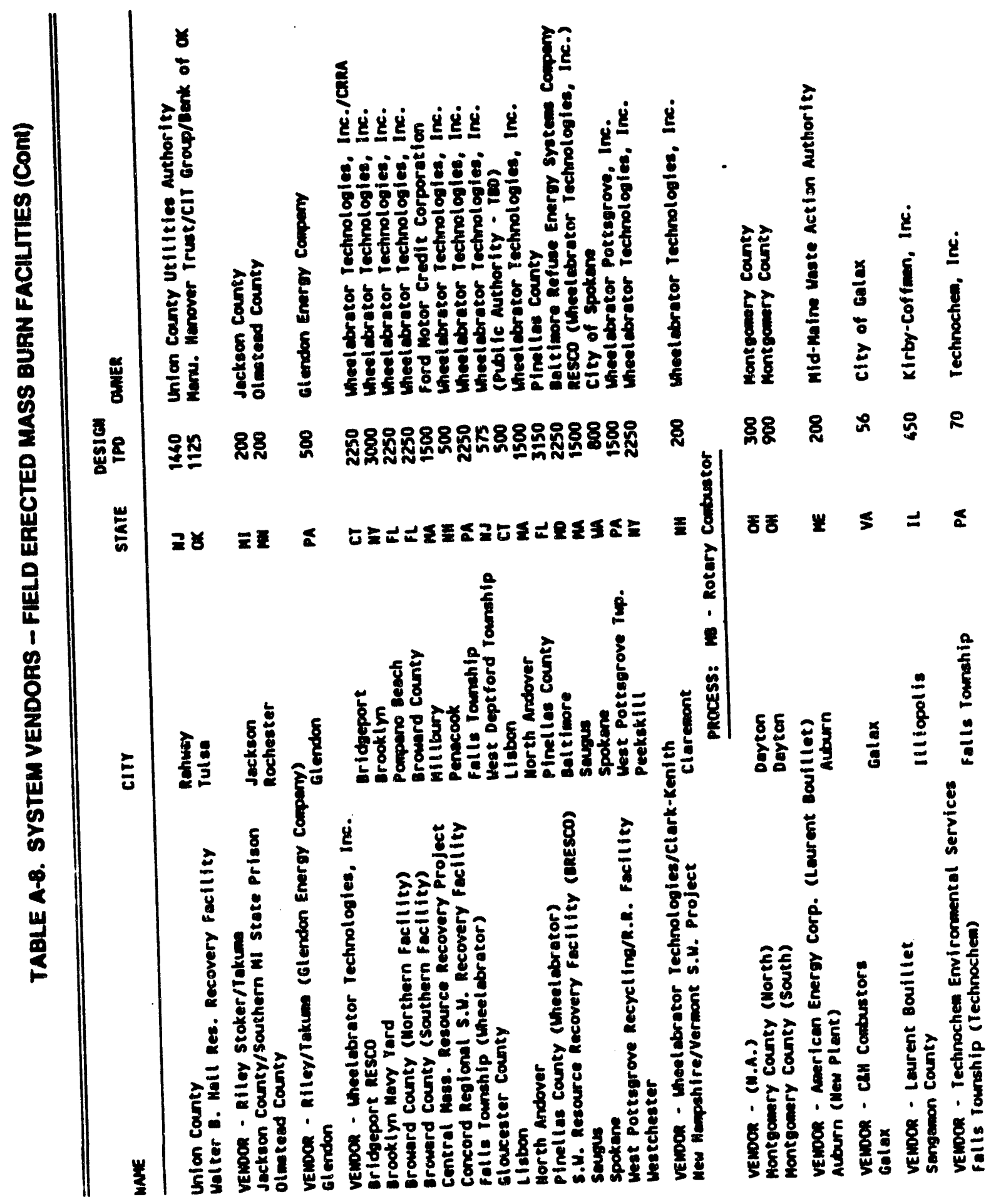




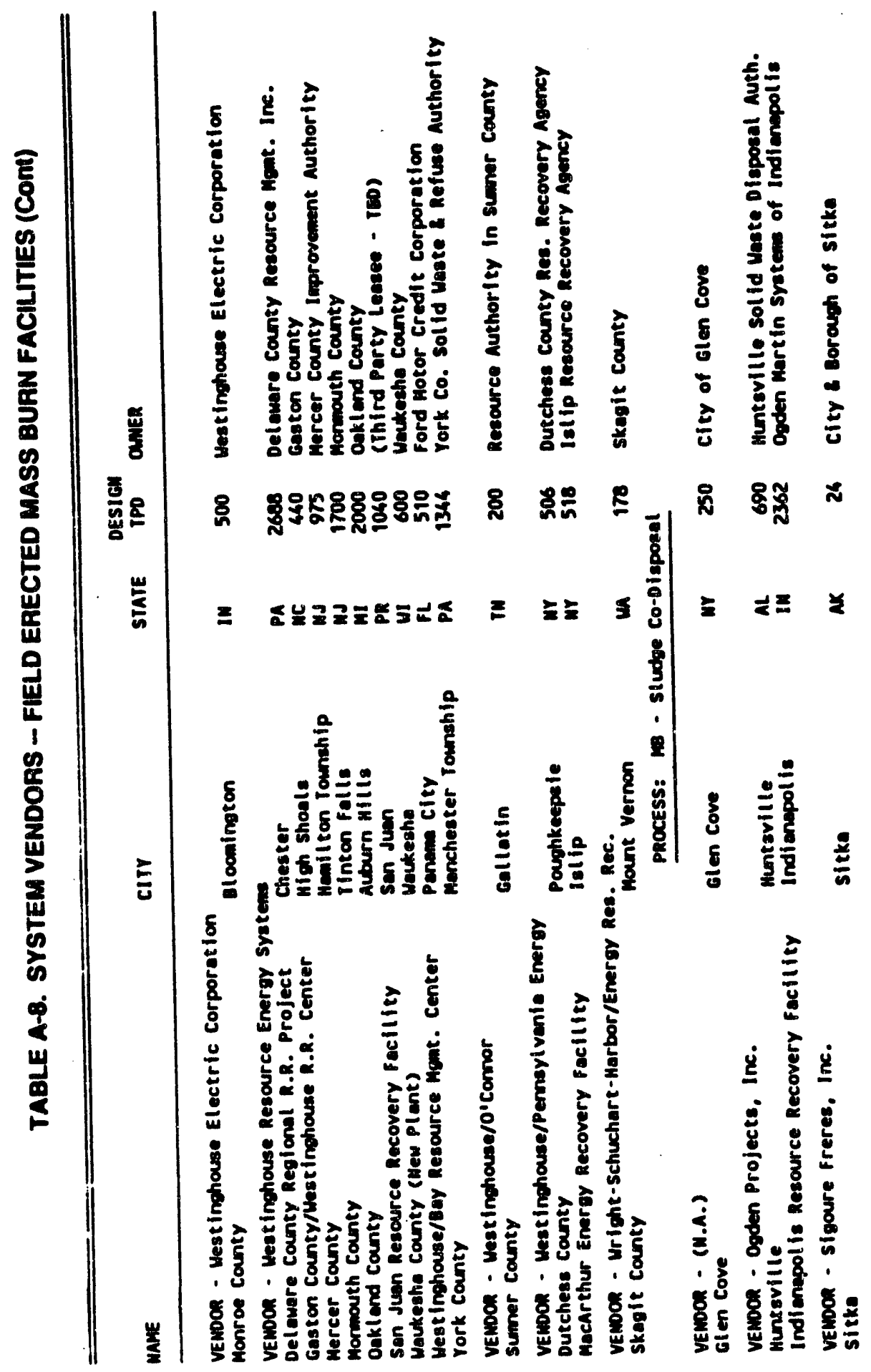


The American Eneray Compration has acquired the comestic rights to the Steinmuller technology from Dravo Energy Resources, Inc. This system utilizes a European style reciprocating grate, waterwall, excess air tectnology. Plants using this technology are usually larger than 550 TPD (472). As of 1990, three U.S. facimlies used the Stoinmuller technobogy, one of which (Portland, Mairis) is an American Energy Corporation facllyy (387). The American Energy Corporation also holds domestic rights to the French Laurent-Boulliet rotary kin technobgy (472). As of 1990, there were no Laurent-Boulllet faclilites in the U.S.

American Refi-Fued holds U.S. rights to the German Dusseldort roller grate technology. The Amorican Ref-Fuel technoboy is applied at a scale usually from 1,000 to 3,000 TPD. Two facilties were in shakedown and one in operation as of 1990; four were in advanced planning or construction stages.

Asea Bromn BoverikCombustion Enoineering has rights to the DeBartolomeis S.p.A. grate. As of 1990, Asea Brown BovervCombustion Engineering had one facility (Dakota County, Minnesota, 800 TPD) in advanced planning with none in construction or start-up (387).

Eoster-Wheeler_Power_Systems. Inc. does not have exclusive licensing rights to any mass bum technology and uses a Detrolt Stoker reciprocating grate, or a Dusseldorf grate (472). As of 1990, five Foster-Wheler facilities existed in the U.S. using the Detrolt Stoker system (387). All Foster-Wheoler tacilities use Foster-Whoeler boilers; American Ref-Fuel's Essex County, NW facillty also uses a Foster-Wheeler boiler. Foster-Wheeler's facilities range from the 360 TPD Norfolk, VA plant to the 1,050 TPD Canden County, NJ facility.

Katy-Sephers, a unit of Katy Industries, provides excess air systems as equipmemt only or as a full-service (472) and is one of the fow boiler vendors offering a refractory fumace. Katy Industries holds the U.S. license to the European Seghers Engineering reciprocating inclined grate. Support services are provided by Fulton Iron Works, a subsidiary of Katy Industries. There are two 550 TPD plants developed by Katy-Seghers operating in the U.S.: one in Savannah, Georgia and the other in Davis County, Utah (472, 387). Seghers Engineering has approximately 18 domestic waste processing plants operating in Europe (605). 
The Keeler Boiler Company and Keeler/Don-Oliver offer both a rotary kiln mass bum system and a reciprocating grate system $(235,472)$. Unit capacties range from 50 to 750 TPD, and moctularization of the units is an option in some applications. As of 1990, four U.S. facillties used the Keoler reciprocating grate boller system (orates are actually manutactured by Martin, Von Roll, or Detrolt Stoker) (387). The Delaware County, PA facility uses a Keeler boller with the Westinghouse/O'Connor rotary combustor.

The Montenay Pomer Comporation has the rights to the Morse-Boulger cascading grate, but Montenay also uses Von Roll, O'Connor, Martin, Steinmuller and Zum (472). Montenay is involved with the construction or operation of eight facillties in the U.S. and Canada (472). The only U.S. facilty originally developed by Montenay is the Key West, Florida facilly; all other Montenay plants involve ellher facility renovation and/or operation contracts (472). Montenay bok over two Dravo facilities, the Montcomery County, PA plant, and the S.E. Resource Recovery Facility (SERRF) plant in Long Beach, CA.

Qaden Martin owns the U.S. rights to the reverse-reciprocating Martin grate. The fuel foed chute and the ash discharger are also proprietary equipment (235). As of 1990, Ogden Martin had twelve plants on line, one in startup, and four in construction (387). Ogden Martin primarily constructs plants larger than 550 TPD (472).

Biley Eneroy Systems is a full service designerect company with domestic rights to the Japanese Takuma reciprocating grate (402). Riley systems are excess air systems with the Takuma step grate stoker. Riley provides a system called Automatic Combustion Control that stabilizes the steam flow at a predetermined rate by averaging the fuel fuctuations and maintains the desired steam flow by automatically varying the fuel input (235). In addition to regulating the steam flow, this system also controls the fumace conditions. As of 1990, Riley had constructed two facilities in the U.S. (387).

The Volund company is a Danish firm that offers the System Volund mass bum technology. The domestic branch, Volund USA, is jointly owned by The Volund Company and Waste Management. Volund USA holds the North American rights to the System Volund technology with the exception of a few geographic areas where Wheolabrator Environmental holds the license. The Volund technology consists of a stepped reciprocating grate similar to the Riley/Takuma system (472). Most of the lower furnace is lined with refractory. Volund offers the only two way gas system that completely mixes the flue gases. Volund had a rotary kiln type combustor, but no longer offers it for mass bum (472). As of 1990. Volund provided boiler systems for three U.S. facilities ranging from 235 to 2250 TPD (387). 
The Westinghouse Elegtic Copporation has obtained the rights to the O'Connor rotary kiln combustor. The O'Connor combustor combines the better features of rotary kilns without the disadvantages of a retractory liner and uses a watenwall boiler without a moving grate system (608). The train size for the O'Connor fectnolooy is usually 120 wo 170 TPD (472). As of 1990, Westinghouse had one facilty in construction and five in operation using the O'Connor rotary combustor (387). This technology has also boen applied in Japan and Thalland.

Whaelabrator Environmental Systems has the domestic rights to the European Von Poll grate technobgy (472). As of 1990, Wheolabrator had 14 existing facillties in the U.S. (387), 11 of which use the Von Roll grate system. Two of the remaining three facillies use Mantin grates, while the cther uses the Volund system. Babcock \& Wilcox (B\&W) waterwall bollers are used at eight of their fourtoen facilties, the remainder use Volund and Riley Stoker (two facilities each), and Von Roll and Keeler/Dorr-Oliver (one facilty each) (387). Wheelabrator acquired all of Waste Management's waste-to-energy assets in 1988. Waste Management had previously acquired selected rights to the System Volund technology, and Volund is licensed to manufacture the Eckrohr boiler. The Eckrohr boiler is the most commonly used natural circulation boller both in Europe and Japan for MSW combustion (235).

\section{A.2.6.2 Modular Systems}

Table A-9 lists, by system vendor, all the U.S. modular mass bum facilities that were in advanced planning or existing as of 1990 (387). The primary MWC modular boiler supplier is Abco, who supplies the waste heat boilers to Consumat and Synergy Clear Air (472), both modular system vendors. Consumat dominated the modular market in the early 1980s, but has won relatively fow projects in the second half of the decade (520). The system vendors are described briefly following the table. 


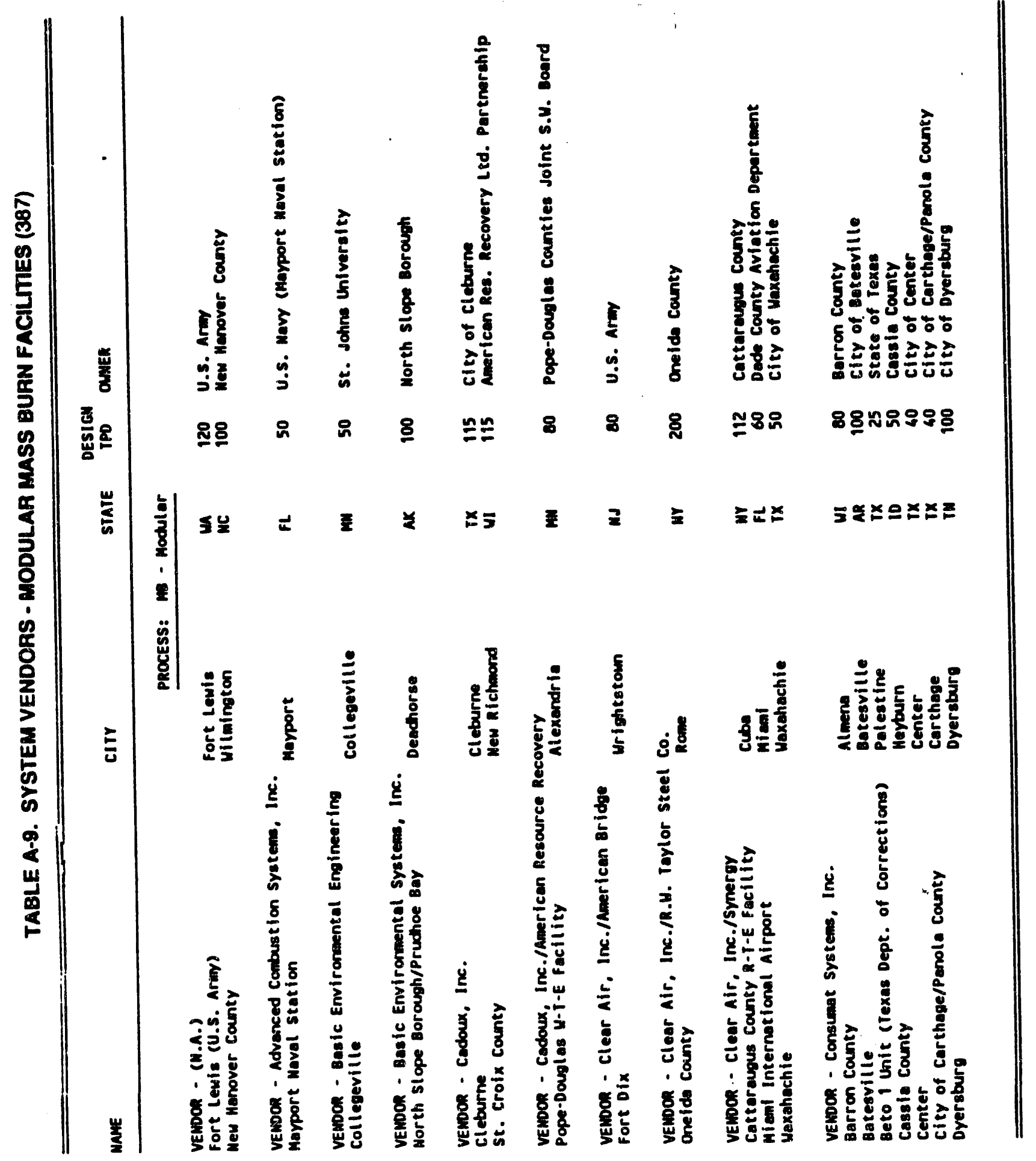




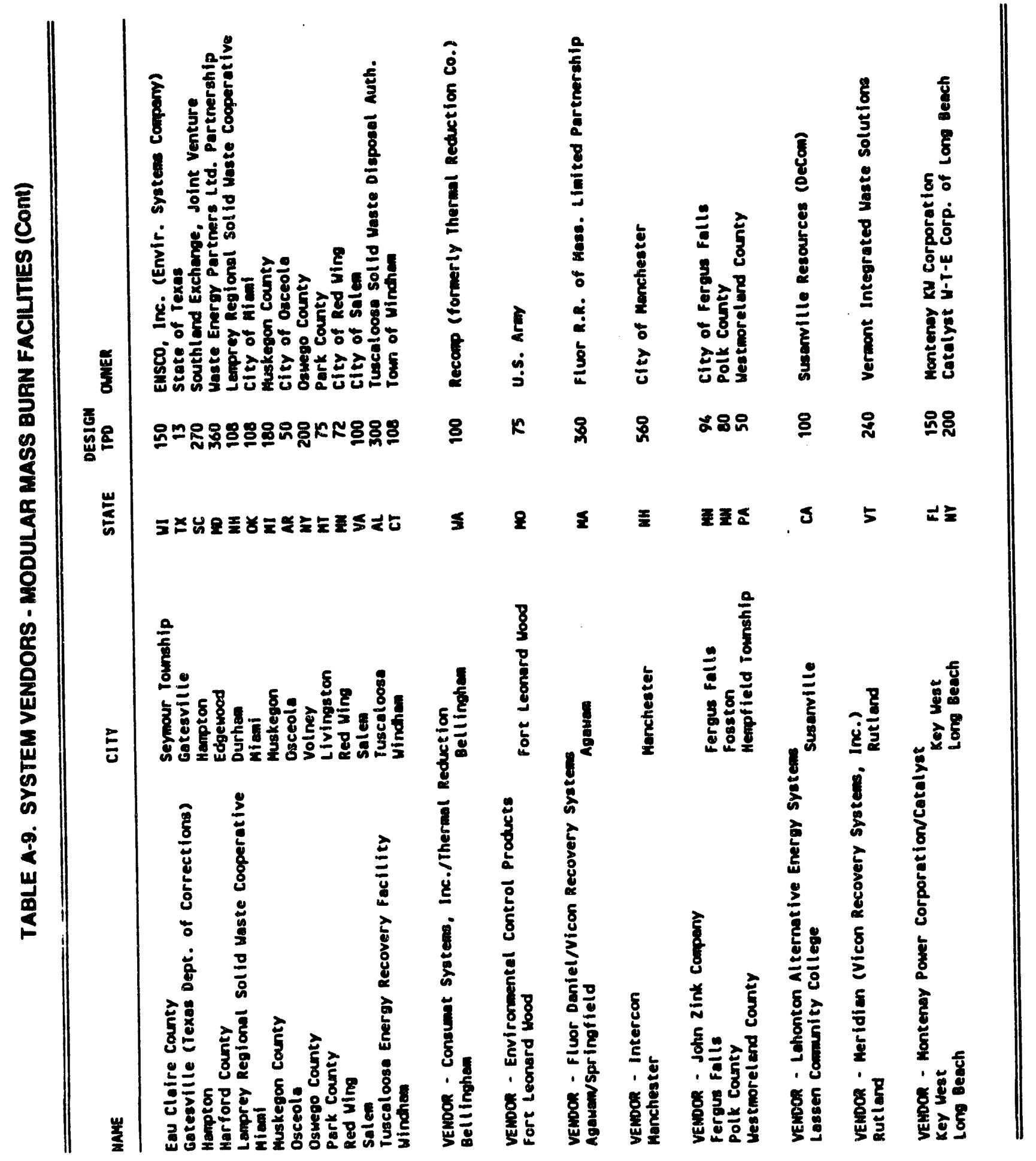




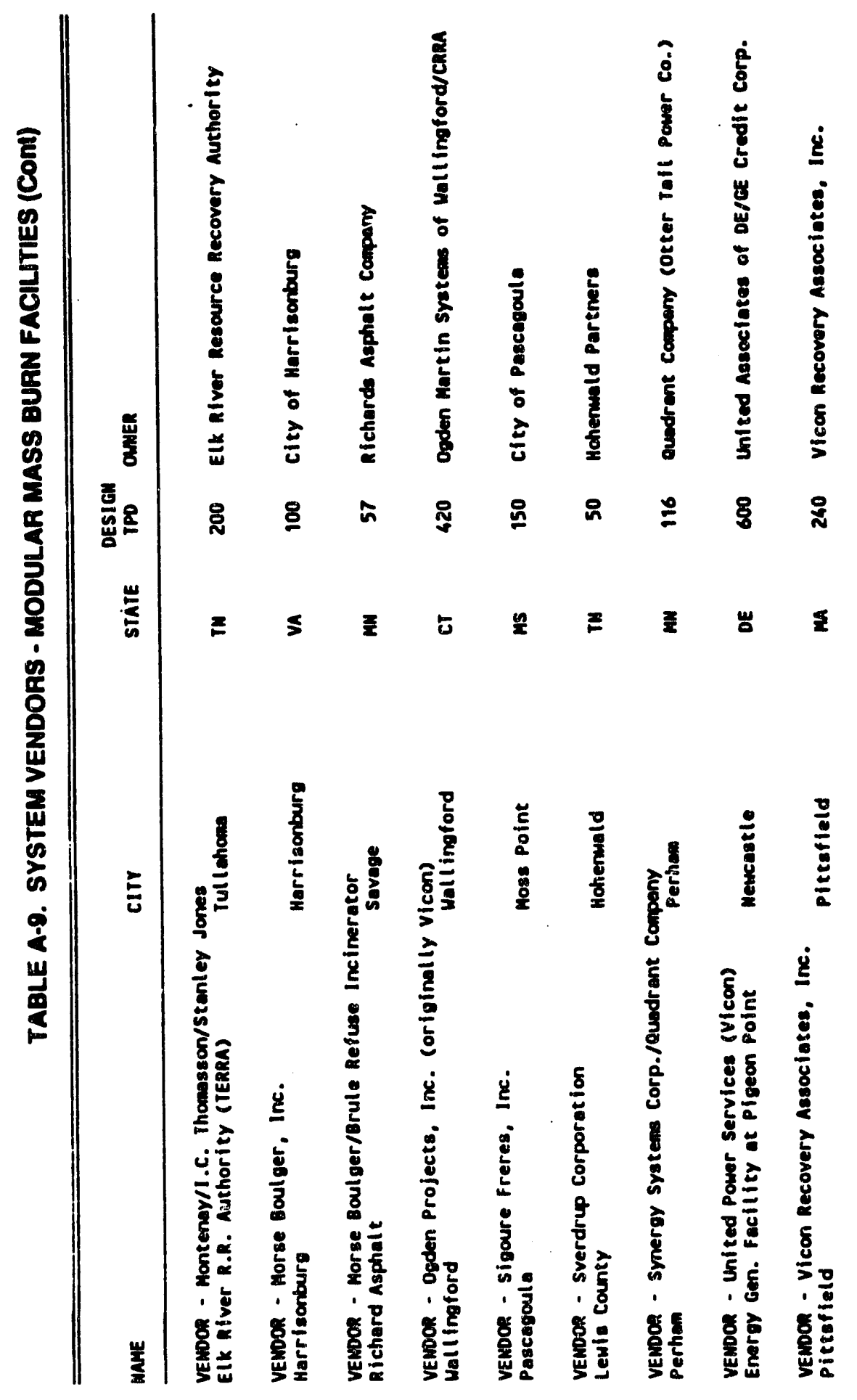


Basic Envimnmental Enoineering manufactures a multi-stage, watenwall boller unit (235). These units are mainly provided for dedicated facilties and hospital incineration systems, athough they have constructed two MSW facilites in the U.S. $(387,472)$. Individual units can be continuous or batch fed and range in sze from 4 million to 64 million Btuhr of input energy (235). Basic Environmental is the only controlled air vendor to offer a waterwall membrane in the primary chambor in addition to the normal waste heal boller downstream. Major modifications were made on Basic's two facilities, reportectly due to defective refractory material. Many of the system modifications developed for these two facilities are reported to have been incorporated into new designs (472).

Cadoux America. Inc, offers systems ranging in size from 25 to 200 TPD, in both starved and excess air versions (472). Cadoux uses the pll and crane feed method, and rams to move the material through the combustion chamber (606). Both the primary and secondary chambers are refractory brick and coating lined. As of 1990, Cadoux has three facilities in operation, all using multiples of their 38.4 TPD unit (472). One of these facilities, located in Cleburne, Texas, combusts medical wastes.

Clear_Air. Inc. uses the controlled air technology and is batch fed, with a reciprocating grate in the primary chamber (472). Auxiliary fuel bumers are used to supplement the primary tuel it its caloritic value is too low (612). Material is fed into the primary chamber by a ram feeder and is moved through the chamber by a reciprocating grate. As of 1990, Clear Air had five operating plants in the U.S. (387).

Consumat Systems, Inc is the largest supplier of modular MSW systems $(235,472)$. Reportedly, over 70 systems are under construction or operating to produce energy from misesilaneous wastes (611); although GAA reports only 20 U.S. MSW facilities (387). The total number of worldwide installations including energy and non-energy systems exceeds 4,500 with facilities in all 50 states and 34 foreign countries (611). The size of their plants usually is in the range of 40 to 100 TPD, although the largest Consumat system is 360 TPD.

Consumat utilizes the starved air, sub-stoichiometric primary chamber approact; (472). The tipping floorwheel bader method of storage and feed is used, with a ram feeder introducing the material into the primary combustion chamber. Transter rams move the material through the chamber. A wet ash removal system is utilized. 
Ecolaire markets the Bunn \& Sorenson technology. Brunn \& Sorenson is a small Danish company that procuces high temperature hot water (HTHW) systems (277). One plant has been buit in Susanville, CA, though $I$ is reported as being unsuccessful (574). Government Advisory Associates reports that this facilly is temporarily shut down for modifications (387).

Synerov Syouns manutactures a modular mass bum reciprocating grate. They provided this system on two Clear Air projects (Miami, Florida and Waxahachie, Texas) and on one facility developed independently. Reportedly, the company has been sold (472).

Technizus Emvinonment Sicoure is a French company formarly known as Sigoure-Freres. Sigoure-Freres constructed two U.S. faciltios in Sitka, Alaska and Pascagoula, Mississippi (387). Each of these uses a different modular design. The Sitka facilty co-disposes studge in a York Shipley boiler. The Pascagoula facility uses a primary fumace that rotates about a vertical axis. The waste is agitated by two sets of pokers which lith and tum it to expose all sides to the combustion conditions. Ash is plowed off by a stationary plow (472).

Iechnochem Emvironmental Systems, Inc is the U.S. company of Technitalia S.p.A. This firm offers a modular fechnology with a continuous cast refractory lined rotary kiln, and two combustion chambers. The rotary kiln drum has intermal flighting to lift and advance the MSW (472). As of 1990. Technochem has provided equipment for only one facility - Skagit County, Washington (387). A second facility using Technochem equipment is reportedly planned for Williams Township, PA $(387,472)$.

\section{A.3 ECONOWIC DATA}

Economics are a major determinant in the decision to construct and operate a waste-to-energy system. As indicated earlier, the source of much of the cost data used in this appendix for mass bum facilities is the Government Advisory Associates 1991 Resource Recovery Yearbook (387). Summary cost tables are presented later in this section and the corresponding detailed tables derived from that database are included as attachments to this document.

Models based on the design and cost of municipal waste combustors often provide valuable insight into the key factors that drive capital, OsM and annualized costs, in general. 
A model for the estimation of plant capital costs (at the plus or minus $25 \%$ level for 1990) has been developed on the basis of 61 randomly selected waste-to-energy facilities ranging in size from 150 to 3500 TPD (20). Mulliple linear regression analysis was pertormed on vendor quoted costs exclusive of land acquisition, intrastructure improvements and owner administration expenses, which can drive the costs up by as much as $50 \%$ (472).

Key parameters upon which the model is based include: plant capacity, number of combustion units, type of facilly constructed (moctular or field-erected), year the plart was priced, bcation of plant, type of air pollution control equipment, procurement method, power block construction, combustion chamber (refractory or water wall), energy product and any unique features.

The aborithm doveloped by Rigo and Conley (20) for predicting 1990 capital costs is presented below. The multiple regression coefficient is 0.914 and the coefficients derived are statistically sionificant (472).

$$
\begin{aligned}
\$ 1000 / T P D= & 112.6-.0129(T P D)+7.41(F A B 1)-10.4(F A B 2)- \\
& 26.1(\text { FTYPE })-23.4(\text { ETYPE })
\end{aligned}
$$

where: TPD = nameplate,

FAB1 = 1 for modular, 0 for other,

FAB2 - 1 for extensive use of modular techniques,

FTYPE = 1 for refractory wall,

ETYPE $=1$ tor heating steam only.

Several earlier modeling efforts have boen reported by Rood (471). Of those, an earlier algorithm by Conley and Rigo is presented here to fu ther illustrate the capital cost functionality according to the parameters mentioned above. The original squation as reported (471) has been adjusted for escalation using the CE plant equipment cost index from 1988 to 1990.

$$
\begin{aligned}
\$ 1,000 / T P D= & (1.044)[92.92-.0227(T P D)+51.37(\text { FACTOR1 })-41.21(\text { FACTOR2) }+ \\
& 8.47(\text { FACTOR3) }-8.17(\text { FACTOR4) }-5.63) \text { FACTOR5) }]
\end{aligned}
$$

where: FACTOR1 $=1$ if TPD $>2000,0$ if TPD $<2000$, (MSW combusted),

FACTOR2 = 1 if modular, 0 H other (mass bum or RDF)

FACTOR3 = 1 if spray iryerfabric filler, 0 it other (electrostatic precipitator),

FACTOR4 = 1 if steam, 0 if producing electricai power or cogenerating both steam for process use and electrical power,

FACTOR5 = 1 if using ArchitecturaVEngineering firm for procurement, 0 if a full-service or turnkey approach is used. 


\section{Aas Enidfratedum}

\section{A3.1.1 contam}

Detallod caplal cost data for all exieting and advanced planned fibld enscted mass bum facillies (es of 19e9) are provided in Aftechments 3 and 4 to this document. Original ceppltal costs are given along with costs in 1990 dollars. Factities are listed by al pollution control mothools (Attachment 3) and by type of energy produced (Attachmonk 4). There is a significant range in the capital costs expressed on a collars/TPD basis which can be attributed to differences in the componerts of the capltal cost, the type of air pollution control equipment inctuded, the type of energy produced, and the year the facility was constnucted. Tables A-10 and A-11 summarize the data provided in the attachments with respect to dollarenon.

The 1989 Monmouth County, NW Resource Recovery Facilty Plan (411) describes a plant with 1,700 TPD capacily, 40 MWe power output, an air-cooled condenser, dry scrubberfiabric fitter air pollution control equipment, three frontend processing lines to recover recyclatiles, and three combustion lines. The from-end processing system is a key element in the faclity desion that integrates the mass bum and recycling tectnologies. It is planned to recover aluminum, ferrous metals, comugated cardboard, batteries, PET, HDPE, and film plastic. Appendix E (Material Recoverymaterial Recycling Technologies) provides a detailed discussion on this facilly. The capital costs, as estimated in the plan (Table A-12), include 520 million for the frontend separation system. For a throughput of 1,700 TPD, this project has a capital cost of \$135,294 per TPD inctuding the frontend system, or \$123,529 without the frontend system. The availability is expected to be 85 percent for the combustion plant. The facility is planned to have 156 employees including 75 hand pickers. 
TABLE A-10. SUMMARY OF CAPTAL COST BY APC TYPE W 1900 STPD FOR FIELD ERECTED MASS BURN FACUTES (B8T)

\begin{tabular}{|c|c|c|c|c|c|}
\hline & $\begin{array}{l}\text { No. OF } \\
\text { FACILITIES }\end{array}$ & LOW & HIGH & AVG & $\begin{array}{l}\text { STANDARD } \\
\text { DEVMTION }\end{array}$ \\
\hline \multicolumn{6}{|l|}{ Rotractory } \\
\hline ESP & 4 & $\$ 21,595$ & $\$ 104,234$ & $\$ 58,666$ & $\$ 35,033$ \\
\hline Dry Scrubber & 1 & $\$ 70,338$ & $\$ 70,338$ & $\$ 70,338$ & $\$ 0$ \\
\hline \multicolumn{6}{|l|}{ Watenvall } \\
\hline ESP & 23 & $\$ 29,930$ & $\$ 159,858$ & $\$ 85,922$ & $\$ 33,997$ \\
\hline Dry Scrubber & 50 & $\$ 45,488$ & $\$ 204,667$ & $\$ 115,621$ & $\$ 31,966$ \\
\hline Baghouse/FF & 1 & $\$ 128,989$ & $\$ 128,989$ & $\$ 128,989$ & 50 \\
\hline To Be Determined & 1 & $\$ 90,000$ & $\$ 90,000$ & $\$ 90,000$ & $\$ 0$ \\
\hline \multicolumn{6}{|l|}{ Rotary Combustor } \\
\hline ESP & 4 & $\$ 23,424$ & $\$ 85,628$ & $\$ 63,398$ & $\$ 24,552$ \\
\hline Baghouse/FF & 1 & $\$ 41,825$ & $\$ 41,825$ & $\$ 41,825$ & $\$ 0$ \\
\hline Dry Scrubber & 15 & $\$ 70,730$ & $\$ 200,000$ & $\$ 108,741$ & $\$ 34,942$ \\
\hline \multicolumn{6}{|l|}{ MSW/Sudge Co-fired } \\
\hline ESP & 2 & $\$ 175,626$ & $\$ 198,784$ & $\$ 187,205$ & $\$ 11,579$ \\
\hline Dry Scrubber & 2 & $\$ 40,136$ & $\$ 105,072$ & $\$ 72,604$ & $\$ 32,468$ \\
\hline
\end{tabular}


TABLE A-11. SUMMAAY OF CAPTAL COST BY ENERGY TYPE IN 1990 \$ $/ T P$ FOR FIELD ERECTED MASS BURN FACLITES (B87)

\begin{tabular}{|c|c|c|c|c|c|}
\hline & $\begin{array}{l}\text { NO: OF } \\
\text { FACILITIES }\end{array}$ & LOW & HIGH & AVG & $\begin{array}{l}\text { STANDARD } \\
\text { DEVIATION }\end{array}$ \\
\hline \multicolumn{6}{|l|}{ Refractory } \\
\hline Stoam & 3 & $\$ 21,595$ & $\$ 104,234$ & $\$ 51,193$ & $\$ 37,590$ \\
\hline Eloctricily & 1 & $\$ 81,084$ & $\$ 81,084$ & $\$ 81,084$ & $\$ 0$ \\
\hline Stoam \& Elec. & 1 & $\$ 70,388$ & $\$ 70,388$ & $\$ 70,388$ & $\$ 0$ \\
\hline \multicolumn{6}{|l|}{ Watenwall } \\
\hline Steam & 4 & $\$ 36,098$ & $\$ 142,000$ & $\$ 85,072$ & $\$ 37,713$ \\
\hline Eloctricily & 58 & $\$ 45,488$ & $\$ 204,667$ & $\$ 110,691$ & $\$ 32,515$ \\
\hline Steam \& Elec. & 13 & $\$ 32,930$ & $\$ 159,858$ & $\$ 93,149$ & $\$ 39,364$ \\
\hline \multicolumn{6}{|c|}{ Rotary Combustor } \\
\hline Steam & 1 & $\$ 41,825$ & $\$ 41,825$ & $\$ 41,825$ & $\$ 0$ \\
\hline Eloctricity & 13 & $\$ 23,424$ & $\$ 132,500$ & $\$ 91,728$ & $\$ 27,471$ \\
\hline Stoam \& Elec. & 6 & $\$ 63,277$ & $\$ 200,000$ & $\$ 115,374$ & $\$ 50,187$ \\
\hline \multicolumn{6}{|c|}{ MSW/Sudge Co-fired } \\
\hline Steam & 3 & $\$ 40,136$ & $\$ 198,784$ & $\$ 114,664$ & $\$ 65,122$ \\
\hline Steam \& Elec. & 1 & $\$ 175,626$ & $\$ 175,626$ & $\$ 175,626$ & $\$ 0$ \\
\hline
\end{tabular}


TABLE A-12. ESTIMATED CAPTIAL COSTS FOR THE MONMOUTH COUNTY RESOURCE RECOVERY FACIUTY (A41)

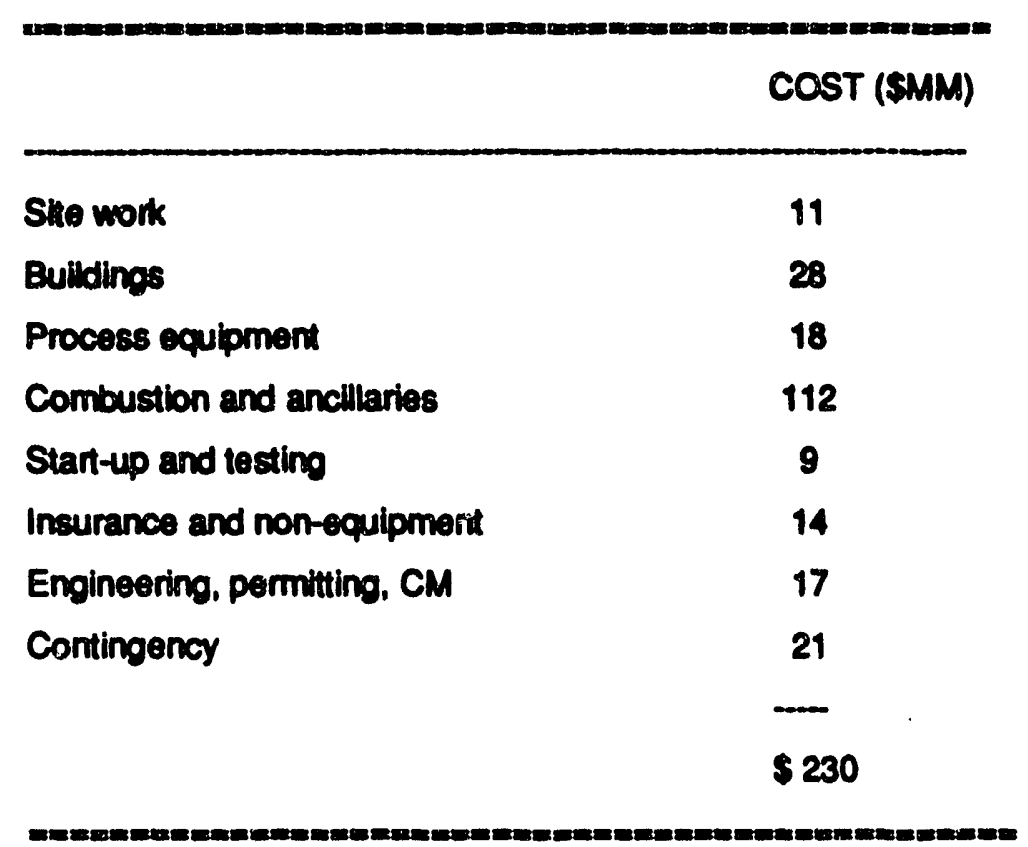

\section{A.3.1.2 Operratlon and Malntenance Costs}

Attachment 5 shows the operation and maintenance costs for all existing and planned field erected mass burn facilities as of 1990 (387). These data are summarized in Table A-13.

TABLE A-13. AVERAGE O\&M COSTS FOR FIELDERECTED MASS BURN FACILITIES (387)

\begin{tabular}{|c|c|c|c|c|c|}
\hline & $\begin{array}{l}\text { AVG. } \\
\text { SIZE, } \\
\text { TPD }\end{array}$ & $\begin{array}{l}\text { STON } \\
\text { WITH } \\
\text { DEBT } \\
\text { SERVICE }\end{array}$ & $\begin{array}{l}\text { STTON } \\
\text { WITHOUT } \\
\text { DEBT } \\
\text { SERVICE }\end{array}$ & $\begin{array}{l}\text { SNEAR } \\
\text { WITH } \\
\text { DEBY } \\
\text { SERVICE }\end{array}$ & $\begin{array}{l}\text { SYEAR } \\
\text { WITHOUT } \\
\text { DEBT } \\
\text { SERVICE }\end{array}$ \\
\hline Refractory & 540 & $\$ 67$ & $\$ 27$ & $\$ 7,606,250$ & $\$ 3,395,000$ \\
\hline Watenwall & 1138 & 362 & $\$ 25$ & $\$ 20,008,478$ & $\$ 8,007,144$ \\
\hline Rotary & 759 & $\$ 50$ & $\$ 19$ & $\$ 10,222,591$ & $\$ 4,721,405$ \\
\hline MSW/Shdge & 832 & 544 & $\$ 33$ & $\$ 12,196,667$ & $\$ 4,080,000$ \\
\hline
\end{tabular}


The estimated OeM costs for the proposed Monmouth County, NW facilly are presented in Table A-14.

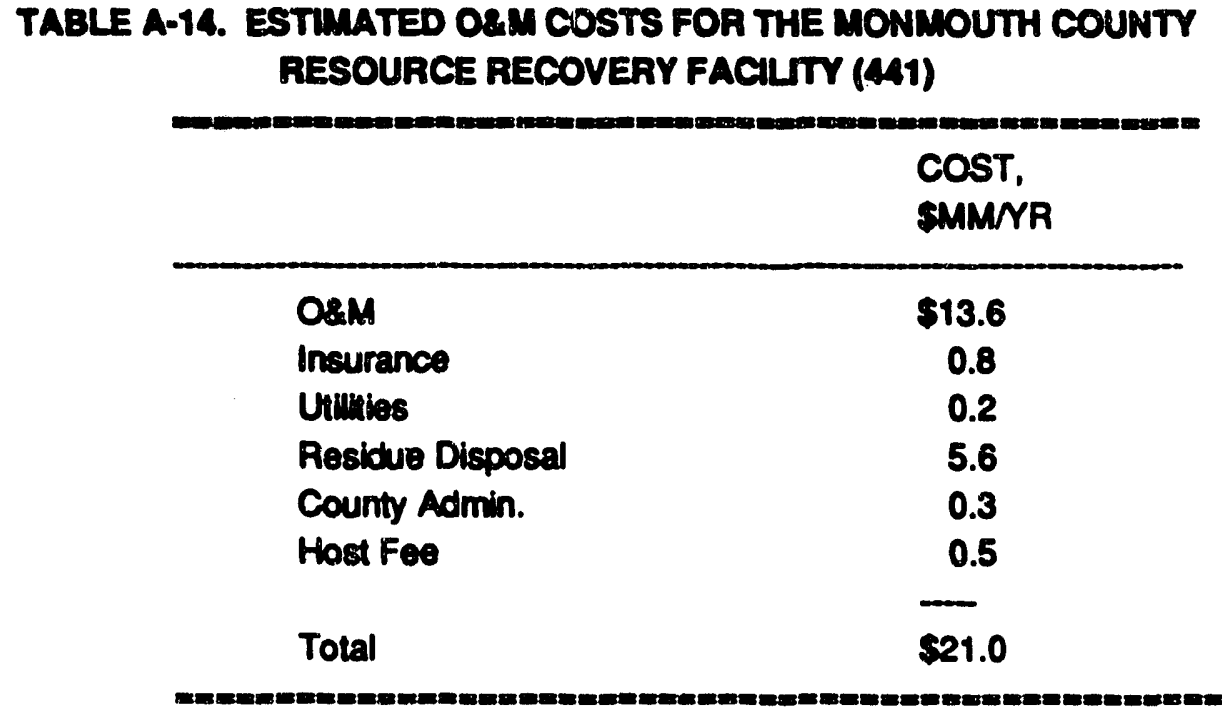

Of this \$21 million annual total, $\$ 10$ million is for the front-end process. On a unit cost basis, this is $\$ 34$ per ton including the front-end process, or $\$ 18$ per ton excluding the from -end process.

Attachment: details the full-time staff for field erected mass bum facilities, including management and non-mansgement employees. Also, the total number of full time employees is normalized on a per 100 TPD basis. These data are summarized in Table A-15.

TABLE A-15. SUMMARY STAFFING DATA FOR

FIELDERECTED MASS BURN FACILITES (387)

\begin{tabular}{|c|c|c|c|}
\hline & $\begin{array}{l}\text { NUMBER OF } \\
\text { FACILITIES }\end{array}$ & $\begin{array}{l}\text { FULL TIME } \\
\text { EMPLOYEES } \\
\text { PER } 100 \text { TPD }\end{array}$ & $\begin{array}{l}\text { STANDARD } \\
\text { DEVIATION }\end{array}$ \\
\hline Pefractory & 5 & 7.8 & 2.0 \\
\hline Waterwall & 74 & 5.7 & 3.4 \\
\hline Rotary Combustor & 20 & 10.4 & 9.7 \\
\hline MSW/Sudge & 4 & 10.7 & 7.2 \\
\hline
\end{tabular}




\section{A.32 Modularsyrtems}

\section{A.32.1 Conplinteonte}

Cost data on all existing and planned modular systems as of 1990 (387) are detalled in Aftachments 7 and 8 according to air pollution control equipment utilized and type of energy produced, respectively. The overall capital cost for modular systems in 1990 dollars ranges considerably, from $\$ 16,742$ to $\$ 159,437$ per TPD. This lange range may be attributed to differences in the components of the captal cost, the type of air pollution control equipment included, the type of energy produced, and the year the facilty was constructed. Tables A-16 and A-17 summarize this data. Of the 60 plants listed in the attachments, 22 had undergone modifications, the cost of which ranged from $\$ 100,000$ to $\$ 25,000,000$. Modifications included upgrading of air pollution control systems, boller repair, and installation of additional units.

TABLE A-16. SUMMARY OF MODULAR FACILITY

CAPITAL COST IN 1990 \$TTPD BY APC TYPE (387)

\begin{tabular}{|c|c|c|c|c|}
\hline & LOW & HIGH & AVG & $\begin{array}{l}\text { STANDARD } \\
\text { DEVIATION }\end{array}$ \\
\hline Electrostatic Precip & $\$ 35,970$ & $\$ 159,437$ & $\$ 81,351$ & $\$ 35,512$ \\
\hline Dry Scrubber & $\$ 22,473$ & $\$ 101,497$ & $\$ 74,419$ & $\$ 22,675$ \\
\hline Baghouse/Fabric Filter & $\$ 33,484$ & $\$ 90,620$ & $\$ 62,052$ & $\$ 28,568$ \\
\hline Two Chamber Fumace & $\$ 16,742$ & $\$ 81,139$ & $\$ 48,458$ & $\$ 17,593$ \\
\hline Cyclones & $\$ 31,972$ & $\$ 68,482$ & $\$ 47,695$ & $\$ 15,329$ \\
\hline Wet Scrubber & $\$ 45,917$ & $\$ 45,917$ & $\$ 45,917$ & 50 \\
\hline
\end{tabular}


TABLE A-17. SUMMARY OF MODULAR FACILTY

CAPITAL COST W 1990 STPD BY ENERGY TYPE (387)

\begin{tabular}{lllll} 
& LOW & HIGH & AVG & $\begin{array}{c}\text { STANDARD } \\
\text { DEVIATION }\end{array}$ \\
\hline Steam & $\$ 16,742$ & $\$ 93,144$ & $\$ 56,884$ & $\$ 20,384$ \\
Electricity & $\$ 22,473$ & $\$ 147,665$ & $\$ 88,507$ & $\$ 37,688$ \\
Steam \& Eloctrictly & $\$ 44,241$ & $\$ 159,437$ & $\$ 88,922$ & $\$ 30,602$ \\
Hot Water & $\$ 83,709$ & $\$ 83,709$ & $\$ 83,709$ & $\$ 0$
\end{tabular}

\section{A.3.2.2 Operatlon and Maintenance Costs}

Attachment 9 provides the operation and maintenance costs for all planned and existing modular mass bum facilties as of 1990 (387). The average O\&M cost per ton for modular system is shown to be \$57non inchuding debt service, and \$43hon without debt service costs. Aftachment 10 shows the statting levels for all existing and planned modular mass bum facilities as of 1990 (387). Both management and non-managemem employees are included. Normalized on a per 100 TPD basis, the average full time staff totals 16.8, including both management and non-management employees.

\section{A.3.3 Alr Pollution ControLEquipment Costs}

The capital and O\&M costs of various systems for controlling MWC emissions are presented in Tables A-18 through A-23. These costs were estimated using the model plant approach (298). Original costs were August 1986 prices; they have been escalated to 1990 costs using the Chemical Engineering Plant Cost Indices. The capital cost estimates are based on 25 percemt excess combustor capacity plus a 20 percent contingency. The cost of the control system and any auxiliary system such as ductwork, I.D. fan, etc are included. Spray dryer systems do not require a special acid resistant lining and consequently, a credit has been applied to the cost of spray dryer systems to account for this cost savings. Separate costs are provided for modular and field erected facilities, and a separate tabulation is provided for now and existing model facilities. 


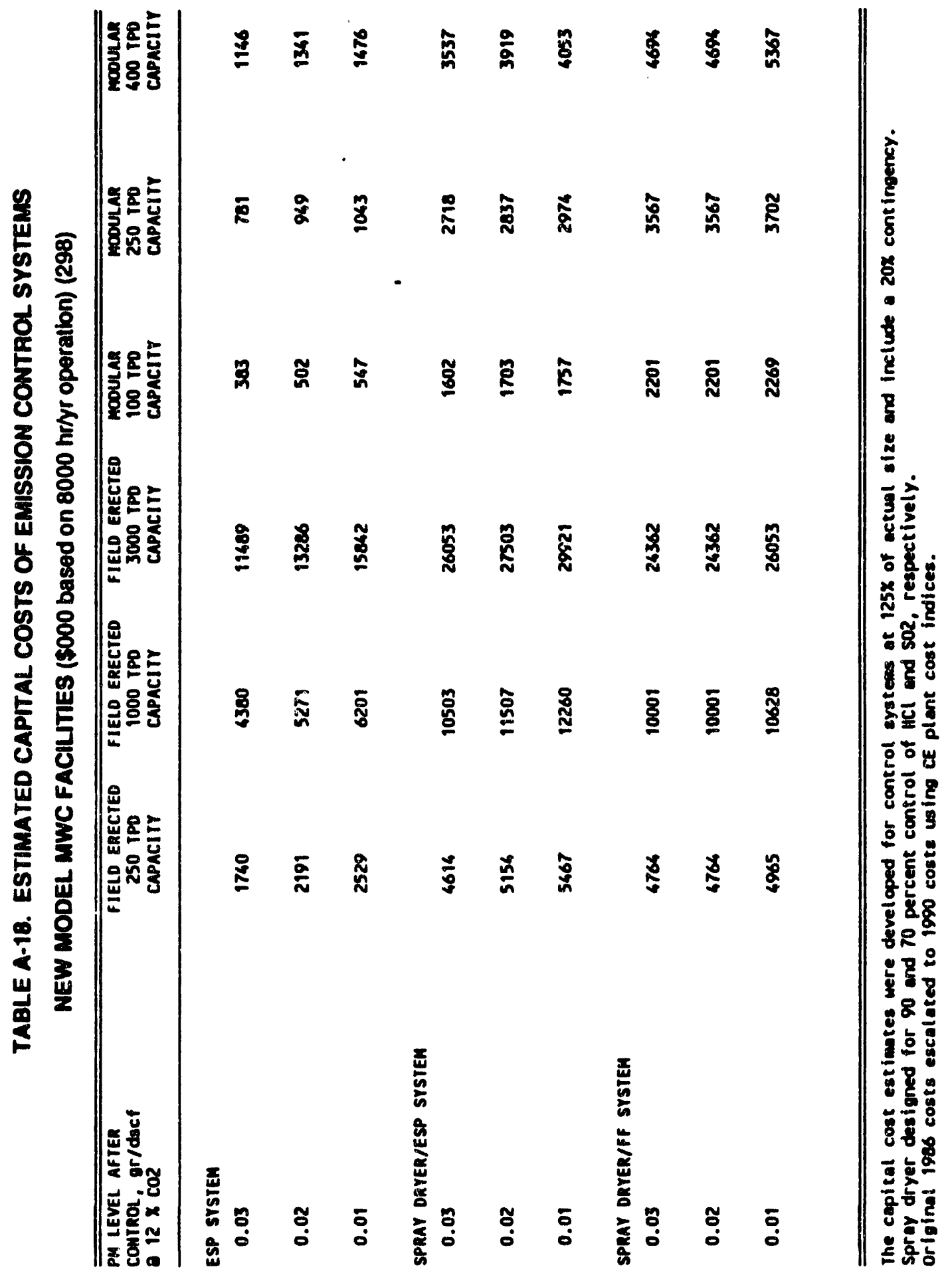




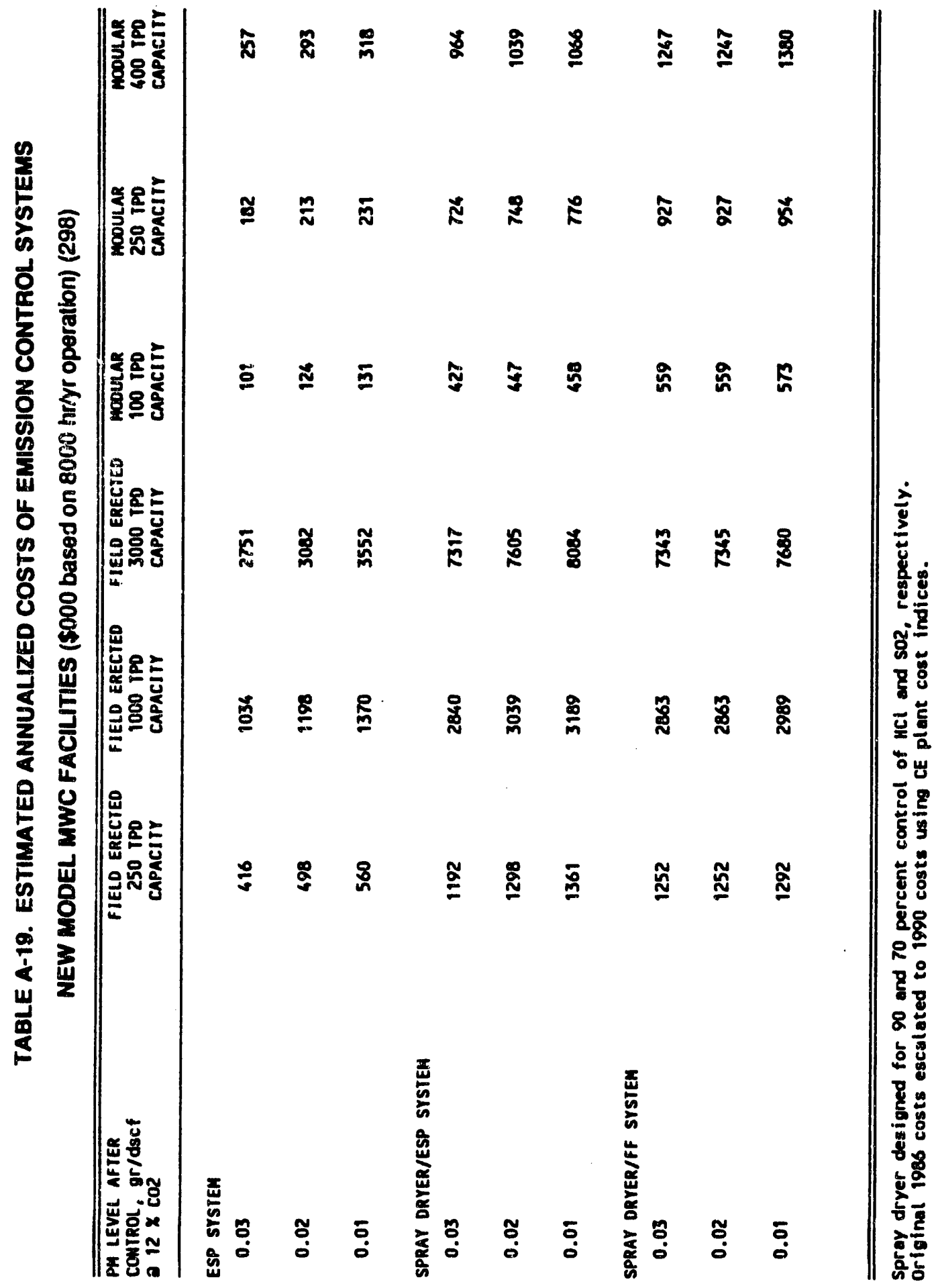



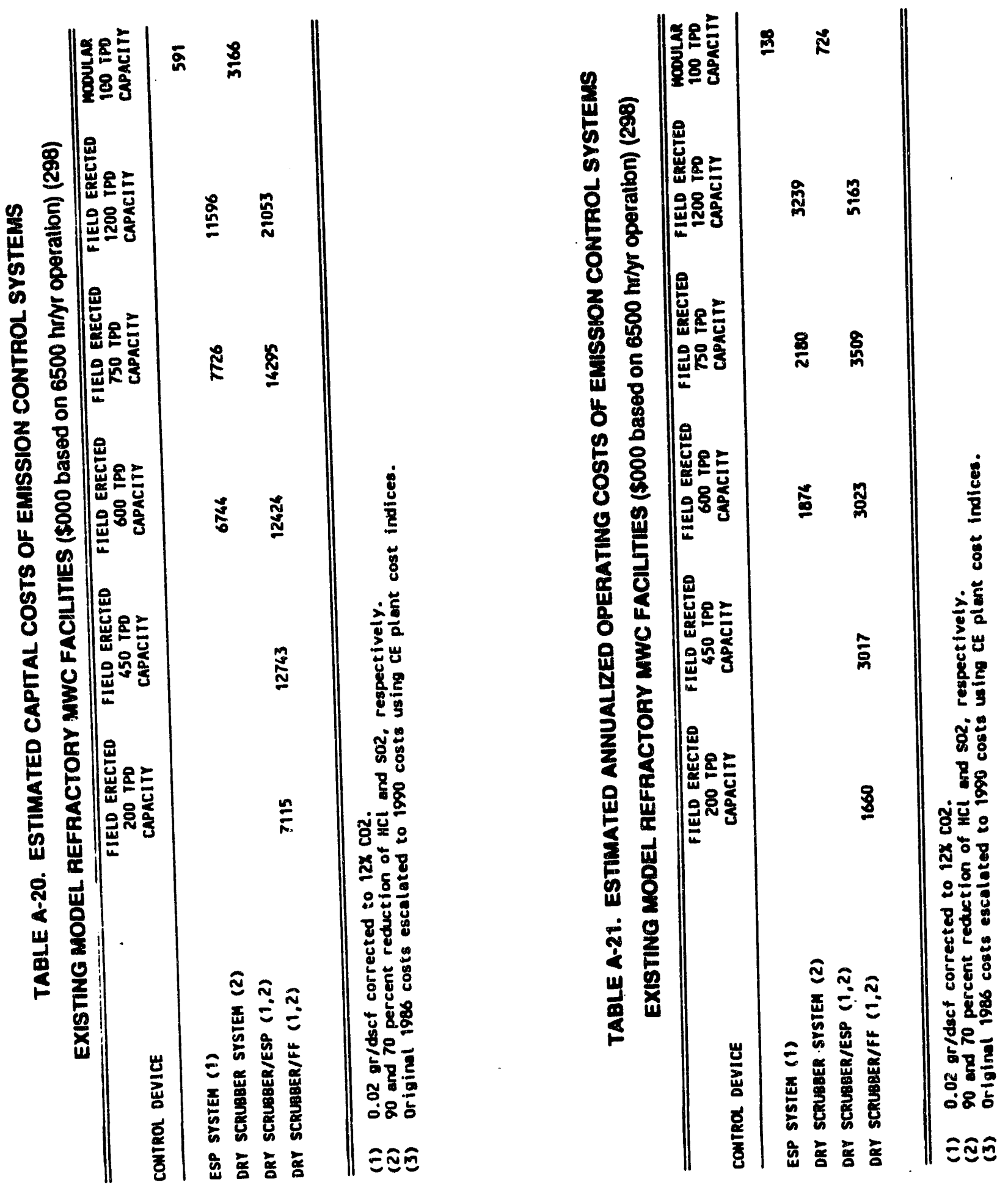

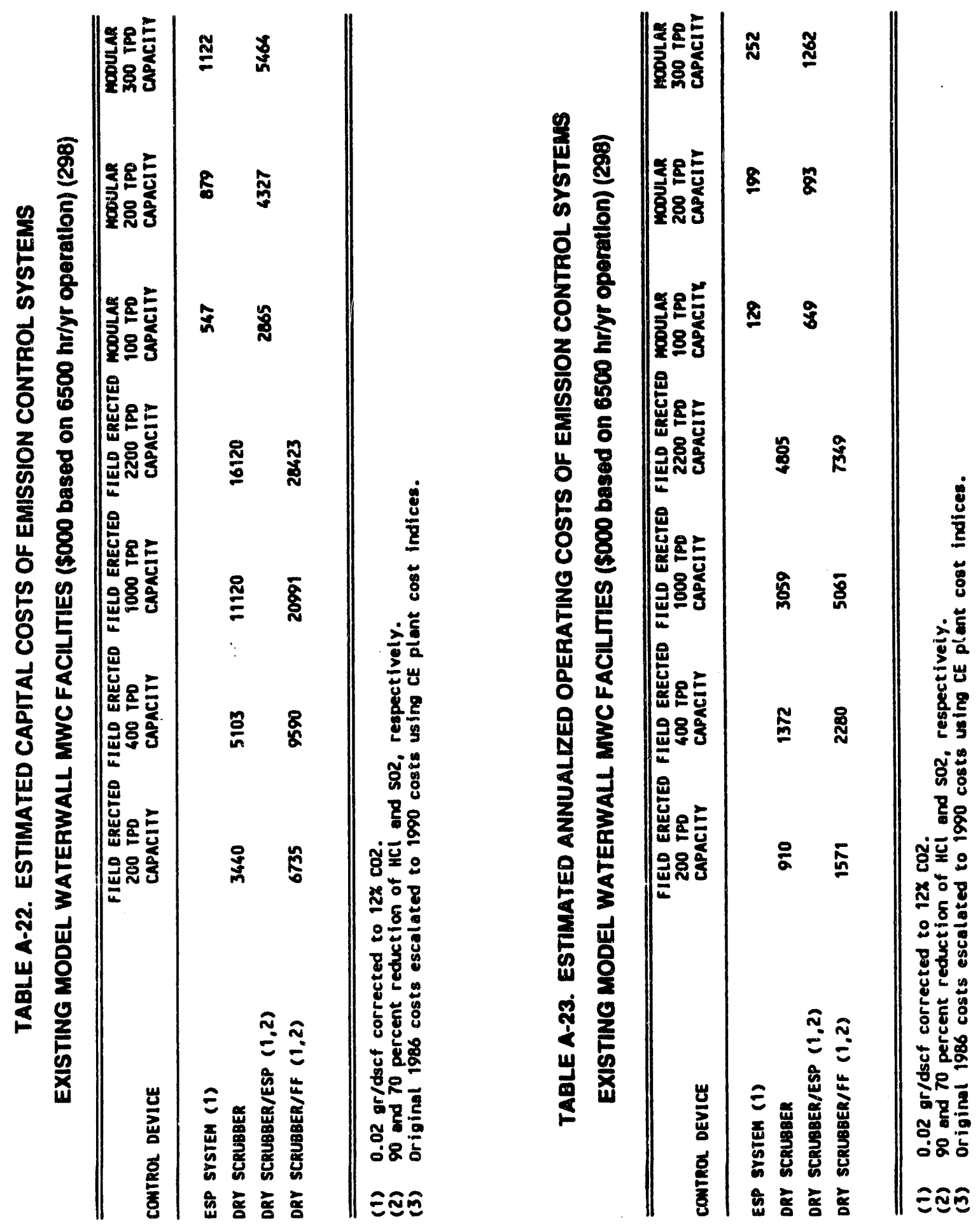
Tables A-18 and A-19 present caplital and operation and maintenance costs, respectively, for now model MWC factulies. The three types of ar pollution control included in these cost tabulations include electrostatic preciplators, in scoubbing with an electrostatic precipitator, and dry senubbing with a fabric filier. Costs are inctuded for three lovels of particulate matter omission: $0.03,0.02$, and 0.01 gr/dsct at 12 percent $\mathrm{CO}_{2}$. Further, costs are inctuded for field-erected tacilties ranging from 250 to 3,000 TPD and for modular faclltiles ranging from 100 io 400 TPD. As expected, the capltal costs and O\&M costs for each of the options increases as the desired particulate matter concentration in the exhaust aas bs decreased. However, this effect is much less pronounced with a dry serubberfiabric fiter system than for the other two options.

Tables A-20 and A-21 present capital and operation and maintenance costs, respectively, for model existing refractory MWC facilties. The four types of air pollution control included in these cost tabulations include electrostatic precipitators, dry scrubbing: dry scrubbing with an electrostatic precipitator, and dry scrubbing with a fabric filter. Costs, where available, are included for field-erected facilties ranging from 200 to 1,200 TPD and for a 100 TPD modular facility.

Tables A-22 and A-23 present capital and operation and maintenance costs, respectively, for model existing watenwall MWC facilties. The four types of air pollution control included in these cost tabulations include electrostatic precipitators, dry scrubbing, dry scrubbing with an electrostatic precipitator, and dry scrubbing with a fabric fitter. Costs, where available, are included for field-erected facilities ranging from 200 to 2,200 TPD and for modular facilities ranging from 100 to 300 TPD.

Kapner and Schwarz (218) compared the cost of a dry scrubberffabric filter emission control system versus a dry scrubber/ESP system for a facility consisting of three 350 TPD watenwall incinerators. Both systems were specified to meet a pollutant removal crtterion of 0.01 gr/dsct for particulate, and 90 percent removal of incoming hydrogen chloride and sulfur dioxide. Four vendors supplied cost estimates for the equipment, and all four priced their fabric fitter systems below their precipitators. The average cost for the fabric filter and precipitator systems quoted were $\$ 6.9$ million and $\$ 7.3$ million, respectively. Nearly 60 percent of the system cost was credited to the dry scrubber in both cases. The price differences between the two systems ranged from 1 to 9 percent. 
Kapner and Schwarz also compared operation and maintenance costs for the wo emission control systems. Data on both systems were obtained from vendor literature and from a survey of incineraior operators. The cost components included in the estimate were electricity, replacement parts such as filter bags, dry scnubber reagent, and labor for routine operation and maintenance. The estimated costs for the dry scrubberfiabric fther system were about 4 percent higher than for the dry scrubber/ESP system, at $\$ 906,000$ per year versus $\$ 875,000$ per year.

A comparison was made of the Flakd Dry Lime Adsorption System (DAS) versus the spray dryer (DRYPAC) for organics and dioxin removal (137). The capital cost comparison showed that the DAS is 8 percent less costly than the spray dyer system. A comparison of the O\&M costs indicated that the DAS is 12.5 percent less expensive than the spray dryer system.

NOx removal systems require a substantial capital investment. The capital cost of a selective catalytic reduction (SCR) system for NOx removal is estimated at approximately $\$ 3,000,000$ in 1990 dollars for a 1,000 TPD mass bum stoker fired facility (69). By way of contrast, an altemate, relatively experimental, method of NOx removal, the electron beam process, has a much higher capital cost of approximately $\$ 18,000,000$ in 1990 dollars for the same facility (69). The electron beam capital cost includes all costs for a complete system including a pre-scrubber and a fabric filter. An equipment scale up of 6:1 was required to calculate the estimated capital cost for the electron beam system because of hs relatively preliminary status, commercially.

The Thermal DeNOx system for NOx removal can be very cost effective if high NOx reduction is required. Typical costs for a two train 1,000 TPD MWC are estimated to be $\$ 385,000$ for equipment only, and \$800,000 including equipment, labor, overhead, construction supervision, all erection costs, engineering, and contingency (77). All costs are originally 1985 dollars escalated to 1990 costs using the Chemical Engineering Plant Cost Indices, and they are based on southem California labor rates. These typical DeNOx facility costs include one $120 \mathrm{~b} / \mathrm{hr}$ ammonia vaporizer, one 12,000 gallon liquid ammonia storage tank, injectors, piping, and instruments. The untreated flue gas is assumed to contain 230 vppm NOx at 12 percent carbon dioxide. The system is designed to remove $65 \%$ of the NOx. Table A-24 shows the annual O\&M costs for this system. 
TABLE A-24. ORM COSTS FOR THERMAL DONOX SYSTEM (TT)

1,000 TPD FACLITY - 1900 COSTS

\begin{tabular}{|c|c|c|c|}
\hline & $\begin{array}{l}\text { Annual } \\
\text { Use }\end{array}$ & $\begin{array}{l}\text { Unit } \\
\text { Cost }\end{array}$ & $\begin{array}{l}\text { Annual } \\
\text { Cost }\end{array}$ \\
\hline $\begin{array}{l}\text { NH3 } \\
\text { Camier Steam ( } 15 \text { pei) } \\
\text { Vaporizer Electrictly }\end{array}$ & $\begin{array}{l}482 \text { Tons } \\
27 \text { KTon } \\
158 \text { MWH }\end{array}$ & $\begin{array}{l}\text { S275/Ton } \\
\text { S13/Ton } \\
\text { S66MWH }\end{array}$ & $\begin{array}{l}\$ 132,000 \\
\$ 358,000 \\
\$ \quad 9,900\end{array}$ \\
\hline
\end{tabular}

All costs are original 1985 costs escalated to 1990

using the Chemical Engineering Plant Cost indices.

The costs of retrofitting the Olmstead County Waste to Energy Facilty in Rochester, MN with two systems for recucing NOx emissions were estimated and compared (535). Natural gas rebuming was compared with Themal DeNOx to determine its applicability as an altemative to Thermal DeNOx. Both systems are comparable in terms of capital costs with the rebum system being slightly higher at $\$ 594,000$ versus $\$ 564,000$ for the DeNOx system. If the additional steam produced in the rebum unit can be sold or used to generate electricity, then the O\&M, as well as the overall cost comparison, can decidedly favor natural gas burning (535). However, this analysis is heavily dependent on steam demand and natural gas and electricity costs. Moreover, MWCs are typically heat input limited systems. Therefore, it is unlikely, whthout derating the boiler, that a typical MWC system can realize the value of the proposed additional steam credit.

\section{A.4 MASS AND ENERGY BALANCE}

Figure A-11 shows the estimated mass and energy balances for a typical 550 TPD mass bum facility (716). The energy balance assumes the incoming waste has a higher heating value (HHV) of 5,000 Btu/b. Approximately 85 percent of the electricity produced is available for sale, with the remaining 15 percent used intemally. The ash is reported as 27 percent of the incoming waste stream on a wet basis after ferrous removal. 

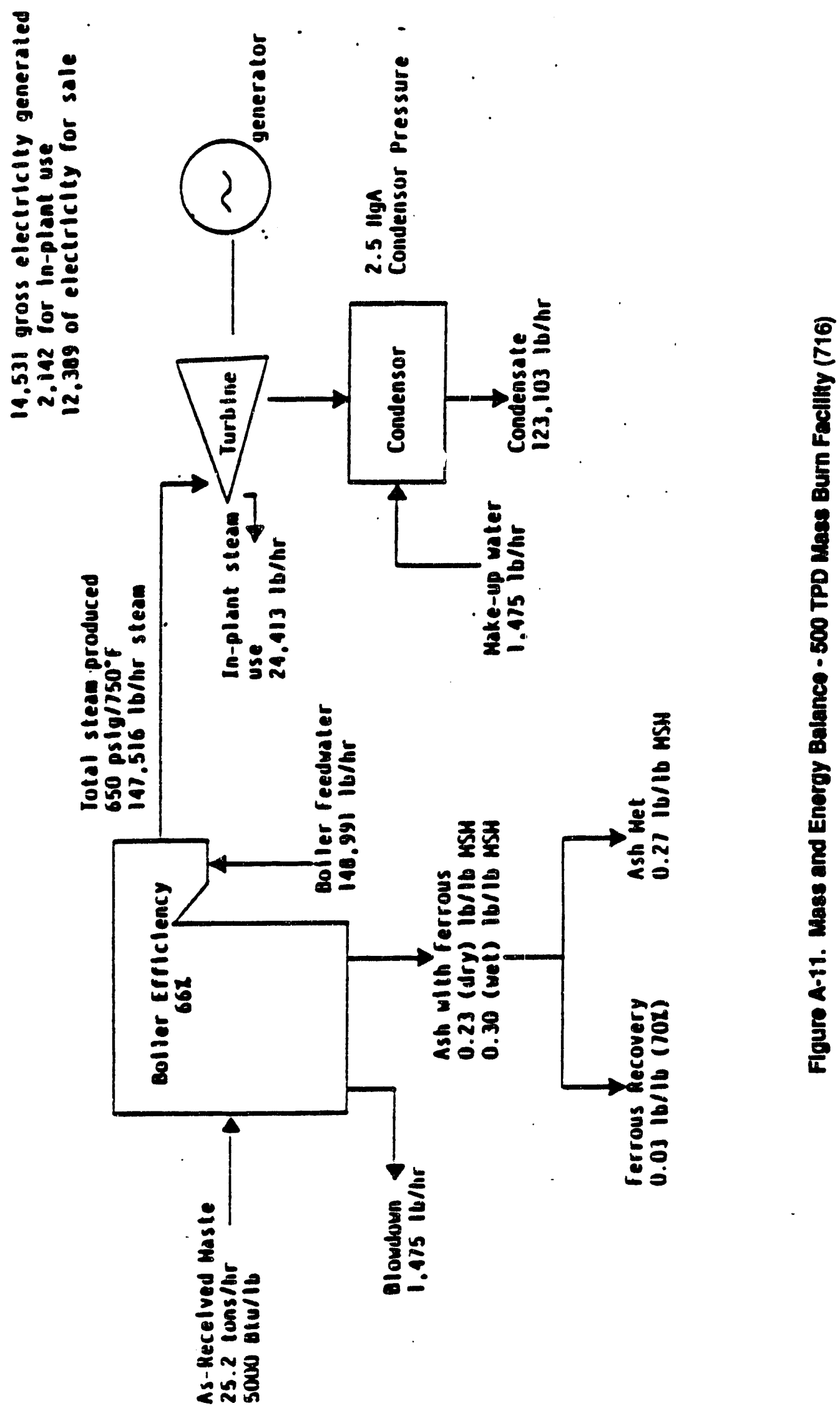
Figure A-12 shows the estimated mass and energy balances for the Monmouth County proposed 2,000 TPD maximum dally combustion capacty facilly (352). The eneroy balance assumes a HHV of 4,650 Btu/b for the incoming waste. Approximately 88 percent of the electricity produced will be avallable for sale; the remaining 12 percent is planned for internal use. The ash is reported as approximately 21 percent of the incoming waste on a wet basis. (A lesser amount of ash is expected because of the frontend processing system associated with this facillty which will rernove a major portion of the non-combustbles.)

Table A-25 shows typical energy bsses in both an excess air watenwall and a starved air modular municipal waste combustor assuming a fuel heating value of 5,000 Bturb.

TABLE A-25. TYPICAL LOSSES W REFUSE-FIRED BOILERS (255)

\begin{tabular}{|c|c|c|}
\hline & $\begin{array}{l}\text { Excess Air } \\
\text { Watenvall }\end{array}$ & $\begin{array}{l}\text { Starved Air } \\
\text { Modular }\end{array}$ \\
\hline Dry flue gas & $13.7 \%$ & $13 \%$ \\
\hline Evaporation & $13.5 \%$ & $12 \%$ \\
\hline Unbumed carbon & $0.7 \%$ & $3 \%$ \\
\hline Heat in ash & $0.6 \%$ & $1 \%$ \\
\hline Radiation, unaccountable & $1.9 \%$ & $6 \%$ \\
\hline
\end{tabular}

Assumes a fuel heating value of 5,000 Btu/bo

Table A-26 briefly summarizes the key process control and resultant energy recovery parameters for modular and field-erected mass bum systems. The specific process control parameters will depend on the energy user's requirements (e.g., fuel heating value, steam conditions, feedwater temperature, steam flow, and parasitic energy loads). While modular systems generally offer better economics at lower design capacities, the field-erected units are thermally more efficiont. Even though their shear size limits their ability to respond quickly to varying load demands, this characteristic, in addition to higher thermal recovery, also offers a "thermal inertia" to overcome short-term swings and ensure better bumout of combustibles. 


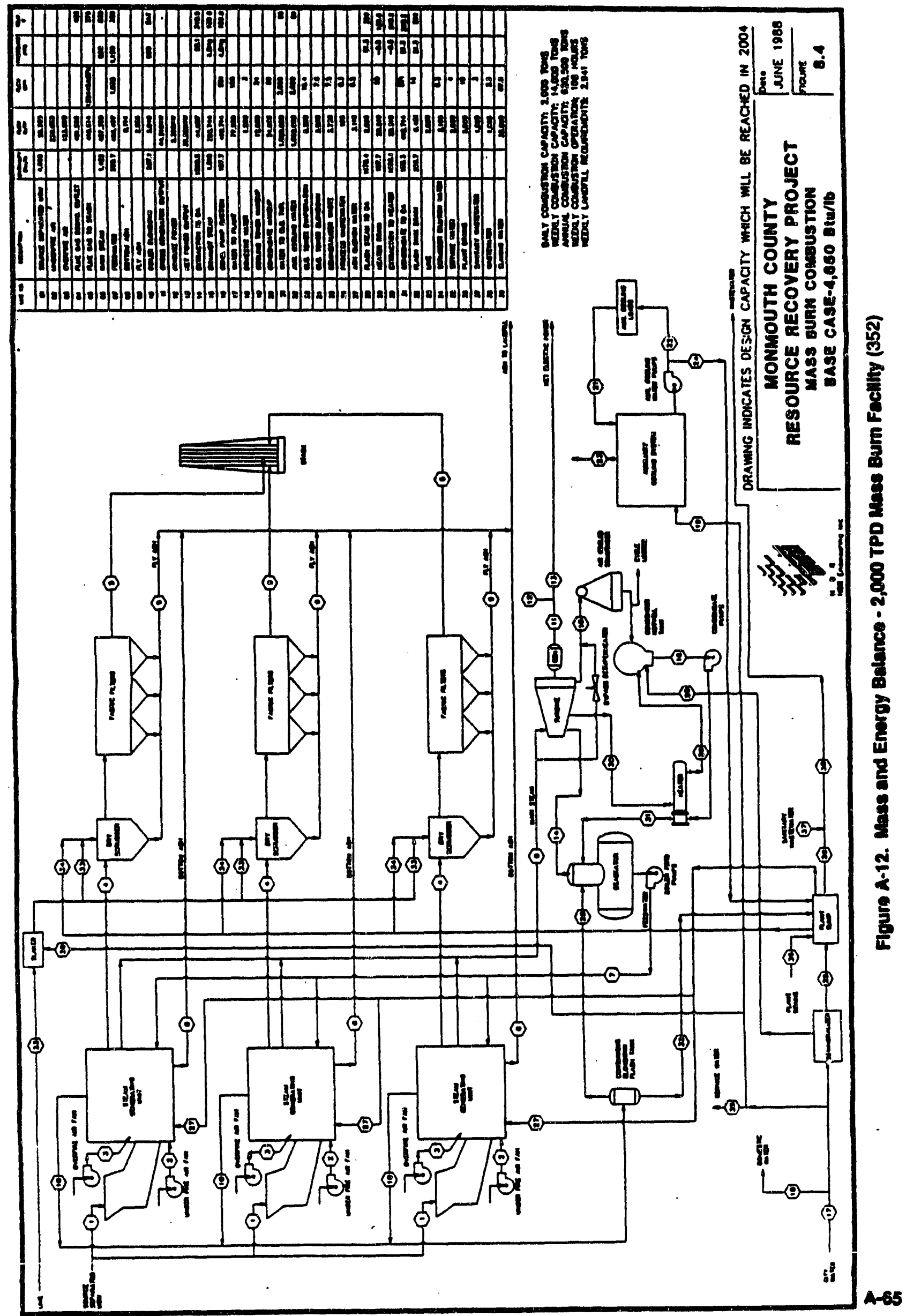


TABLE A-26. ENERGY RECOVERY COMPARISON

MODULAR VS FIELD ERECTED MASS BURN SYSTEMS (799)

\begin{tabular}{|c|c|c|}
\hline Description & Modular & Field Erected \\
\hline Higher Heating Value of MSW & 4,500 Btw/b & 4,500 Bturs \\
\hline Steam Conditions & 600/600 psigher & $625 / 755$ psig/of \\
\hline Feecwater Temperature & $300 \%$ & $300 \% \mathrm{~F}$ \\
\hline Boller Efficiency & $40-60 \%$ & $65-70 \% 11$ \\
\hline Gross Steam Flow & $\begin{array}{l}3,500-5,300 \text { bhon } \\
\text { recelved waste }\end{array}$ & $\begin{array}{l}5,200-5,700 \text { bhion } \\
\text { received waste }\end{array}$ \\
\hline Gross Electrical Output & 320 - 480 kWhtton & $520-570$ kWhMon \\
\hline Net Electrical Output & 290 - 430 kWhyion & 470 - 510 kWhrion \\
\hline
\end{tabular}

1) Watenwall fumace efficiency. Refractory fumace

efficiencies may be as low as $60 \%$.

Power production data for all types of mass bum facilities (387) is summarized in Table A-27. These data allow a comparison of the gross and net power output and kWhion. Because the data are limited, significant conctusions cannot be made. However, watenwall units have the ighest ratios indicating that they are the most efficient in terms of energy production. Attachment 11 provides detalled data for all of the field erected and modular mass bum facilities existing or in advanced planning in 1989.

TABLE A-27. RATIO OF NET/GROSS

POWER OUTPUT AND KWh/TON (387)

\begin{tabular}{|c|c|c|c|c|c|}
\hline & & Net & & Net & \\
\hline & Total & Gross & $\%$ & Power & $\%$ \\
\hline & No. & kWh $/$ & Reporting & Output & Reporting \\
\hline Watenwall & 75 & 0.87 & 25 & 0.83 & 93 \\
\hline Refractory & 5 & 0.67 & 20 & 0.73 & 40 \\
\hline Rotary & 20 & 0.76 & 30 & 0.83 & 90 \\
\hline Modular & 54 & 0.78 & 5 & 0.71 & 33 \\
\hline
\end{tabular}




\section{A.5 EMVIRONMENTAL RELEASESMMPACTS}

The major environmental reloases from a mass burn MWC are the air emissions discharged from the stack, the resicue discharged as bottom ash from the fumace and as fly ash from the air pollution control devices, and wastewater generated from facilty and equipment washdown, boller blowdown, and other miscollaneous uses.

\section{A.5.1 Air Emiseions}

The air emissions of greatest interest are the criteria pollutants listed in Table A-6 (Section A.2.5) for which New Source Performance Standards (NSPS) have been recently promulgated. These pollutants are particulate matter, carbon monoxide, organics (dioxins/turans), acid gases $\left(\mathrm{SO}_{2}, \mathrm{HCl}\right.$ ), and nitrogen oxides (NO and $\mathrm{NO}_{2}$, logether referred to as NOx). Other pollutants generated by the combustion of MSW include hydrogen fluoride and heavy metals - arsenic, beryllium, cadmium, chromium, lead, mercury, and nickel. Table A-28 presents summary data on emissions measured from mass bum systems with varying levels of air pollution control (APC) equipment and operating conditions. Acid-gas capture efficiencies for selected APC technologies are presented in Table A-29.

To achieve the designated pollutant removal efficiencies, municipal waste combustors (MWCs) are required to utilize Best Demonstrated Technology (BDT) -- state-of-the-art APC equipmem. Examples of systems in use at selected field-erected and modular mass bum facilities are as follows:

- Marion County OB. This Ogden-Martin facility, which began operations in late 1986, was the first U.S. waste-to-energy facility to use a dry scrubberffabric filter combination for air pollution control (387). It consists of two 275 TPD watenwall units. Each unit has a Teller-design spray dryer and fabric filter for acid gas and particulate emission control. Flue gases leave the boiler economizer and enter the bottom of the spray dryer through a cyclonic inlet for the removal of large particles. A slaked pebble lime reagent is mixed with water and injected into the spray dryer through nozzles at a lime to $\mathrm{HCl}$ ratio of 2.5 . A dry venturi follows the spray dryer, where Tesisortim material is injected to enhance the collection performance and reduce the pressure drop across the subsequent fabric filter. 


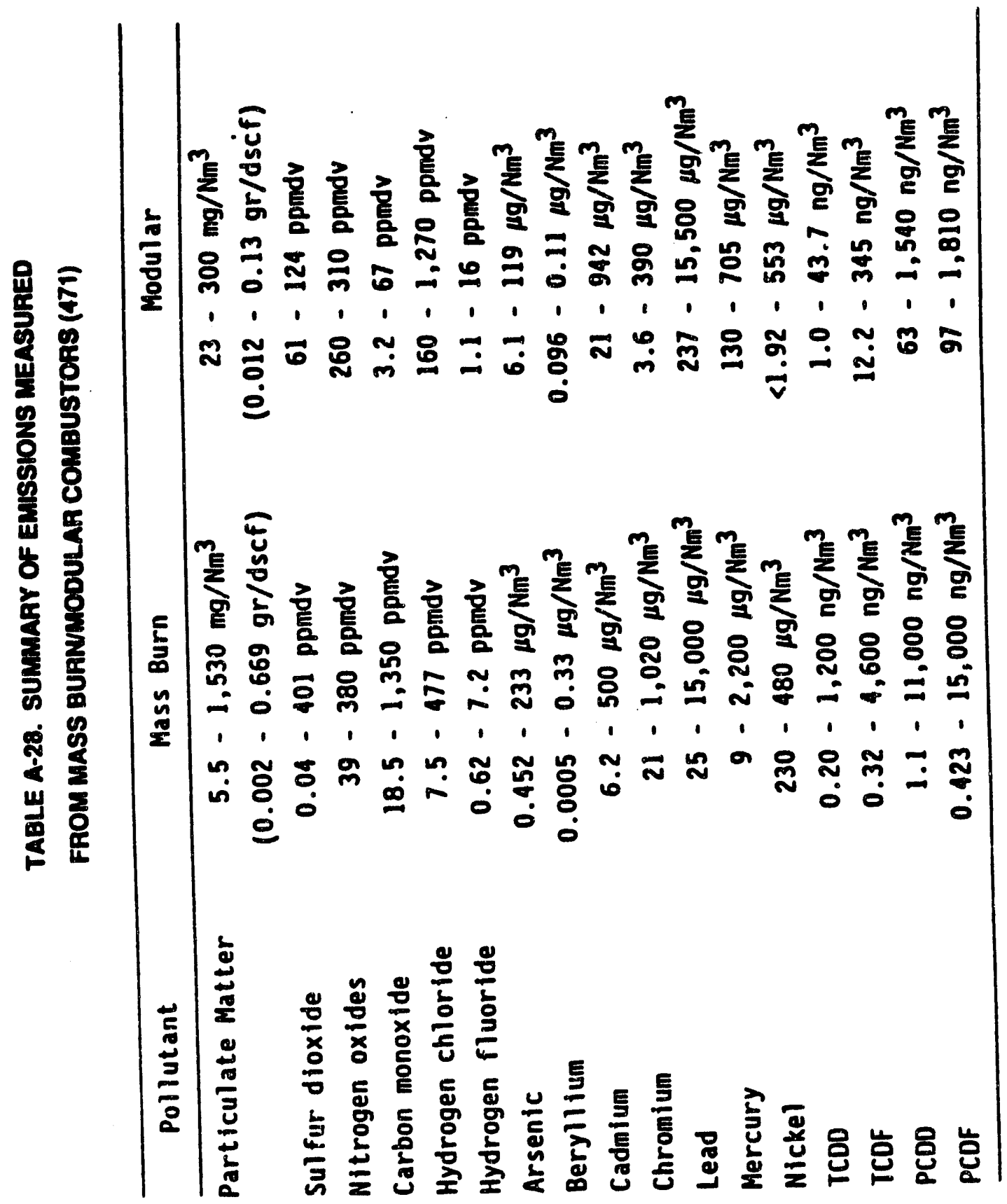


TABLE A-29. APC CAPTURE EFFICIENCIES (\%) (298)

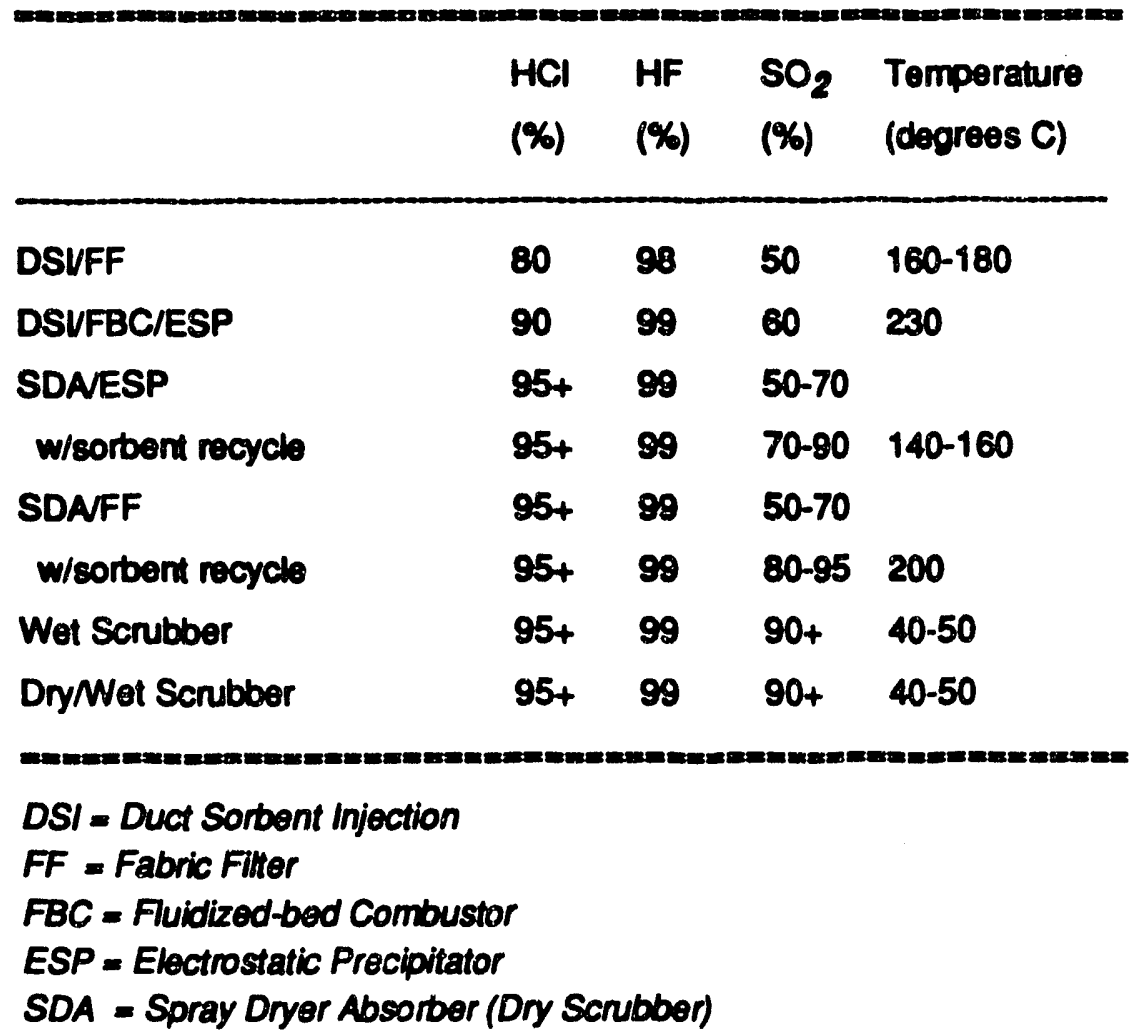

○

Long Beach CA. The SouthEast Resource Recovery Facility (SERRF), operated by Montenay, uses a Steinmuller grate/fumace, 650 psi750 degree F steam conditions, the gas recirculation to help reduce NOx formation, a spray dryer absorber by Flakt with 1.6 stoichiometry, a rotary atomizer, and a fabric fitter which uses a conservative 2:1 air to cloth ratio. Additional NOx control is by Exxon Thermal DeNOx, and the plant has a continuous online $\mathrm{HCl}$ monitor in the stack by Boden Seewerk (546).

- Dutchess County. NY. This Westinghouse plant, which stanted up in September, 1988, has two 200 TPD trains and a projected output of $8 \mathrm{MWe}$. It uses dry lime injection and a fabric filter for air pollution control. Dioxin emissions have been measured at 1.3 to 4.6 nanograms per standard cubic meter (ng/Nm3 from this facility. Carbon monoxide varies from 40 to $170 \mathrm{ppm}$ and NOx is about $100 \mathrm{ppm}$ (545). The combustion process requires only about 50 percent excess air, helping to reduce NOx formation (608). 
Bridoeport.CI. This Wheelabrator facility which utlizes the Von Roll and Babcock and Wilcox technology, began operation in July, 1988 (540). The plant has 800 psi840 degrees F steam conditions, three boller trains, and is rated at 2,250 TPD and 70 MWe. It uses a spray onyer absorber and fabric filter for air pollution control. The total solid particulate (TSP) stack emission is less than 0.0015 grains per dry standard cubic foot of gas (gr/dscf); almost an order of magnitude loss than the most stringent now source performance standards. Dioxin data has been measured as $0.01,0.012,0.067$ micrograms per standard cubic moter (ug/ $\mathrm{Nm}^{3}$ ), which is 10 to 67 nanograms per standard cubic meter.

Skagit County W/A. This Technochem Environmental Systems' facilty, stanted up in 1989, has two lines for a 178 TPD total capacity. The units are rotary kilns with secondary chambers, and utilize Teller type (Research-Cottrell) spray-dryer absorbers and fabric filters using hydrated lime. The spray dryer absorber sprays lime in a water slumy into the flue gas with the objective of reacting with the acid gases, capturing the sulfur and chlorides as relatively harmless salts. The plant has one 2.5 mogawatt electric output furbine, using 450 psi saturated steam conditions (541).

For new facilities, BDT has been determined to be a fabric fitter for metals control, a spray dryerfabric filter for acid gas control, and selective non-catalytic reduction for NOx control. The Commerce, CA 400-TPD facility uses this technology and claims to have the most modem air pollution control system of any MWC in the world (636). Designed by Foster-Wheeler, the Commerce facility utilizes a Detroit reciprocating grate. It produces $11.5 \mathrm{MWe}$ from 5,500 to 6,000 Btu per pound of commercial waste. The Commerce facility uses the following air pollution control equipment and practices:

- Exxon Thermal DeNOx ammonia injection system for NOx control

- Teller dry scrubber with wet lime injection for acid-gas control

- Research-Cottrell reverse air baghouse for particulate control

- A roughing cyclone captures 90 percent of the total solid particulate (TSP) before the Teller spray oryer absorber 
- Building air is used as combustion air to control odors

- Combustion temperatures are maintained above 1800 degrees $F$ to minimize dioxin and related emissions

Emissions from this plant are among the lowest reported from U.S. MWC8 (472). The system was designed for control efficiencies of 20 to $50 \%$ for NOx, 90\% for SOX, and $95 \%$ for $\mathrm{HCl}$ (37). Table A-30 summarizes the air emission removal efficiencies achieved at the commerce facility. The removal efficiencies were calculated from average measurements made with and without air pollution control. Testing was not simultaneous, and therefore actual removal efficiencies may vary from those shown.

TABLE A-30. AIR EMISSION REMOVAL EFFICIENCIES

AT THE COMMERCE, CA FACILTY (636)

\begin{tabular}{|c|c|}
\hline Component & $\begin{array}{c}\text { Removal } \\
\text { Efficiency, \% }\end{array}$ \\
\hline NOx & 44.5 \\
\hline sox & 99.5 \\
\hline Particulate & 99.8 \\
\hline $\mathrm{HCl}$ & 98.8 \\
\hline Dioxins/Furans & 95.2 \\
\hline Antimony & 97.6 \\
\hline Arsenic & $>98.8$ \\
\hline Beryllium & $>88.4$ \\
\hline Cadmium & $>99.8$ \\
\hline Chromium & $>98.8$ \\
\hline Copper & $>99.9$ \\
\hline Lead & 99.9 \\
\hline Mercury & 0 \\
\hline Nickel & 294.9 \\
\hline Selenium & $>89.4$ \\
\hline Silver & $>96.9$ \\
\hline Thallium & $>70.1$ \\
\hline Zinc & $>99.9$ \\
\hline
\end{tabular}


Risk assessments were performed for eleven planned facillites in 1985 (439). The facilities ranged in size from 500 TPD to 3,000 TPD, and all planned on installing ecrubbers and high-efficiency ESPs or baghouses. The risk assessments were based on exposure via various pathways such as inhalation, ingestion and dermal contact with contaminated solls, and the tood chain. Although the determination of acceptable risk levels is very subjective, the historical actions of regulatory and health agencies which pertorm and reviow health assessments have resulted in guidelines which have been adopted in the industry. A maximum individual cancer risk of 1 case per million people exposed is normally considered to be an insignificant risk, while risk levels from 1 to 10 cancer cases per million people exposed is considered to be an acceptable risk. These risk lovels assume that all reasonable means to reduce risk have been adopled. The cancinogenic risks of MWC emissions are considered to be greater than the non-carcinogenic risks, and the risks due to ingestion and dermal contact exceed those from inhalation.

All eleven of the planned facilities had estimated health risks that were within the acceptable range of 1 to 10 cancer cases in one million exposed people. These estimates included the cumulative risk from all sources and exposure pathways considered in the analysis. The practice of accumulating the individual risks is reported to result in an overestimation of the actual risk and is thus a conservative methodology (373). A health risk assessment for the Ogden Martin facilty in Stanislaus County, Califomia, showed that the actual average emissions were much lower than the maximum permitted emission lovels based on health risk assessment estimates (537). The actual values ranged from 1 percent to 68 percent of the permitted vatues. The carcinogenic risk based on these average values is considered to be insignificant.

Health risks are in 10,000 to 1 in 100,000 for existing MWC facilities (interpreted to mean those facilities having only a relatively inetficient particulate control device for APC) and 1 in 100,000 to 1 in $1,000,000$ for new facilities (interpreted to inciude those with acid gas scrubbers and subject to new source performance standards) (298).

\section{A.5.2 Wastewater Dlscharge}

The sources of wastewater discharge from a mass bum facility include the following (348):

- Continuous and intermittent blowdown

- Equipment and facility washdown

- Pretreatment filter backwater

- Demineralizer-neutralized regenerate 
- Quench water

- Sile drainage

- Sanitary water

Wastewater from blowdown, pretreatment filter backwater, and demineralizer-neutralized regenerate is considered to be clean wastewater and therefore can be used as washdown water. Washdown water, be clean water or recycled wastowater, is typically piped to a sump where solids are settled out. The supernatant is then pumped to the ash quench tank.

Water loss from the quench tank is due to evaporation and absorption by the residue. Evaporation is a function of the amount of floating solids in the quench tank: the more solids the less evaporation. The ashresidue discharged from the quench tank is typically 30 percem water by weight, resulting in a significant amount of water loss by absorption. This type of water loss is estimated at about 2,500 gallons per day (GPD) for a 100 TPD facility and 12,500 GPD for a 500 TPD facility (636).

If the pretreatment filter backwash water and the demineralizer-neutralized regenerate are not used for quench water or other intemal use, they are normally discharged to the sewer. Site drainage and sanitary wastewater are normally not a problem and are handled in the normal manner.

\section{A.5.3 Ash Besidue}

The impending Resource Conservation and Recovery Act (RCRA) reauthorization may specify or mandate the development of treatment, utilization, and disposal criteria for incinerator ash. The type of ash (i.e., botiom ash, fly ash, or combined) can determine the extent of treatment or the type of disposal required. Fly ash usually contains higher concentrations of metals than bottom ash, and therefore may require more rigorous treatment or handling.

Under RCRA, all wastes are categorized as either hazardous (Subtitle $\mathbf{C}$ waste with fairly stringent and costly requirements) or nonhazardous (Subtitle D waste). The confusion over the regulatory status of MWC ash arises from conflicting interpretations of the household waste exclusion provision of RCRA (897). It states that buming only municipal waste in MWCs is not managing hazardous waste; however, it makes no mention of the ash produced. One interpretation maintains that the household waste exclusion also applies to MWC ash; another views that tha subject ash is not included and if it fails ash testing it should be regulated as hazardous. 
The U.S. EPA has taken different positions over the past few years regarding its interpretation of the intert of Congress on this subject. With no current formal postion, is now llkely that EPA will defer to legislative action when Congress reauthorizes RCRA (897, 898). Also during this time, environmental groups have sought a judicial resolution of the household waste exemption. In lawsults filed in Chicago. Illinois and Westchester County, New York, Judpes nuled that Congress had in fact exempted waste-to-energy plants from the requirements of RCRA Subtitle C. However, the U.S. Court of Appeals for the Seventh Circult in Chicago, reversed the earlier decision, now nuling that MWC ash is subject to RCRA Subtille C (899). This reversed decision conflicts with an uphold decision issued by the Court of Appeals for the Second Circuil located in New York City (900). Judicial action is likely to continue.

In addition to ash classification, ash residue testing is the other major issue in the ash controversy. The judicial challenge posed by environmental groups sought to force MWC facilities to test their ash for hazardous components and dispose of it as a hazardous waste, necessary (898). However, nowhere in the RCRA regulations is there an explich requirement that all waste generators test their wastes to determine if those wastes are hazardous. What the regulations do say is if the waste is not exempt from Subtitle $C$ and is not already listed as a hazardous waste, then the generator must determine if the waste exhiblis a hazardous characteristic. Once again, the uncertainty arises over the question of whether or not MWC ash is exempt from RCRA Subtitle C regulation (897).

Section 3001 of RCRA states that to be hazardous, a waste must be either listed specifically as a hazardous waste or exhibit characteristics of being ignitable, corrosive, reactive, or toxic. The only tests potentially applicable to ash are comosivity (although, the PH of MWC ash gsmaraily falls within acceptable ranges), and the Toxicity Characteristic Leaching Procedure (TCLP), which replaces the former EP Toxicity test.

The TCLP is intended to simulate the leaching of toxic constifuents found in MSW into the environment when co-disposed in a sanitary landill. If after the waste in question is sieved and agitated with various extraction fluids, the resulting leachate equals or exceeds levels established for 40 constituents (listed in Table A-31), the waste is classified as hazardous (901). [(t should be noted that TCLP incorporates all of the EP constituents, and the dilution attenuation factor (DAF) of 100 relates to fate and transport modeling based on the federal drinking water standards.] While TCLP is generally viewed as an improvement over the EP Tox test, the TCLP test suffers from difficulty in obtaining a representative sample, variability of testing procedures among laboratories, and relatively high cost. The accuracy with which TCLP or any antificial laboratory can predict actual leaching from ash in a landill has boen questioned (898).

WTO CORPORATION 


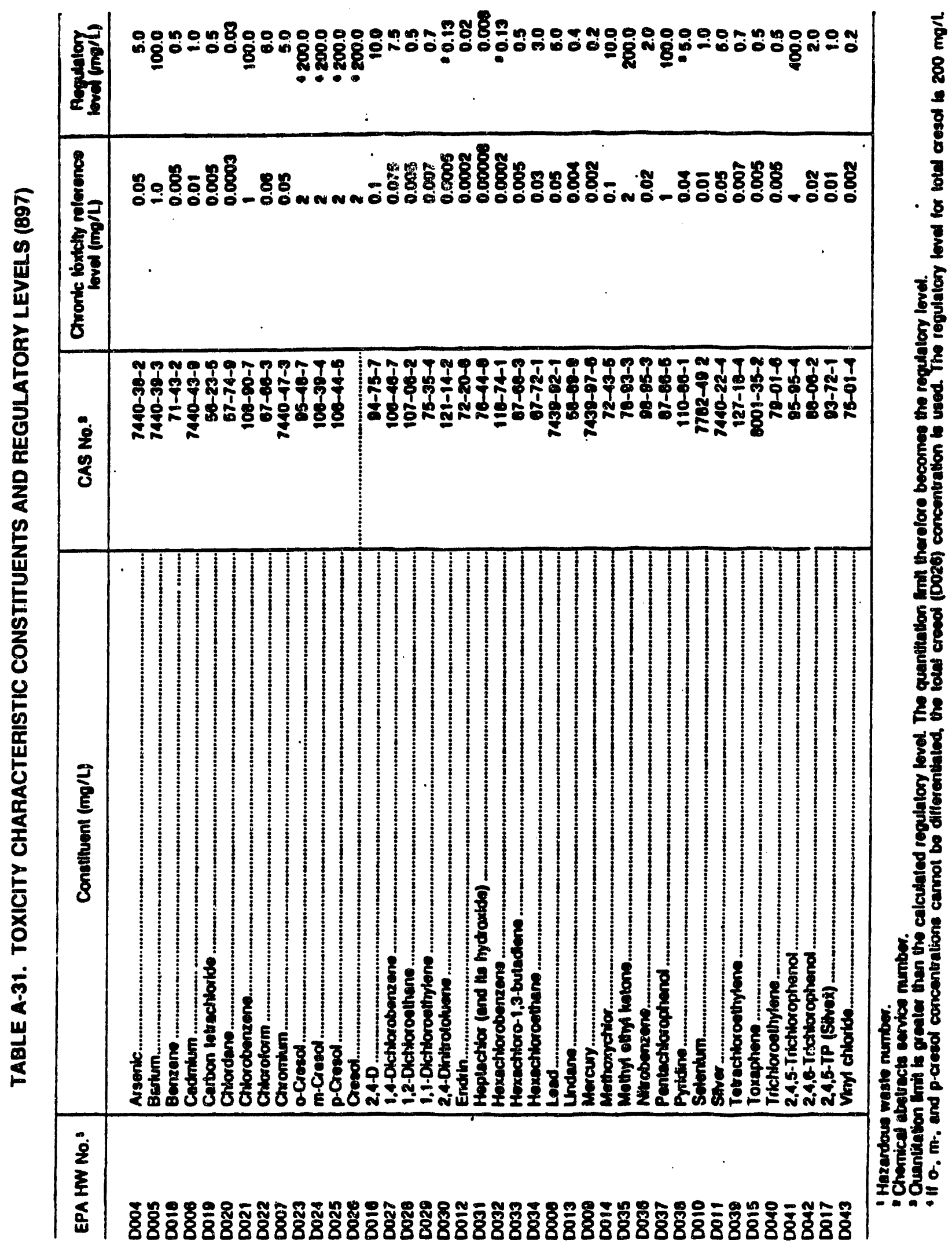


Whereas, for now, MWC ash is not classlfied at the Federal lovel, many states have establishod their own standands. Table A-32 summarizes states' requirements reganding ash testing (elther EP Toxicity, TCLP or other state-approved procedures), disposal, and ash utlization standards (898).

\section{A.5.3.1 Landiill Dlanosal}

The simplest method of residue handing is the landilling of untreated ash. In the case of co-disposal in a municipal solid waste landfill, the chemistry of MSW has been reported to be such that when combined with untreated thyash, It tends to accolerate leaching of the motals in the thash. Because of this, dedicated ash monofills have boen developed in recent years for the disposal of MWC ash (217). Conversely, a Florida study found that there are no significant differences between the leachate characteristics from a mixed disposal facility and from an unprocessed solid waste landill (825). A survey of 15 states showed that 11 of the 15 required monofills for incinerator ash while only 4 allowed co-disposal of ash and MSW (825).

\section{A.5.3.2 Ireatment}

Most ash treatments attempt to lower the leachable metal and salt concentrations and thus render the ash more environmentally acceptable. If the environmental aspects of the ash can be improved to within acceptable limits, the ash can possibly be utilized for a variety of purposes. Ash treatment processes are currently in all stages of development: available, in the patent stage, and under development. The treatments currently being considered or marketed include (825): ferrous metal separation, chemical extraction, compaction, solidification/stabilization, phosphate addition, and vitrification.

A.5.3.2.1 Eemous Metals Separation. Because mass bum facilities typically do not have any front-end separation, their bottom ash contains approximately 15 percent ferrous metals (825). Many field erected mass burn facilities recover ferrous metals from the ash, yet few modular facilities do so. As of 1989, 61 percent of the 70 existing field erected facilities recovered ferrous metals from the ash while only 4 percent of the 50 existing modular facilities recovered ferrous metals (387).

A.5.3.2.2 Chemical Extraction. Chemical extraction is presently under development and is not available for full scale application. Hydrochloric acio has been used in the laboratory to remove up to 98 percent of the cadmium and 70 percent of the lead from a combined ash sample (825). The projected high costs of this process may limit its use to thy ash only. The estimated costs are from \$20/ton for salt removal to s80non for heavy metals extraction and recovery (825). 


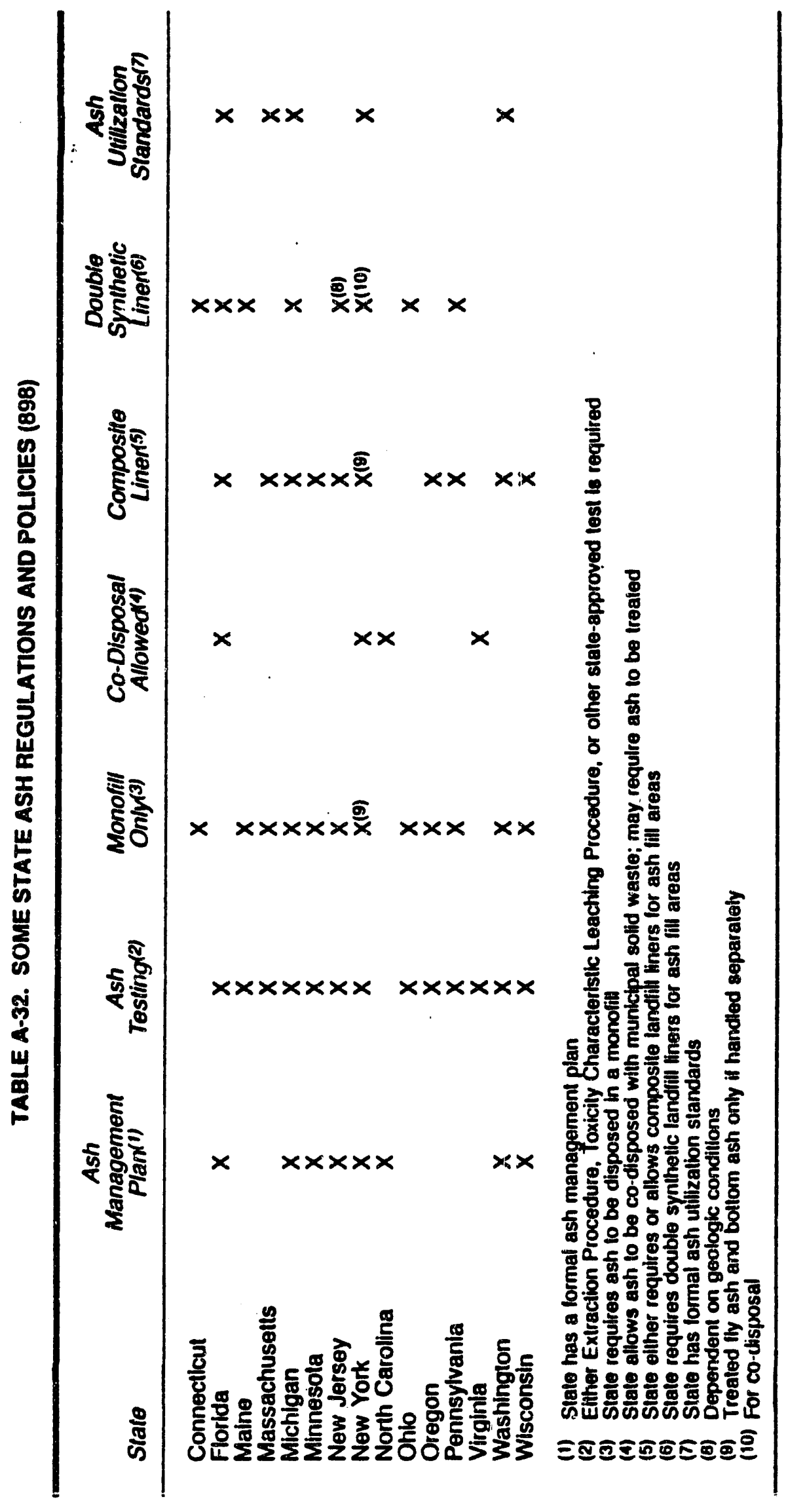


A.5.3.2.3 Compaction. Wheolabrator Environmental Systems is experimenting with bottom ash compection at their monofil in Saugus, MA. A technique for ash compaction has been establishod and paterted in which densities of over 3,300 pounds per cublc yard are achieved. The permeability of the compacted ash has boen measured to be from $1 \times 10^{-6}$ to as bw as $1 \times 10^{-9}$ centimeters per second, comparable to or better than the typical landfill liner requirement of $1 \times 10^{-7}$ centimeters per second (825). To prepare the ash for use as a landifl uner, Portland cement can be added in situ at 6 to 10 percent by weight, and lime at 6 to 7 percent by weight. The economics of using a 10 percent Portland cementash mixture as a liner are very favorable at approximately $\$ 50,000$ per acre compared to synthetic or clay liners at $\$ 250,000$ to $\$ 500,000$ per acre $(321,361)$.

\subsection{Sollifileatlon/Stabllization. Ash solidification or stabilization (S/S) can be} accomplished by a variety of chemical methods. Most involve mixing a pozzolanic matrix such as Portland cement, cement kiln dust, or lime with the ash. The resulting monolithic structure and alkalinity reduce the release of contaminants in the ash. Portland cement mixed with ash produces a physically durable product when combined ash is used. When Portland cement is mixed with thy ash alone, the product has poor physical properties (359). The solidified cement/ash mixture can be used to fabricate masonry blocks or as a road base material.

The Japanese have developed a flue gas neutralization system for the removal of heavy metals from fly ash $(532,591)$. The process consists of dissolving the thy ash in quenching water and then neutralizing the solution with carbonic acid from the combustor exhaust gas. The neutralization process transtorms the heavy metals into inactive insoluble carbonates. This process is similar to phosphatizing. Electrical power requirements are reportedly approximately $44 \mathrm{Kw} / \mathrm{hon}$, and water requirements are about 116 galnon. This process has only a few actual applications in Japan. No practical use tor the neutralized ash has been discovered.

The Japanese reportedly have many actual applications of the fly ash solidification process (532). They claim that the process is simple and is very effective in fixing heavy metals. Power consumption is estimated at $33 \mathrm{kw}$ ton, and about 364 pounds of cement per ton of ash are required. The mixture is weak just atter molding, requiring curing equipment.

The U.S. EPA initiated the Municipal Waste Innovative Technology Evaluation (MITE) program to evaluate the physical, chemical, and leaching properties of treated and untreated MWC ash (358). Four commercial stabilization processes consisting of a cement based process, a silicate based process, a cementkin based process, and a phosphate based process were investigated. The MWC resicue 
tested was collected from a stato-ofthe-an MWC that consisted of a primary combustor with vibratory orates, a secondary combustion chamber, a boller and economizer, a wet/dy scrubber (spray drier) with lime, and particulate recovery using tabric fimers.

The Toxichy Characteristic Leaching Procedure (TCLP) test protocol was used to evaluate the treated and untreated residue. All untreated bottom and combined ash samples passed the TCLP, whereas untreated air politution control (APC) system residue consisting of thash and spent scrubber sorbent failed the TCLP for barium, lead and mercury. The addition of Portland cement alone, and with additives such as silicates and polymers, allowed the APC residue to pass the TCLP, with the exception of barium (358).

Further results showed that the treated residue from all processes evaluated performed poorty in terms of the curability tests (359). APC residues apparently are not amenable to the processes evaluated because of a high release of salts (358). Since 30 to 50 percent of thy ash is salt, this high salt content can reduce the strength of the resulting material if pozzolanic fixation is used (591). Final test results from this program are expected to be published in late 1991.

Cement based solidificationstabilization processes offer the following potential advantages (824):

- Solidification can significantly reduce the rate of release of insoluble contaminants

- The amount of cement can be varied to produce high strength mixes, making the mixture a suitable subgrade material

- Cement mixing is a well known technology, and no specialized labor is required

- The leaching characteristics of the resulting product can be improved by coating the material with a sealant

The main disadvantages of cement based solidification are a result of the presence of impurities such as organic materials, sitts, clays or salts (824). These impurities can delay the setting and curing of the Portland cement for several days and, in the case of salts, render the process ineffective.

MWC ash may also be stabilized by means of the circular fluidized-bed (CFB) technology. Preliminary tests on ash from a Scandinavian CFB indicate remarkably low toxiclty, with fly ash less toxic than bottom ash (435). This could be due to waste composition; additional testing is needed. The 
manufacturer of the CFB claims that the fing gas residence time of the CFB technology allows ash metals to bond tenaciousty whth bed sand and limestone while circulating through the furnace, therefore recucing the leaching characteristics.

A.53.2.5 Phosphete Addition. A commercial phosphate based process has been doveloped and patented by Whoelabrator Environmental Systems (825). Commercially known as "WES-REAlix", this system reportecly reduces the lead and cadmium solubility in MWC ash. Phosphate is infecto the ash to bind the motals in a chemical matrix. Both bottom ash and fly ash can reportidy treated successfully with this technology. Four of Wheolabrator's faciltiles have been equipped with WES-PHix systems.

A.5.3.2.6 Ylutifiention. Ash fixation can also be accomplishod by ash melting, also called vitrification. This technology consists of a fusion process in a 2600 degrees $F$ kiln for the purpose of binding contaminants in an alumina-silicate matrix (825). The resulting matrix can be ground into a course grit-like material. Vitrification can reduce the volume of ash by at least 60 percent while rendering the product very resistant to metal leaching. There are presently two major disadvantages of vitrification as a means of ash stabilization, its cost and the release of constituents during the vitrification process. The very high temperatures required by the process can result in the vaporization and release of constituents such as heavy metals and chlorides. Air pollution control equipment must be provided to remove this secondary residue from the process. The cost of ash vitritication is extremely high at $\$ 100$ to $\$ 200$ per ton of ash treated (825).

The Japanese have investigated ash vitrification and report that it is "perfect" except for problems with the respreading of heavy metals and the disposal of salts not hardened (591). The Japanese also have designed a systern in which fly ash can be vitrified with an electric arc (532). This system is at the demonstration level. Approximately 10 percent of the fly ash treated forms a molten salt which requires additional treatment prior to disposal. Also requiring treatment is the exhaust gas stream, which collects heavy metals during the process. The resulting material can be used as backfill or road-bed material. Power consumption is estimated at 880 to $1300 \mathrm{kw} /$ Ton of treated ash.

At the Japanese Takuma facility in Sohka, bottom ash is vitrfied to prevent heavy metal leaching at the landfill (273). The ash is reduced in volume to one third of its original displacement. Ash remelting is accomplished using an oil-fired furnace that heats the ash to approximately 1300 degrees $C$. The process costs $\$ 118$ per ton of ash, or $\$ 18$ to $\$ 27$ per ton of refuse ( 1987 dollars). (273) 
Another ash vitrification process, developed in the U.S. (503), features a large kiln fired with natural gas and liquid fuels, and supplemented with a natural gas/oxyoen lance, followed by a pudding fumace, oxidizers, and spray dryer and fabric fllter. The gases from the combustion process cause the ash feed to mell and the stag material is discharged from the oxidizer and cooled to produce approximately 100 TPD of aggregate. H the MWC produces olectricity, an electrode may replace the gas/oxygen lance.

High temperature coment kiln technology has also proved successful in utilizing ash residue from the direct combustion of RDF in the production of cement. Bue Circle Inclustries (BCI) has been using RDF as a supplemental fuel in the commercial production of cement in England since 1980. One cement kiln operating at BCl's Westbury U.K. Plant (271, 902) relies on the insuffiation of essertially poundered RDF into the kiln at 2600 degrees F. The high temperature and long residence time in the kiln provide complete combustion of the RDF, while the limestone used in cement manufacture provides a bullt-in acid gas scrubbing action. The RDF ash is compatible with and becomes a supplemental raw material for the cement product. Altematively, this technology can accept the ash and combustion products from extermal RDF combustion units (903).

Penberthy Eloctromelt Intemational, Inc. offers a system to vitrify MWC ash using an electric molten glass fumace (858). The system uses resistance heating with no arc and an oxidizing atmosphere. Electric melting is by resistive conduction through the molten glass, which is quiet and gives off no fume or dust. The onty offgases are carbon dioxide from the limestone and water vapor, at low temperature. Chlorides and sulfates are claimed to be retained in the glass. If the ash does not include lime from an acid gas scrubber, It may be necessary to add small amounts of soda or lime to insure the proper "mix" to produce glass. Each fumace is rated at 50 TPD.

\section{A.5.3.3 Uses of Ash}

Incinerator ash is being considered for use as landfill cover, as aggregate for use in road base construction, and as aggregate for use in masonry block fabrication. Atthough incinerator ash appears to have potential for uso in construction materials, the long-term liability of using an ash-based construction material is unknown (197). Studies are still trying to assess any long-term effect ash-based construction materials may have on the environment. Table A-33 lists examples of the currently envisioned atternative uses of ash. 
LANDEILLCOVER

Pinellas Cty, FL

BOAD AGGREGATE

Houston, TX

Puente Hills, CA

Tamps, FL

McKay Bay, FL

Yokahama, Japan

ABTIFICIAL REEFS

Stony Brook, NY

Pinellas Cty, FL

MASONAYBLOCKS

Stony Brook, NY

WTO CORPORATION
Ash is processed to prepare an agoregate material. Has used the ash agoregate for landfill cover, as a substitute for limerock in road bases, to stabilize sandy or muddy areas, and to construct berms since $1983(360)$.

In 1975 FHA tested a bituminous concrete made with 89 percent bottom ash aggregate maximum 1" in size, 9 percent asphalt, and 2 percent hydrated lime. The road exceeded stability and flow criteria for medium to heavy traffic (824).

Plans are undenway to constnuct 15 acres of roads and tipping areas with a mixture of aggregate and asphall at a landfill. Ash will be screened to 1", mixed with Portland cement, and broken into gravel. In process of obtaining permits (824).

Test street - aggregate contained 15 percent treated ash. Rosults promising, but limited test data (723).

Mixture of bottom ash and Portland cement is being marketed as "McKayanite" by private contractor. Used in the construction of a commercial parking area (360). Another private contractor is marketing a soil-cement substitute called "Permabase" made from bottom ash (360). This material has been used in various projects throughout Florida.

Prepared an incinerator gravel product consisting of 38.4 percent glass, 13.1 percent ceramics, 10.2 percent pebbles, 3.5 percent non-ferrous metals, 10.7 percent other materials, and 24.1 percent materials less than $5 \mathrm{~mm}$ in size. Consider this an appropriate material for use as a lower subbase course material in road construction. A total of 125,994 metric tons of this material has been utilized in the construction of 66 roadways from 1983 through 1987 (592).

Constructed two reefs in 1987, one as a ountrol and one from a cementash mixture. Blocks were 65-75 percent crushed combined ash, 15 percent Portland cement, and 10-20 percent sand. Have performed extensive leaching tests and found no leaching of ash contaminants to date. The cement/ash blocks have maintained their structural integrity better than the control blocks (824).

Conducting research on manufacture of artificial reefs from mixtures of ash and Porlland cement (360).

Constructed a boat house from blocks manufactured with 67 percent ash and 13 percent sand aggregate. Blocks are being continuously monitored for structural and environmental integrity, the interior air quality is being continuously monitored, and the surrounding soil is being tested for leached contaminants. Also considering the sie of cement/ash blocks for use in the construction of coastline erosion con, I barriers (824). 


\section{APPENDIX A。 MASS BURN TECHNOLOGIES \\ REFERENCES}

017 Hasselriis, F., "How Control of Combustion, Emissions and Ash Residues from Municipal Solid Waste can Minimize Environmental Risk, " Resource Recovery of Municipal Solid Wastes. AIChE Symposium Series, no. 265, vol 84, P.J. Knox, ed, AIChE, 1988, pp. 154-167.

020 Rigo, H.G. and A.D. Conley, "Weste-to-Energy Facility Capital Costs," Proceedings of ASME National Waste Processing Conference, Philadelphia, PA, May 1988, Pp. 23-28.

025 Velzy, C.0., "Incineration's Role in Integrated Solid Waste Management," Integrated Solid Waste Management, Options for Legislative Action, F. Kreith, ed, Genium Publishing Corp., 1990, pp. 103-120.

026 Beckman, A. H. and D.R. Spahn, "Dry Lime Injection for Acid Gas Control in Municipal Waste Incinerators," Air \& Waste Management Association 82nd Annual Meeting. Anaheim, CA, June 1989.

027 Brna, T.G., "State-of-the-Art Flue Gas Cleaning Technologies for MSW Combustion," Resource Recovery of Municipal Solid Wastes, AIChE Symposium Series, vol 34, no. 265. P.J. Knox, ed. AIChE, New York, NY. 1988.

028 Brna, T.G.and J.D. Kilgroe, "The Impact of Particulate Emissions Control on the Control of Other MWC Air Emissions," J. Air \& Waste Management Association, September 1990, Pp. 1324-1330.

029 Dhargalkar, P.H. and J.T. Zmuda, "Dry Scrubbing Systems Experience in Resource Recovery Applications," Air \& Waste Management Association 82nd Annual Meeting, Anaheim, CA, June 1989.

030 Donnelly, J.R. and K.S. Felsvang, "Low Outlet Temperature Operation for Resource Recovery SDA Emission Control Systems," Air \& Wast tanagement Association 82nd Annual. Meeting, Anaheim, CA, June 1989.

031 Donnelly, J.R. and K.S. Felsvang, "Joy/Wiro SDA MSW Gas Cleans, gystems New Developments," Air \& Waste Management Association 82nd Amual Meeting, Anaheim, CA, June 1989.

037 Pasek, R.J. and G.P. Lindner, "Toxic Emission Sampling at the Commerce Refuse to Energy Facility," Air \& Waste Managewnt Assosiating 82nd Annual Meeting, Anaheim, CA, June 1989.

041 Visalli, J.R., "A Comparison of Dioxin, Furan, Corbiging Gas Data from Test Programs at Three MSW Incinerators," J. Air Fal. 1 siticn Control Association, December 1987, pp. 1451-1463.

042 Yasuda, K., M. Kaneko et al, "Basic Research on the Emission of Polycyclic Aromatic Hydrocarbons Caused by Waste Incineration." J. Air \& Waste Management Association, December 1989, pp. 1557-1561. 
043 Denison, R.A., "The Hazards of Municipal Incinerator Ash and Fundamental Objectives of Ash Management," Resource Recovery of Municipal Solid Wastes, AIChE.Symposium Series, vol 34, no. 265. P.J. Knox, ed, AIChE, 1988. pp. $148-153$.

068 Tuttle, K.L., "Combustion Generated Particulate Emissions," Proceedings of ASME National Waste Processing Conference, Denver, CO, June 1986, pp. $1-8$.

069 Hahn, J.L., "Innovative Technology for the Control of Air Pollution at Waste-to-Energy Plants," Proceedings of ASME National Waste Processing Conference, Denver, CO, June 1986, Pp. 9-16.

075 Engdahl, R.B., "Energy Recovery from Raw versus Refined Municipal Wastes," Proceedings of ASME National Waste Processing Conference, Denver, CO, June 1986, pp. 105-112.

077 Hurst, B.E. and C.M. White, "Thermal DeNOx: A Commercial Selective Noncatalytic NOx Reduction Process for Waste-to-Energy Applications," Proceedings of ASME National Waste Processing Conference, Denver, CD, June 1986, pp. 119-127.

085 Stelian, J. and H.L. Greene, "Operating Experience and Performance of Two Wet Ash Handling Systems Used in Mass Burning Solid Waste Facilities," Proceedings of ASME National Waste Processing Conference, Denver, CO, June 1986, pp. 275-282.

086 Frounfelker, R., "Heat Recovery Incineration for the City and Borough of Sitka, Alaska," Proceedings of ASME National Waste Processing Conference, Denver, CO, June 1986, pp. 283-297.

088 Wheless, E. and M. Selna, "Commerce Refuse-to-Energy Facility, an Alternative to Landfilling," Proceedings of ASME National Waste Processing Conference, Denver, CO, June 1986, pp. 317-323.

089 Brickner, R.H. and W.D. Kean, "Power Generation Alternatives - Small Scale Waste-to-Energy Systems," Proceedings of ASME National Waste Processing Conference, Denver, CO, June 1986, Pp. 325-340.

120 Vansant, C., "WTE Equipment: Big Gains in a Short Time," Solid Waste \& Power, June 1991, Pp. 12-16.

137 Frame, G.B., "A Comparison of Air Pollution Control Systems for Municipal Solid Waste Incinerators," J. Air Pollution Control Assoc. vol 39, no. 8, August 1988, pp. 1081-1087.

159 Hasselrif, F., "Optimization of Combustion Conditions to Minimize Dioxin Emissions," Waste Management \& Research 5, 1987, pp. 311-326.

197 Denison, R.A., "Health and Environmental Hazards of Municipal Solid Waste Incinerator Ash," Resource Recovery, April 1989, pp. 14-17. 
217 Repa, E.W. and J.V.I. Kiser, "Disposing Ash." Waste

Alternatives/Landfill of the $90 \mathrm{~s}$, vol. 1, no. 3, published by National Solid Wastes Management Association, December 1988, pp. 74-79.

218 Kapner, M. and S. Schwarz, "A Guide to Air Pollution Control Equipment," Waste Altermatives/Waste-to-Energy, vol. 1, no. 2., published by National Solid Wastes Management Association, September 1988, pp. 38-43.

223 McInnes, R.G., "Spray Dryers and Fabric Filters: State of the Art," Solid Waste \& Power, April 1990, Pp. 24-30.

228 Minott, D.H., "Choosing Between Resource Recovery Facilities and Landfills," Solid Waste \& Power, April 1989, pp. 18-24.

235 "Incineration Provides a Variety of Options," Solid Waste \& Power, February 1988, pp. 12-19.

255 Reason, J., "Next Step for Waste-to-Energy: Better Availability, Efficiency," Power, July 1986, pp. 17-24.

271 Robinson, W.D., ed., The Solid Waste Handbook. A Practical Guide, John Wiley \& Sons, Inc., 1986.

273 Hershkowitz, A. and E. Salerni, Garbage Management in Japan: Leading the Way, INFORM, Inc., New York, NY, 1987.

275 Hickman, H.L., Jr., W. D. Turner et al, Thermal Conversion Systems for Municipal Solid Waste, Noyes Data Corp., Park Ridge, NJ, 1984.

277 Scott, P.J. and W.R.H. Orchard, "A Review of Mass Burning Incineration in Western Europe," Proceedings: Energy Recovery Through Waste Combustion, Elsevier Science, 1988.

282 Cassitto, L,G., "Appropriate Choice of Large Scale Energy Recovery Systems from Municipal and Industrial Wastes," Proceedings: Energy Recovery Through Waste Combustion, Elsevier Science, 1988.

298 U.S. Environmental Protection Agency, Municipal Waste Combustion Study Report to Congress, EPA/530-SW-87-021a, June 1987.

303 U.S. Environmental Protection Agency, Locating and Estimating Air Toxics Emissions from Municipal Waste Combustors, EPA-450/2-89-006, April 1989.

305 Owens, W.L. and W.D. Conn, "Communicating Risks Associated with Existing and New Municipal Solid Waste Facilities," Proc., First U.S. Conference on Municipal Solid Waste Management: Solutions for the 90s, Vol I. Washington, DC, U.S. EPA Office of Solid Waste, June 1990. 
321 Goodwin, R.W., "Utilizatioñ Applications of Resource Recovery Residue," Proc., First U.S. Conference on Municipal Solid Waste Management:

Solutions for the $90 \mathrm{~s}$, Vol I. Washington, DC, U.S. EPA Office of Solid Waste, June 1990.

348 Gershman, Brickner \& Bratton, Inc., Small-Scale Municipal Solid Waste Energy Recovery Systems, Van Nostrand Reinhold, 1986.

351 Bendersky, D., D.R. Keyes et al, Resource Recovery Processing Equipment, Pollution Technology Review No. 93, Noyes Data Corp., Park Ridge, NJ, 1982.

352 HDR Engineering, Inc., Detailed Technology Assessment Report for Konmouth County Waste Recovery System, June 1988.

358 Kosson, D.S., H. van der Sloot et al, "A Comparison of Solidification/Stabilization Processes for Treatment of Municipal Waste Combustor Residues, Part II - Leaching Properties," Municipal Waste Combustion Conference sponsored by U.S. EPA and AWMA, Tampa, FL, April 1991.

359 Holmes, T., D. Kosson and C. Wiles, "A Comparison of Five Solidification/Stabilization Processes for Treatment of Municipal Waste Combustion Residues, Part I - Physical Testing," Municipal Waste Combustion Conference sponsored by U.S. EPA and AWMA, Tampa, FL, April 1991.

360 Andrews, J.C., Jr., "Incinerator Ash Disposal in the Tampa Bay Region," Municipal Waste Combustion Conference sponsored by U.S. EPA and AWMA, Tampa, FL, April 1991.

361 Goodwin, R.W., "Engineering Evaluation of Resource Recovery Residue Utilization Modes," Municipal Waste Combustion Conference sponsored by U.S. EPA and AWMA, Tampa, FL. April 1991.

367 Donnelly, J.R., - Overview of Air Pollution Controls for Municipal Waste Combustors," Municipal Waste Combustion Conference sponsored by U.S. EPA and AWRA, Tampa, FL, April 1991.

370 Brna, T.G., "Toxic Metal Emissions from MWCs and Their Control," Municipal Waste Combustion Conference sponsored by U.S. EPA and AWMA, Tampa, FL, April 1991.

373 Levin, A., D.B. Fratt et al, "Comparative Analysis of Health Risk Assessments for Municipal Waste Combustors," J. Air \& Waste Management Association, January 1991, Pp. 20-31.

387 Bereny1, E. and R. Gould, 1991 Resource Recovery Yearbook, Directory \& Guide, Governmental Advisory Assoclates, Inc., New York, NY, 1991. 
402 Barrett, R.E. et al, Municipal Waste-to-Energy Technology Status, Battelle Memorial Institute Report, August 1989.

435 Minott, D.H., "Fluid-Bed Energy Recovery Facllities: Operating Principles and Environmental Performance," Proceedings: International Conference on Municipal Waste Combustion, Hollywood, FL, Minister of Supply and Services, Canada, April 1989, Pp. 5A-1/5A-25.

439 Binder, J.J. and D.H. Minott, "Siting a Resource Recovery Facility: Community Decision-Making, Risk Education, and Multi-Faceted Compensation," Proc: International Conference on Municipal Waste Combustion, Hollywood, FL, Minister of Supply and Services, Canada, Apr11 1989, Pp. 8B-21/8B-47.

441 Murdoch, J.D., "Material Recovery with Incineration, Monmouth County, New Jersey," Proc: International Conference on Municipal Waste Combustion, Hollywood, Fl, Minister of Supply and Services, Canada, April 1989, Pp. 9A-1/9A-15.

471 Rood, M.J., Technological and Economic Evaluation of Municipal Solid Waste Incineration, Commissioned by OTI, UI. of Illinois Center for Solid Waste Management and Research, Chicago, II, September 1988.

472 Hegberg, B.A., W.H. Hallenbeck and G.R. Brenniman, Municipal Solid Waste Incineration with Energy Recovery, OTT, U. of Illinois Center for Solid Waste Management and Research, Chicago, Il, March 1990.

484 Richards, D. et al, Waste-to-Energy Commercial Facilities Profiles: Technical, Operational and Economic Perspectives, Noyes Data Corp., 1990.

492 Shaub, W.M., "Incineration - Some Environmental Perspectives," Emissions from Combustion Processes: Origin, Measurement, Control. R. Clement, R. Kagel, eds., Lewis Publishers, Inc., 1990.

514 Takacs, L. and G.I. Moilanen, "Simultaneous Control of PCDD/PCDF, HCI and NOx Emissions from MSW Incinerators with Ammonia Injection, " J. Alr \& Waste Management Association, May 1991, pp. 716-722.

520 Kidder, Peabody, \& Co., Inc., Industry Report: Waste-to-Energy Industry, November 1989.

530 Harlow, G.L. et al, "Ash Vitrification - A Technology Ready for Transfer," Proceedings of ASME National Waste Processing Conference, Long Beach, CA, June 1990, pp. 143-150.

532 Nakazato, K., "Ash From MSW Incinerator," Proceedings of ASME National Waste Processing Conference, Long Beach, CA, June 1990, PP. 163-169. 
533 Davis, R.J., T.R. Kiska and S.H. Felix, "A Comparative Evaluation of High-Temperature Pulse-Jet Baghouse Filter Fabrics," Proceedings of ASME National Waste Processing Conference, Long Beach, CA, June 1990, Pp. $171-178$.

534 Hands, I.M. and W.G. Schuetzenduebel, "Reducing Oxides of Nitrogen Emissions from Waste-to-Energy Facilities with Operational Controls," Proceedings of ASME National Waste Processing Conference, Long Beach, CA, June 1990, Pp. 179-184.

535 Penterson, C.A. et al, "Natural Gas Reburning Technology for NOx Reduction from MSW Combustion Systems," Proceedings of ASME National Waste Processing Conference, Long Beach, CA, June 1990, PP. 185-191.

537 Hahn, J.I. and D.S. Sofaer, "A Comparison of Health Risk Assessments for Three Ogden Martin Systems, Inc. Resource Recovery Facilities Using Estimated (Permitted) and Actual Emission Levels," Proceedings of ASME National Waste Processing Conference, Long Beach, CA, June 1990, pp. 255-272.

540 Worster, E.S. et al, "The Greater Bridgeport Regional Resource Recovery Project: A Waste-to-Energy Reincarnation," Proceedings-of ASME National Waste Processing Conference, Long Beach, CA, June 1990, pp. 345-351.

541 Butler, A.J., "Skagit County Resource Recovery Facility Design of a 178 TPD Waste-to-Energy Plant," Proceedings of ASME National Waste Processing Conference, Long Beach, CA, June 1990, Pf. 353-362.

545 Beachler, D.S. and N.M. Hirko, "Air Emission Test Results from the Dutchess County Resource Recovery Facility, " Proceedings of ASME National Waste Processing Conference, Long Beach, CA, June 1990, pp. 405-416.

546 Davis, W.H. and M.D. Carter, "History of the Southeast Resource Recovery Project." Proceedings of ASME National Waste Processing Conference, Long Beach, CA, June 1990, pp. 439-443.

547 Rankin, S., "Recycling Plastics in Municipal Solid Wastes I: Myths and Realities," J. Resource Management and Technology, October 1989, Pp. $143-148$.

561 U.S. Environmental Protection Agency, Federal Register, 40 CFR Parts 51, 52, and 60. Standards of Performance for New Stational Sources and Final Emission Guidelines; Final Rules. 11 Feb 1991.

574 Brickner, R.H., "Mass Burning Combustion Technologies for Municipal Solid Waste," presented to Resource Recovery Leadership Institute, U.S. Conf of Mayors/NRRA.

578 National Solid Wastes Management Association Institute of Resource Recovery, "Management of Municipal Waste Combustion Ash," 1987. 
583 Walter, D.K., "Energy and Waste: A Status Report," Waste Age, May 1986, 4 p.

591 Ishizuka, M. and S. Katoh, "Current Evaluation and View of Technique of Municipal Waste Incineration," Proceedings: Eighth Japan-United States Govermmental Conference on Solid Waste Management, Honolulu, HI, September 1989.

592 Aoki, H. and S. Koyanagi, "Facilities for Recycling Incineration Residue: Case Study of Sakae Plant," Proceedings: Eighth Japan-United States Governmental Conference on Solid Waste Management, Honolulu, HI, September 1989.

605 Katy Industries, Inc., "Katy Industries, Inc." International Small-Scale Municipal Waste-to-Energy Conference sponsored by Resource Recovery Report and GBB, Washington, DC, Feb-Mar 1985.

608 Honsaker, W.G., "The Westinghouse/0'Connor Combustor Approach to Small Scale Waste-to-Energy Facilities," International Small-Scale Municipal Waste-to-Energy Conference sponsored by Resource Recovery Report and GBB, Washington, DC, Feb-Mar 1985.

611 Consumat Systems, Inc., "Consumat Systems, Inc.," International Small-Scale Municipal Was Recovery Report and GBB, Washington, DC, Feb-Mar 1985.

612 Clear Air Inc., "Clear Air Inc.," International Small-Scale Municipal Waste-to-Energy Conference sponsored by Resource Recovery Report and GBB, Washington, DC, Feb-Mar 1985.

636 Barrett, R.E. et al, "Technology Status Assessment of Municipal Refuse-to-Energy Systems," Proceedings: 1989 Conference on Municipal Solid Waste as a Utility Fuel, EPRI GS-6994, February 1991.

716 Will County, IL, Will County Solid Waste Management Plan, Vol V - Waste to Energy Feasibility Study, January 1991.

723 Office of Technology Assessment, Congress of the U.S., "Facing America's Trash: What Next for Municipal Solid Waste?," Washington, DC, 1988.

797 Pompelia, M., "NOx: How Much of a Concern?," Waste Age, November 1989, $4 \mathrm{p}$.

799 HDR Engineering, Inc., Lake County (IL) Solid Waste Management Plan, Vol III, Appendices Al - A5, prepared for Lake Counsy Joint Action Solid Waste Planning Agency, April 1989.

824 "Treatment and Use: The Future of Ash Management?" Solid Waste \& Power, October 1991, pp. 20-28. 
825 Rogoff, M., "The Ash Debate: States Provide Solutions," Solid Waste \& Power, October 1991, Pp. 12-18.

857 Miller, H., "Dioxins from Combustion," Licentiace Thesis, University of Lund, 1989. As Cited In: Barrett, R.E. et al, Municipal

Waste-to-Energy Technology Status, Battelle Memorial Institute Report, August 1989.

858 Martin, N., Personal communication with Penberthy Electromelt International, Inc., 1991.

859 New York State Department of Environmental Conservation, Phase 1 Resource Recovery Facility Emission Characterization Study - Overview Report, Albany, NY, May 1987. As Cited In: Binder, J.J. and D.H. Minott, "Siting a Resource Recovery Facility: Community Decision-Making, Risk Education, and Multi-Faceted Compensation, "Proc: International Conference on Municipal Waste Combustion, Hollywood, FL, Minister of Supply and Services, Canada, April 1989, Pp. 8B-21/8B-47.

897 Ufthara, A.M. and M. Gough, Managing Ast from Municipal Waste Incinerators - A Report. Center for Ris's Management, Resources for the Future, Washington,. DC, November 1989.

898 Rogoff, M.J., The Ash Debate: States Provide Solutions, Solid Waste \& Power, October 1991, Pp. 12-18.

899 Opinion of the United States Court of Appeals for the Seventh Circuit, Case No. 90-3060, Environmental Defense Fund, Inc., et al versus the City of Chicago, et al. Decided 19 November 1991.

900 MSW Ash Decision Reversed in Chicago, J. Air and Waste Management Association, January 1992.

901 Toxicity Characteristics Revisions; Final Rule. Federal Register, 40 CFR Part 261, Thursday, 29 March 1990.

902 U.S. Patent No. 4,022,630, Portland Cement-Making and Municipal Refuse Conversion (Direct Co-Firing), 10 May 1977.

903 U.S. Patent No. 4,081,285, Portland Cement Manufacture (Indirect Co-Firing), 28 March 1978. 
ATTACHMENT 1.

GRATE MANUFACTURERS - MASS BURN FACILITES

(Derived from 387) 


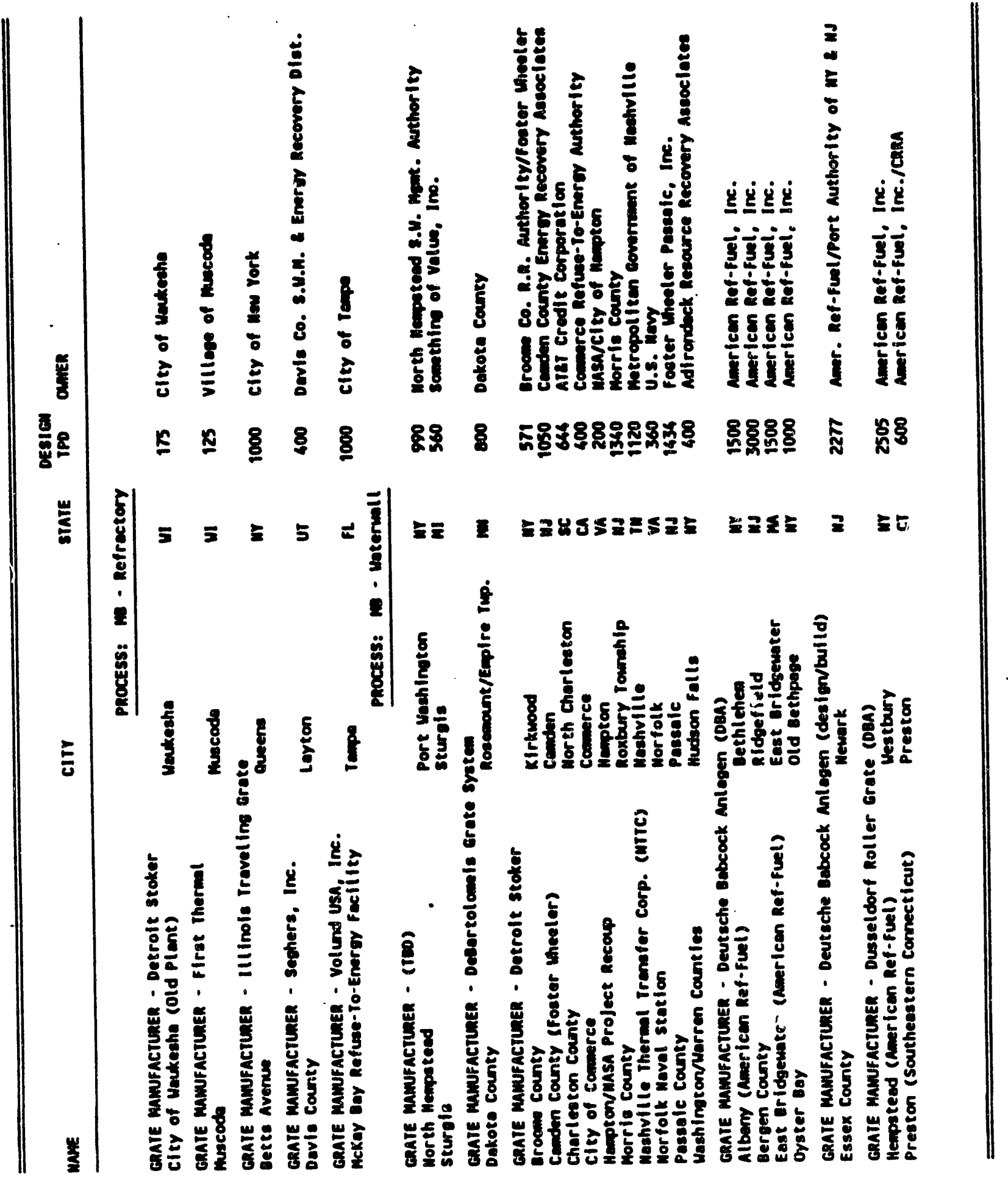




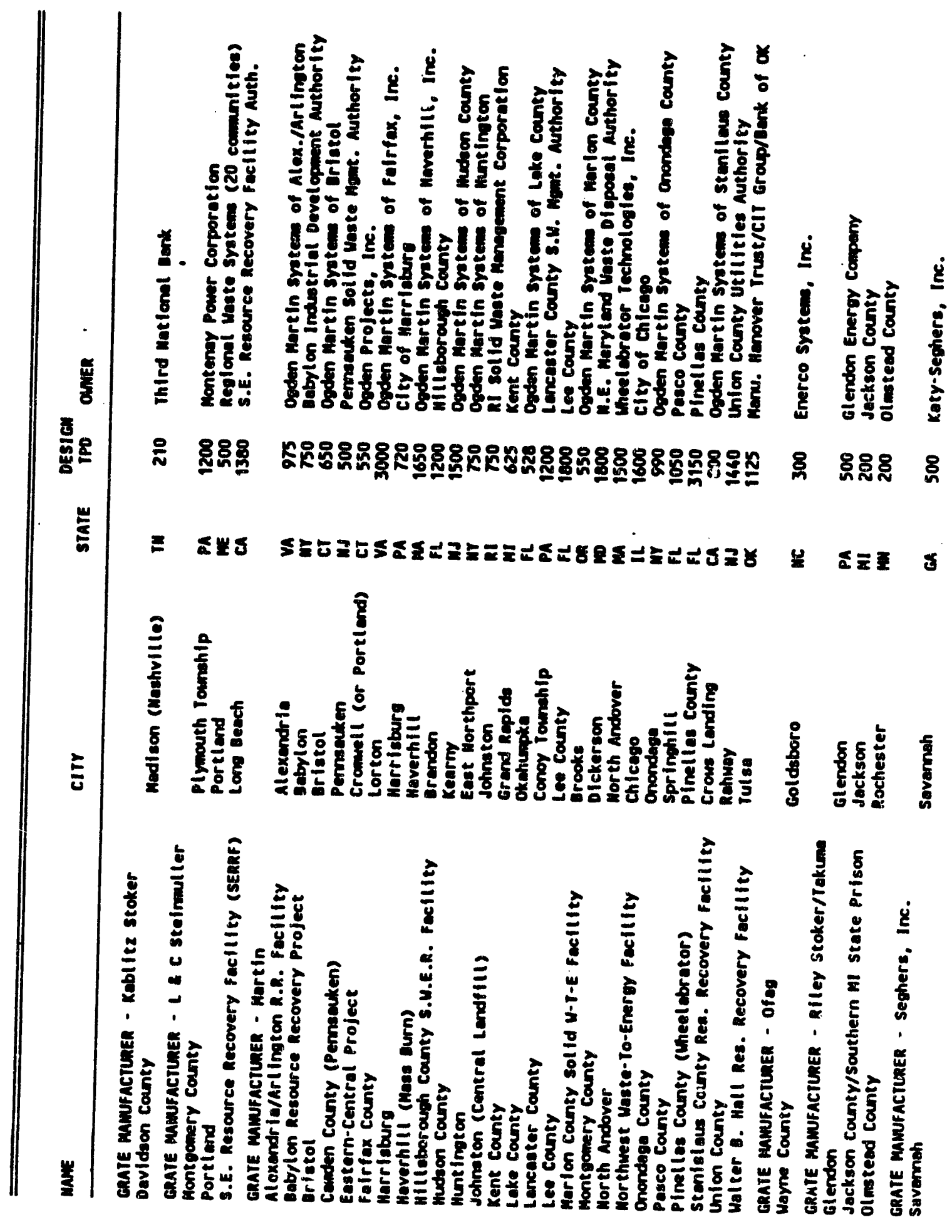




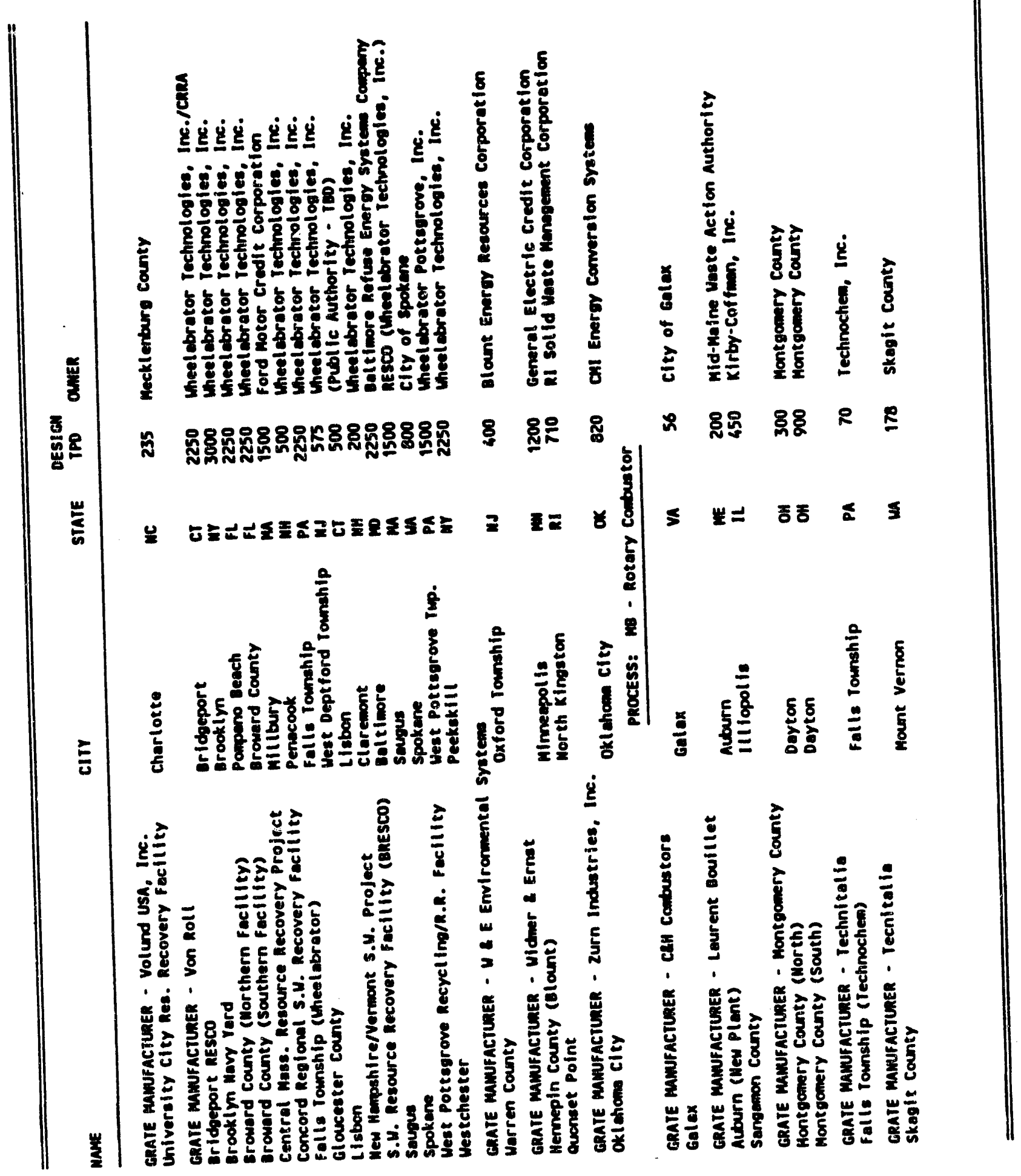




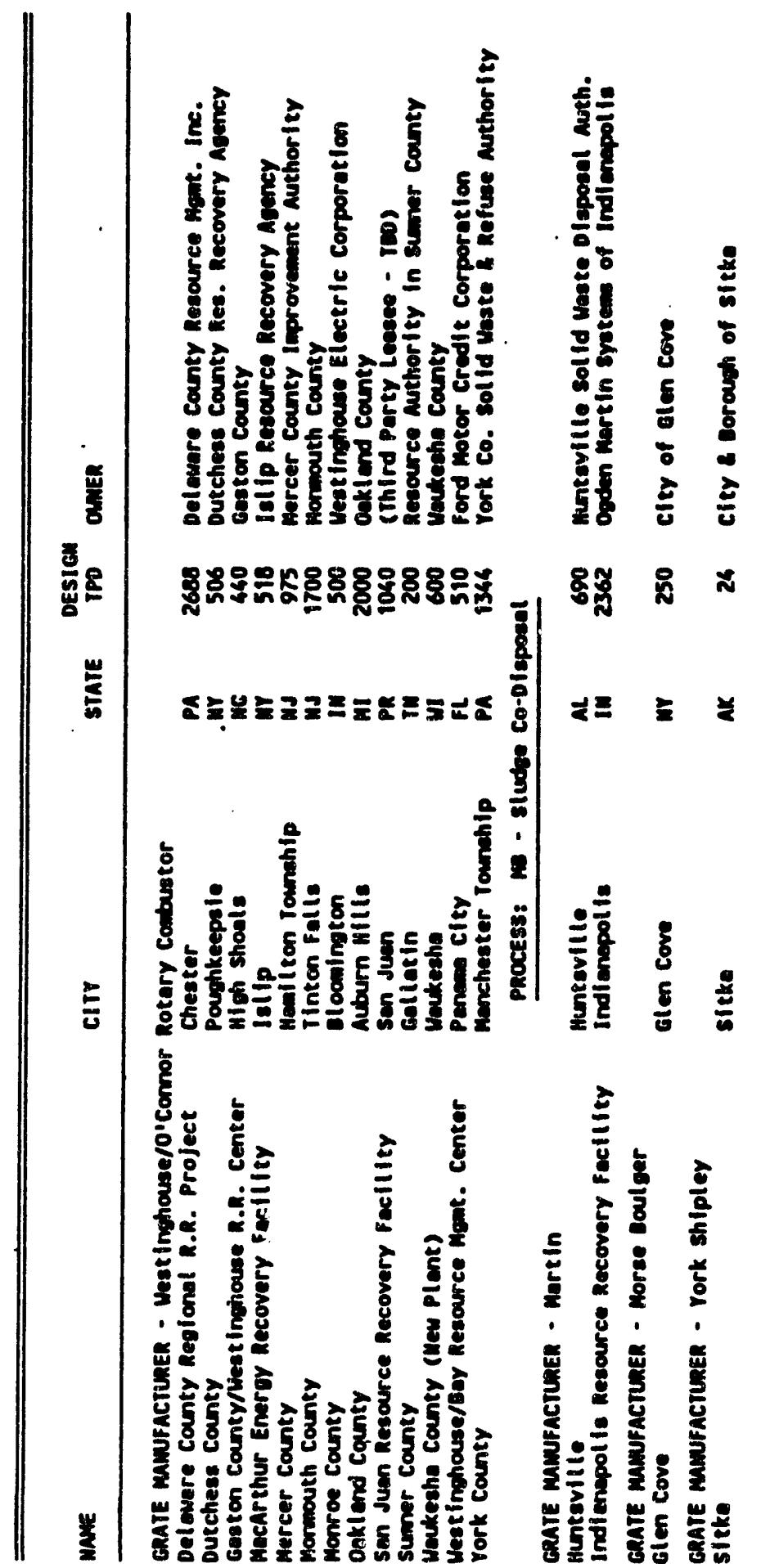


ATTACHMENT 2.

BOILER MANUFACTURERS - MASS BURN FACILITIES

(Derived from 387) 


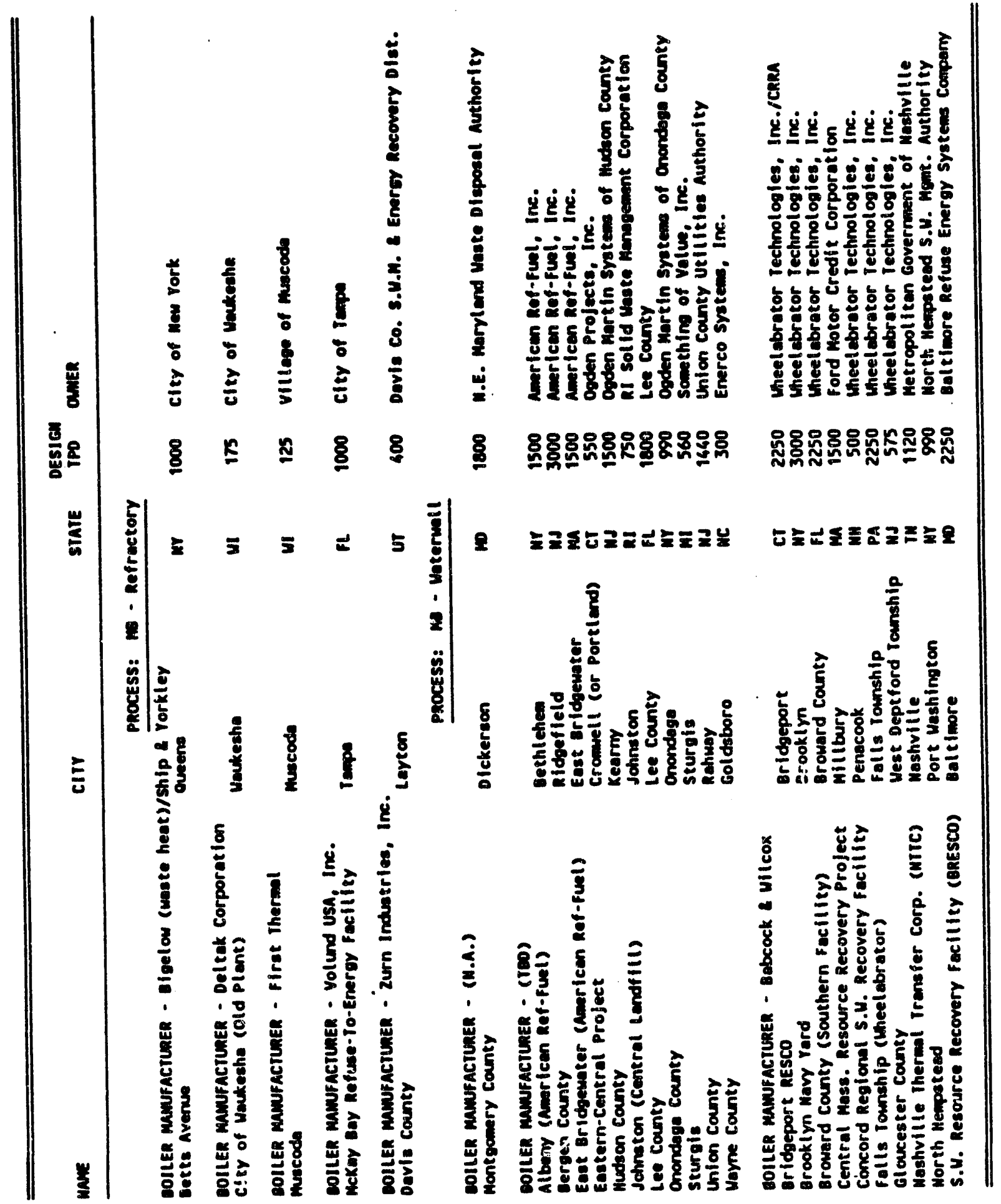




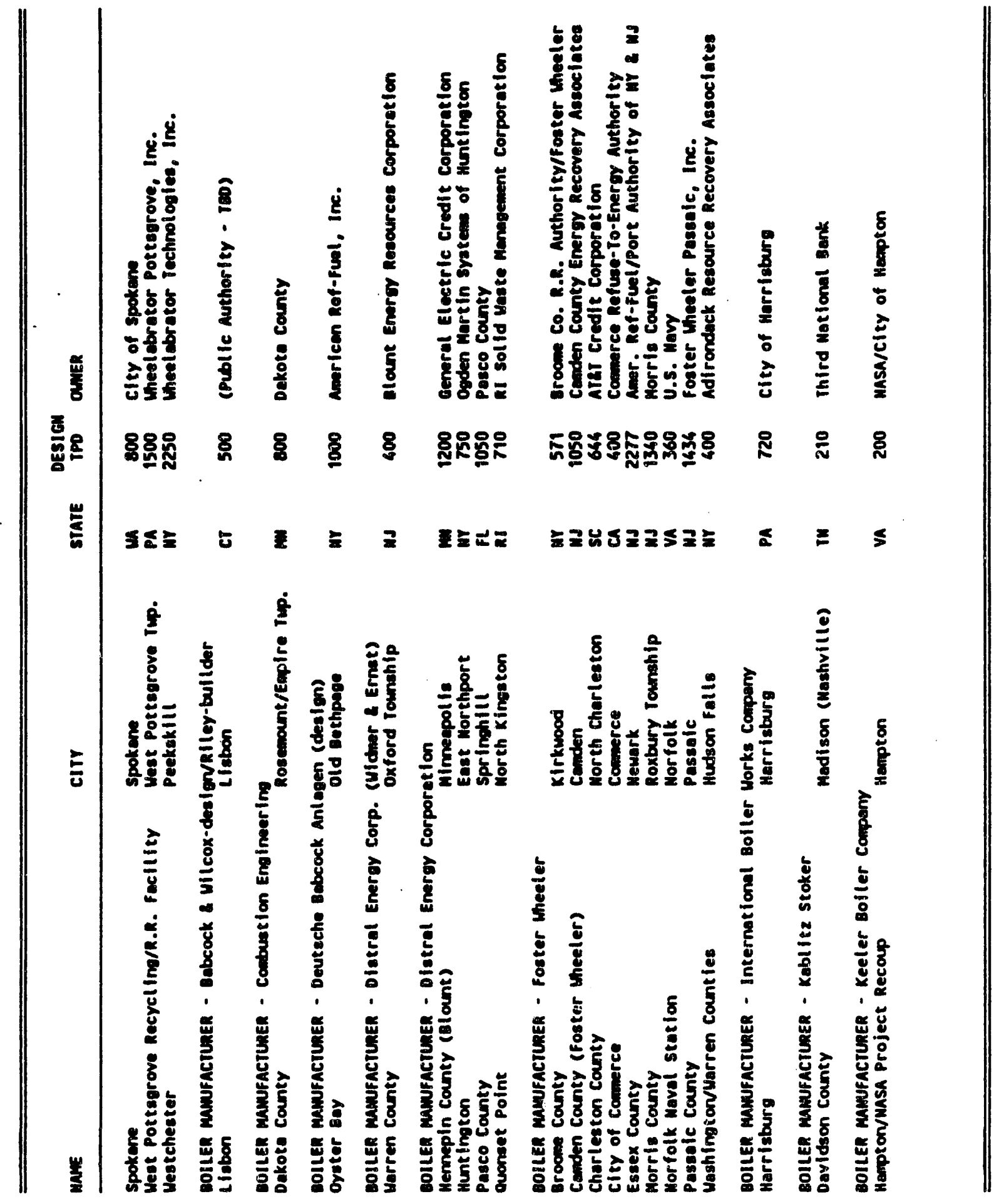




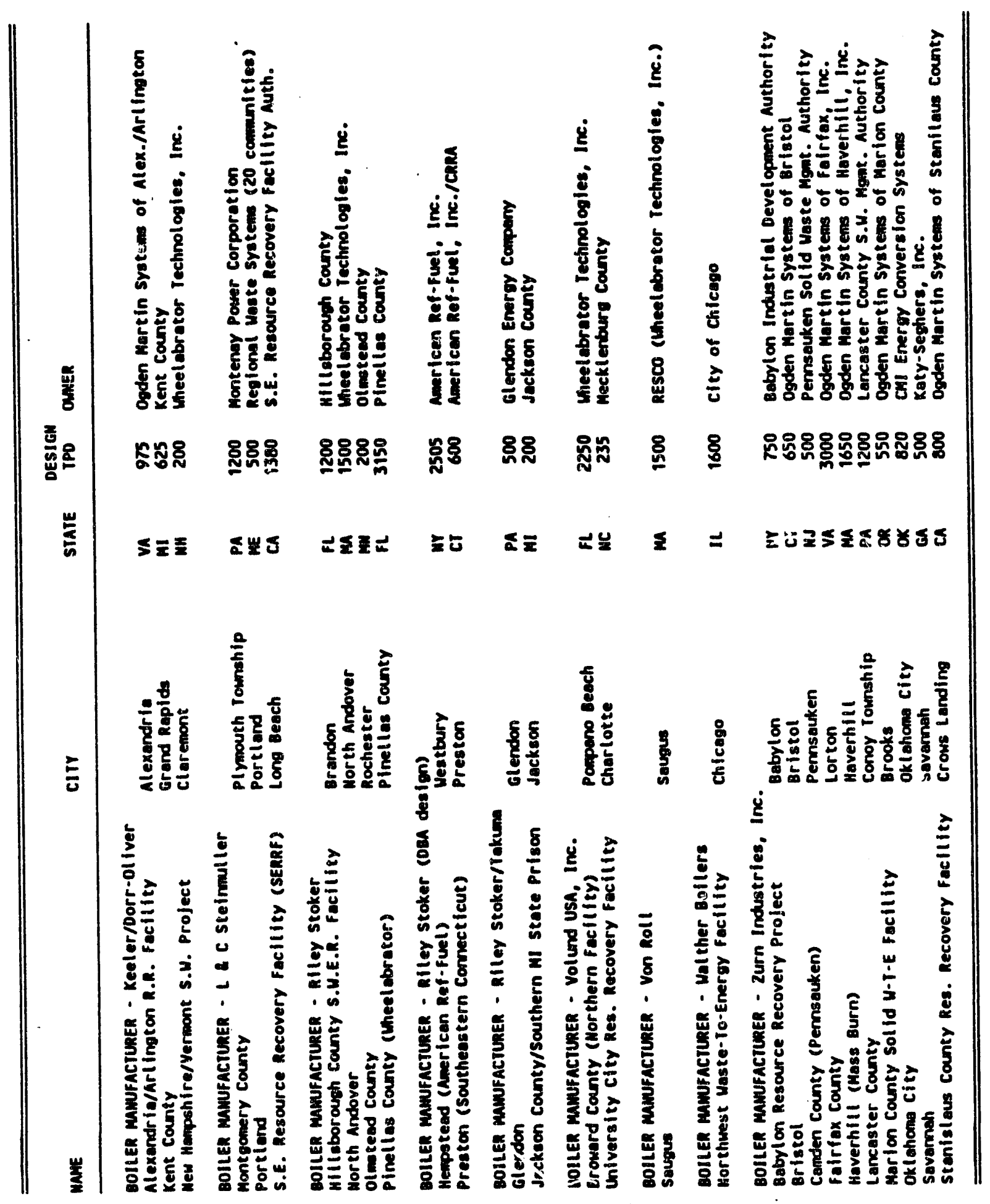




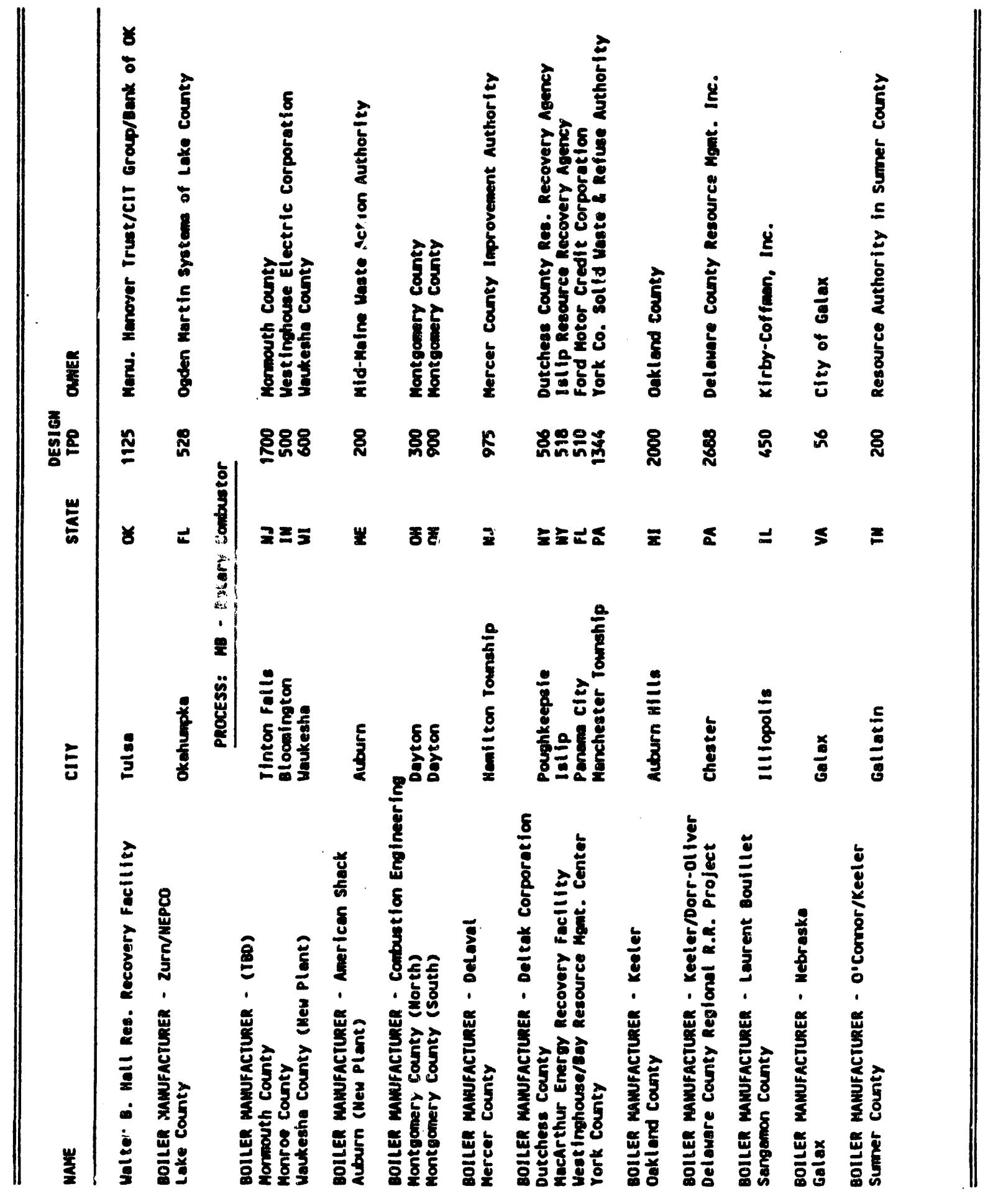




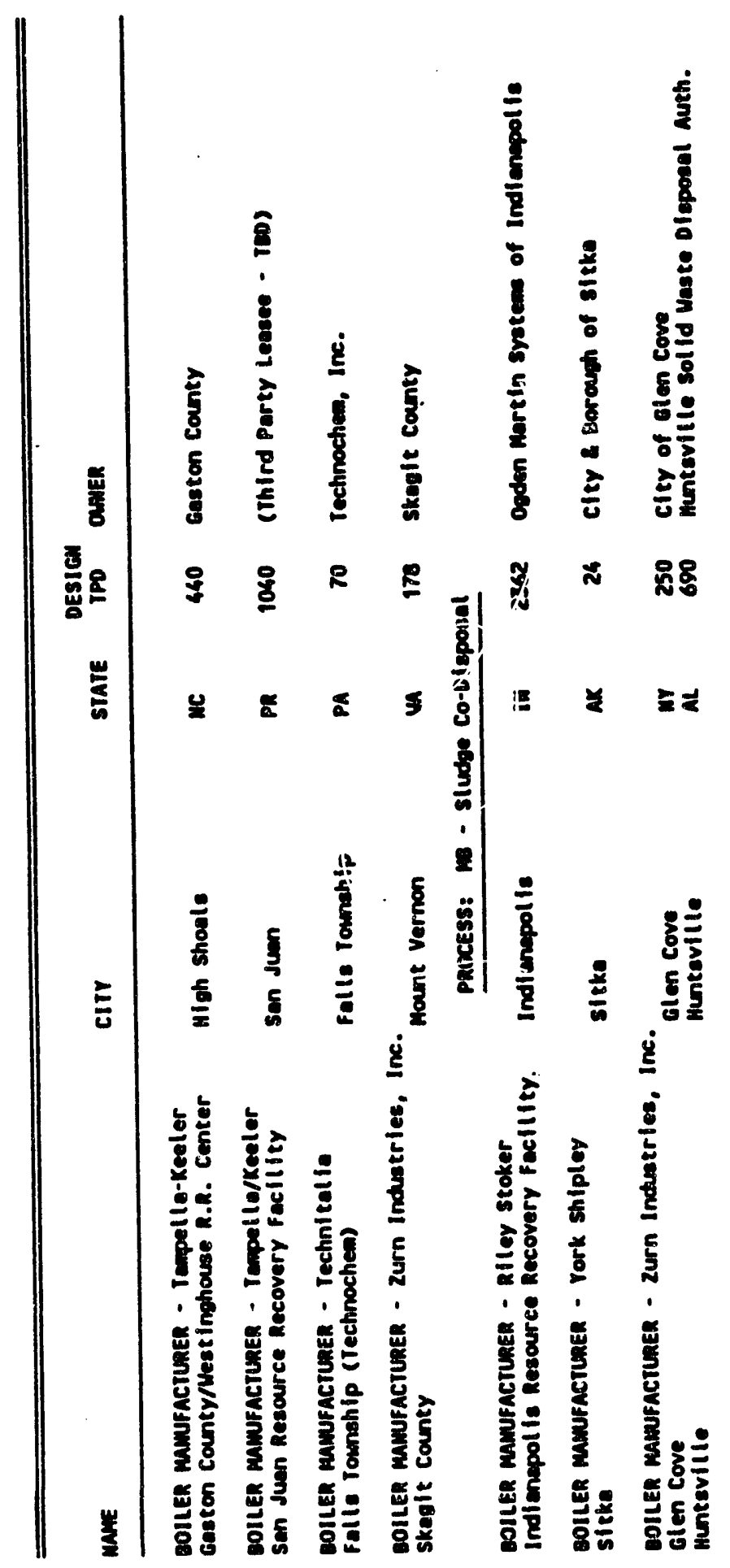


ATTACHMENT 3.

CAPITAL COSTS - FIELD-ERECTED MASS BURN FACILITIES

GROUPED BY APC METHOD

(Derived from 387) 


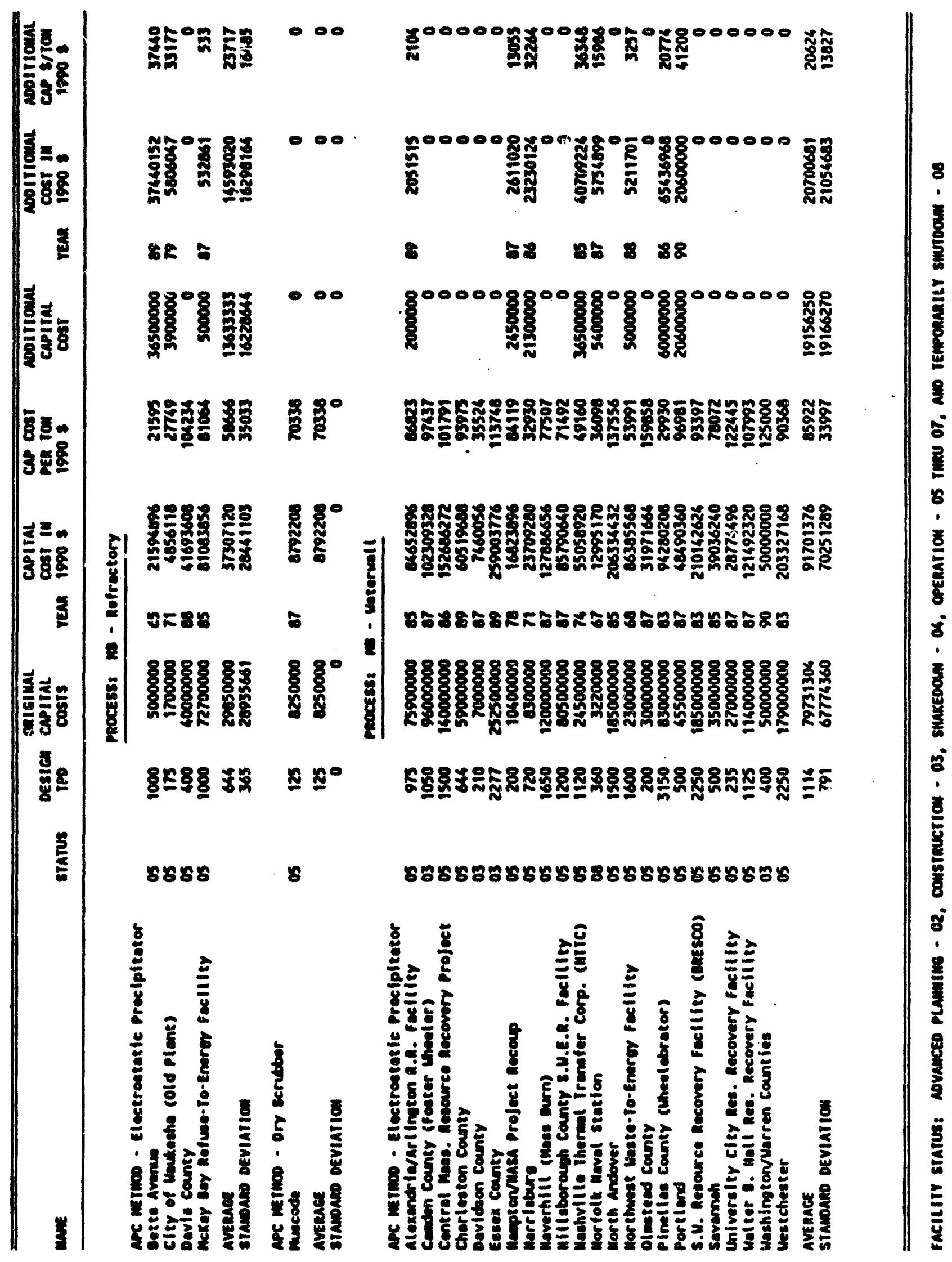




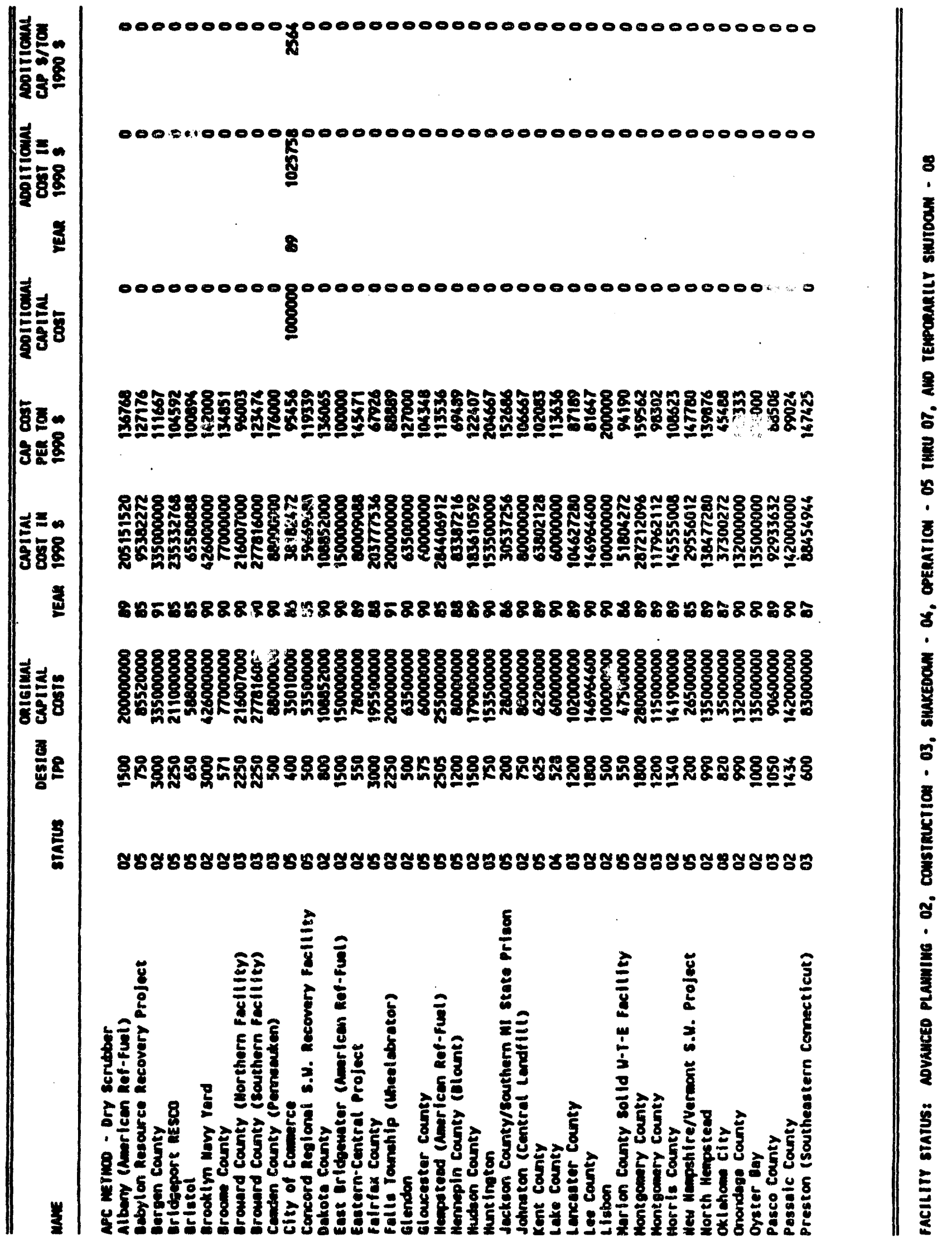




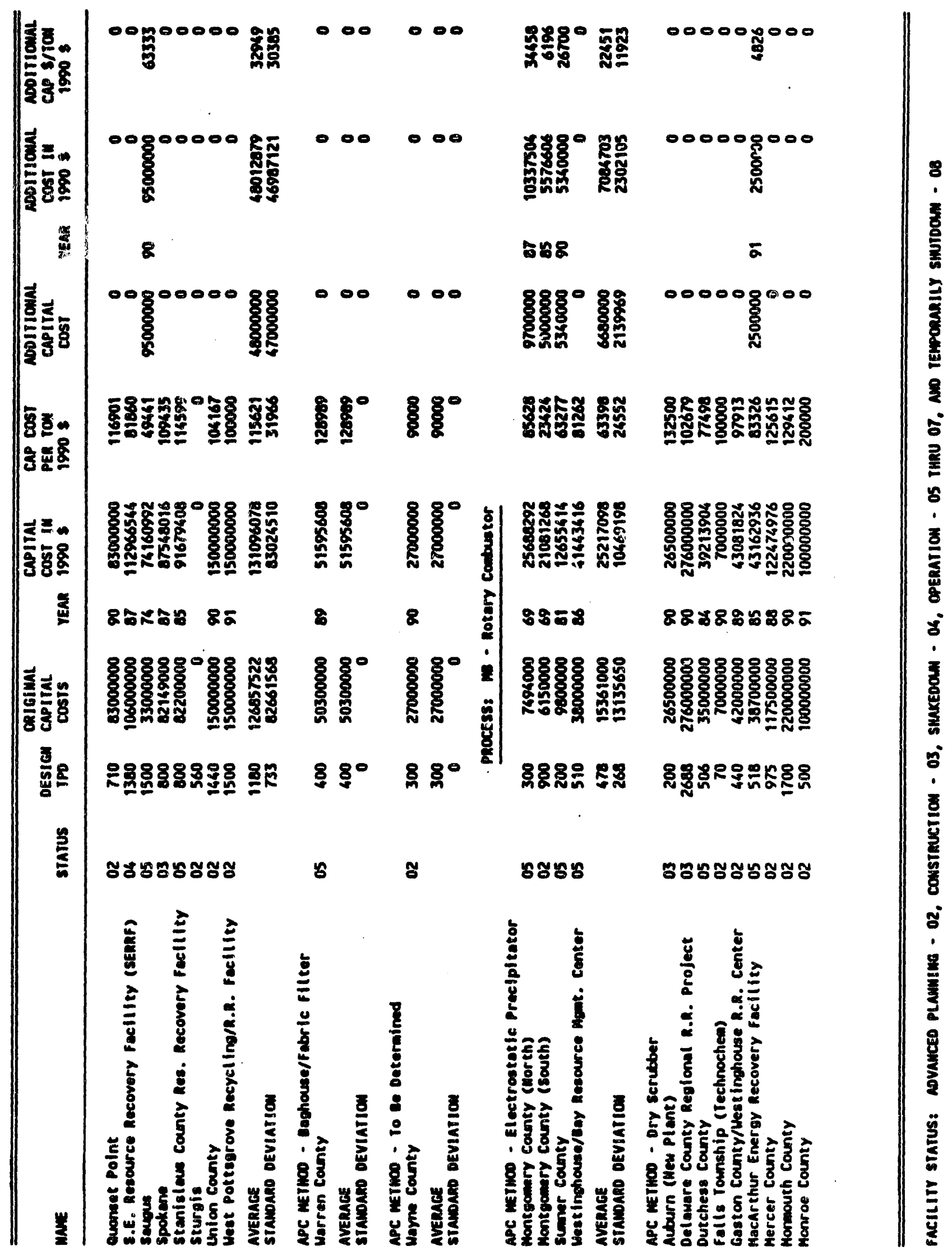




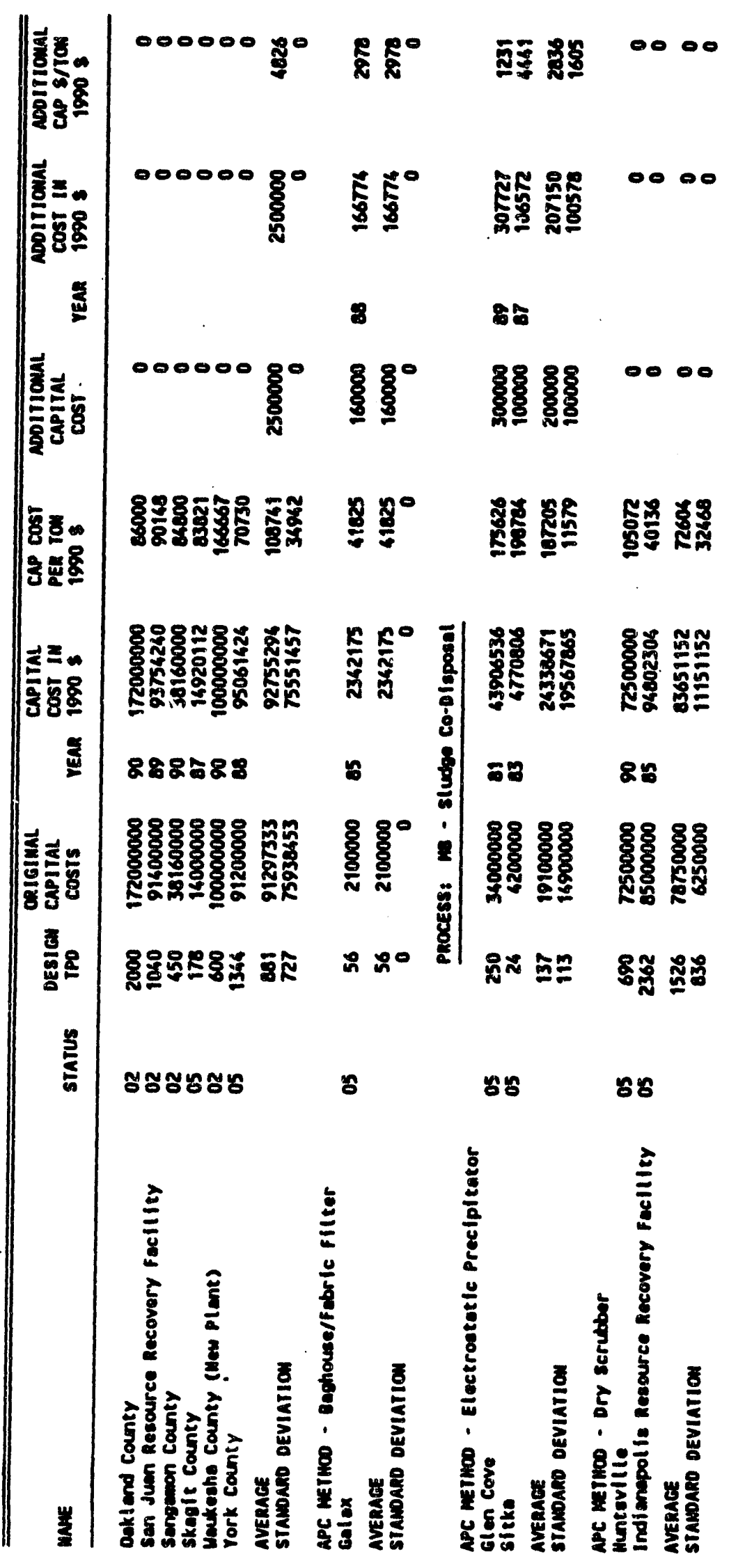

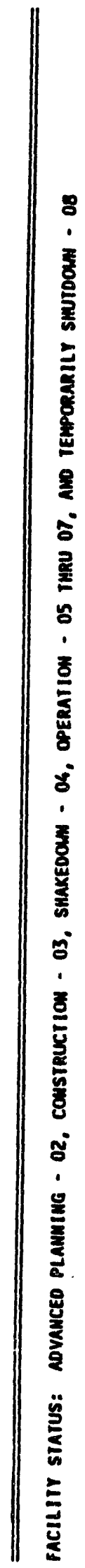




\section{ATTACHMENT 4.}

CAPITAL COSTS - FIELDDERECTED MASS BURN FACILITIES GROUPED BY TYPE OF ENERGY PRODUCTION

(Derived from 387) 


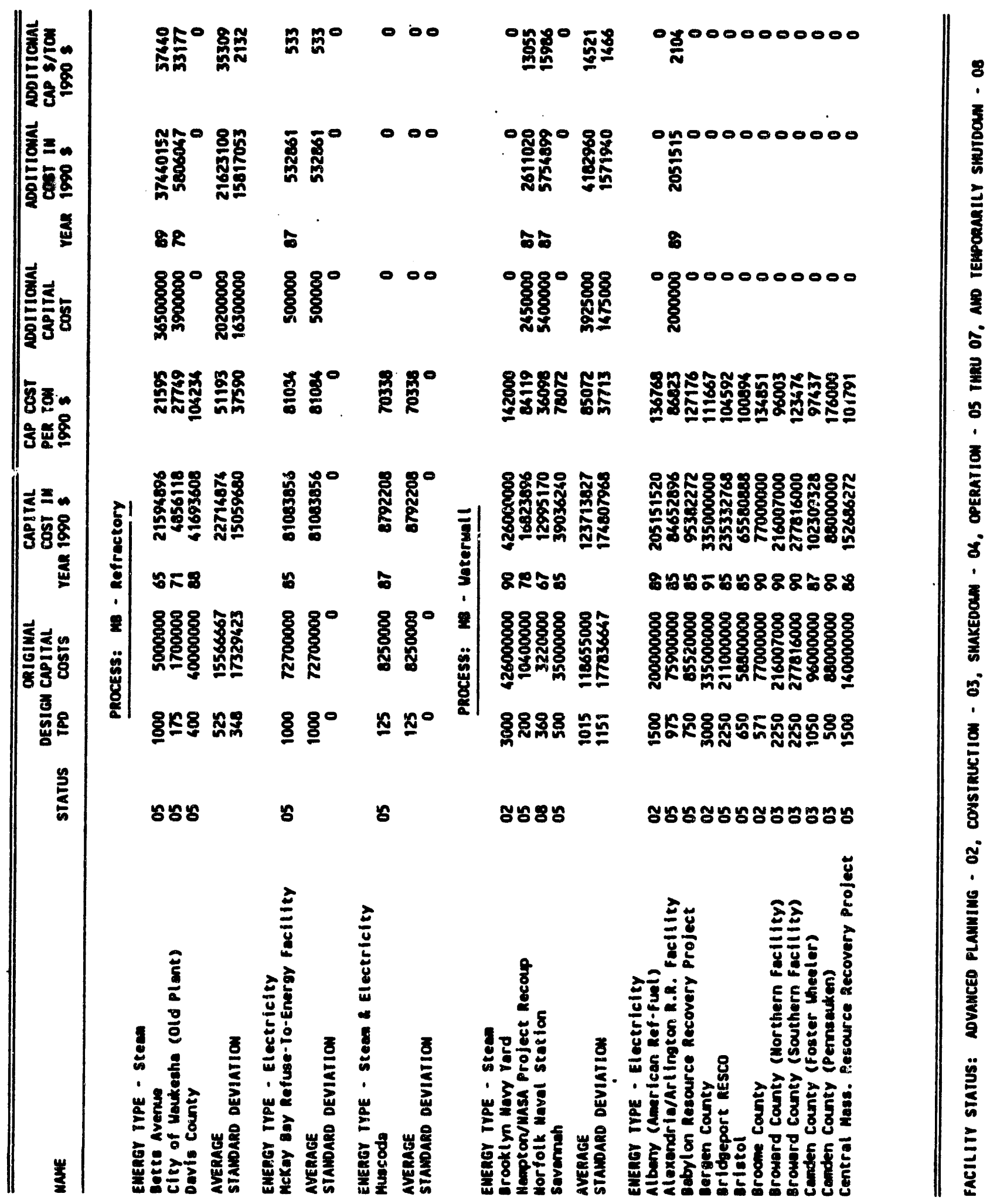




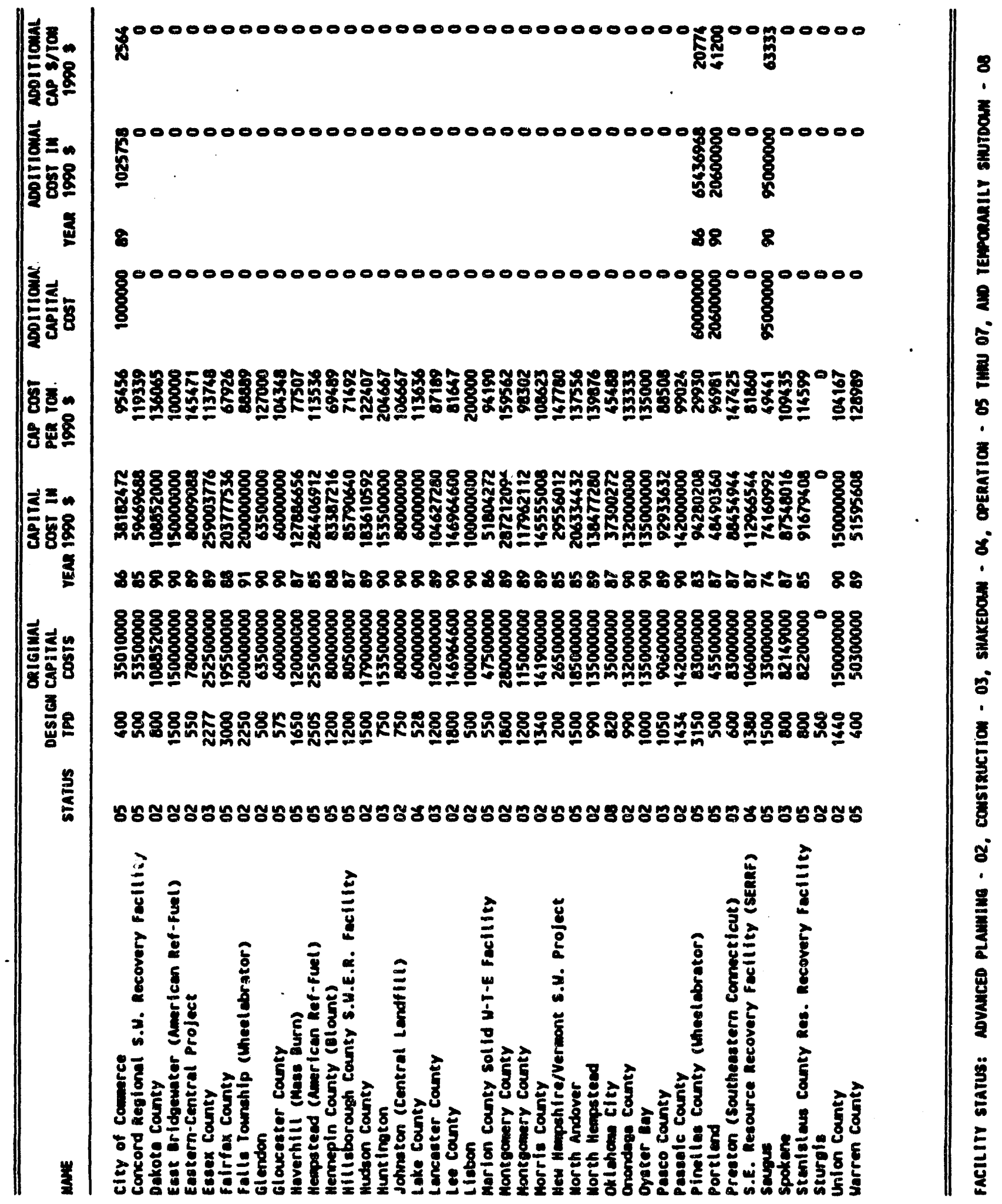




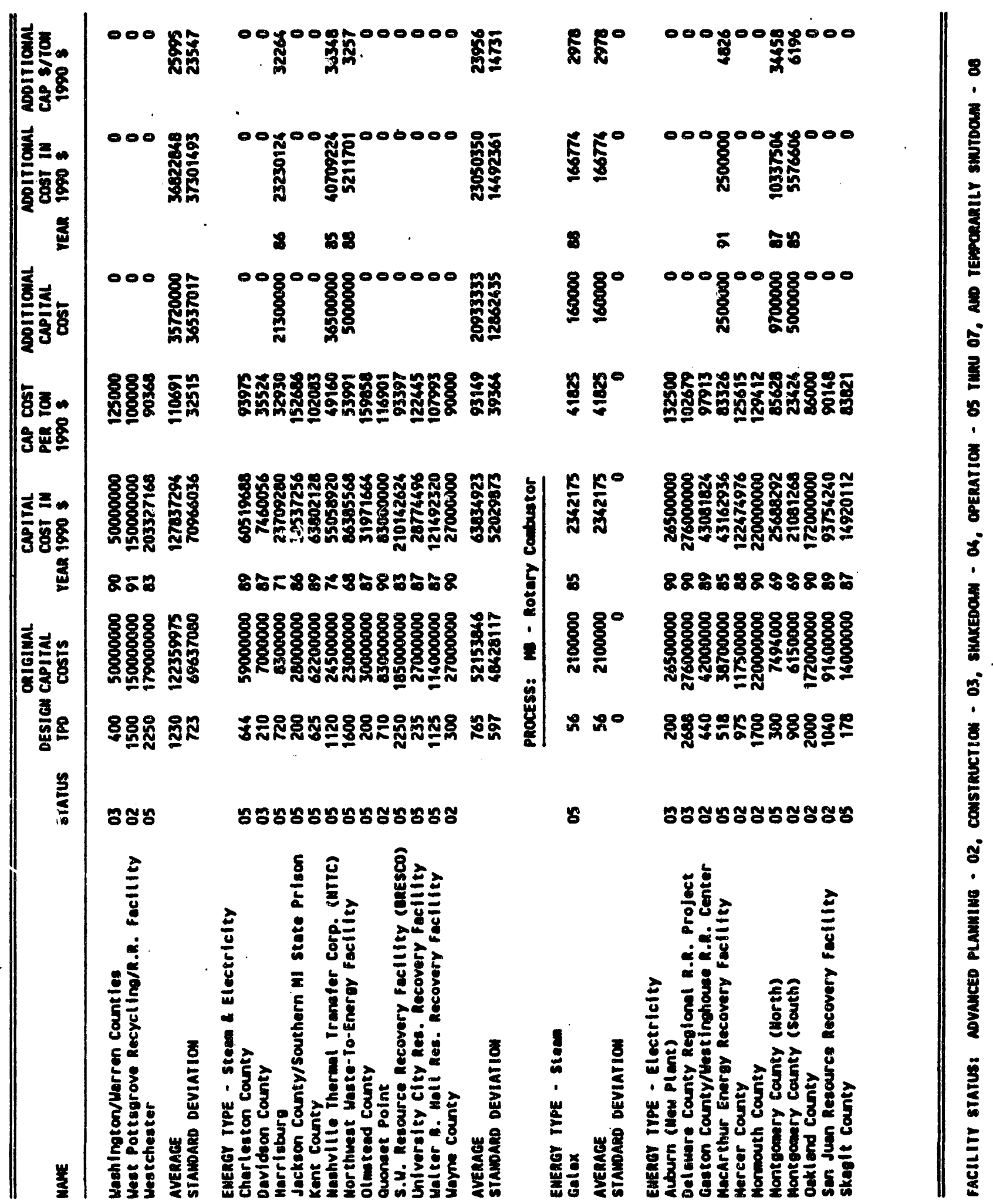




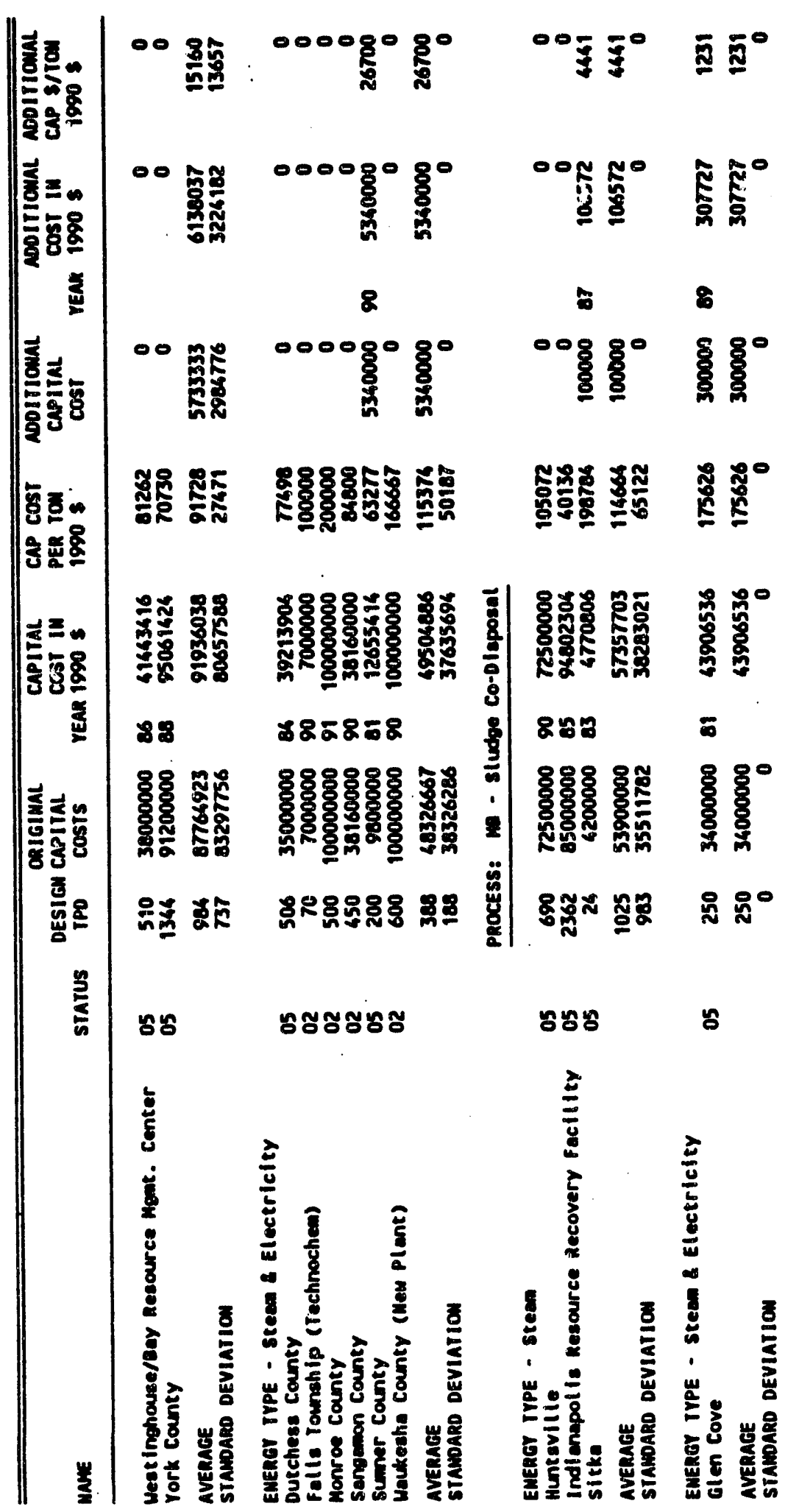

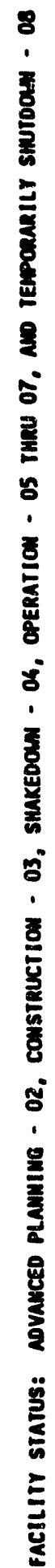


ATTACHMENT 5.

O\&M COSTS - FIELD-ERECTED MASS BURN FACILITIES

(Derived from 387) 


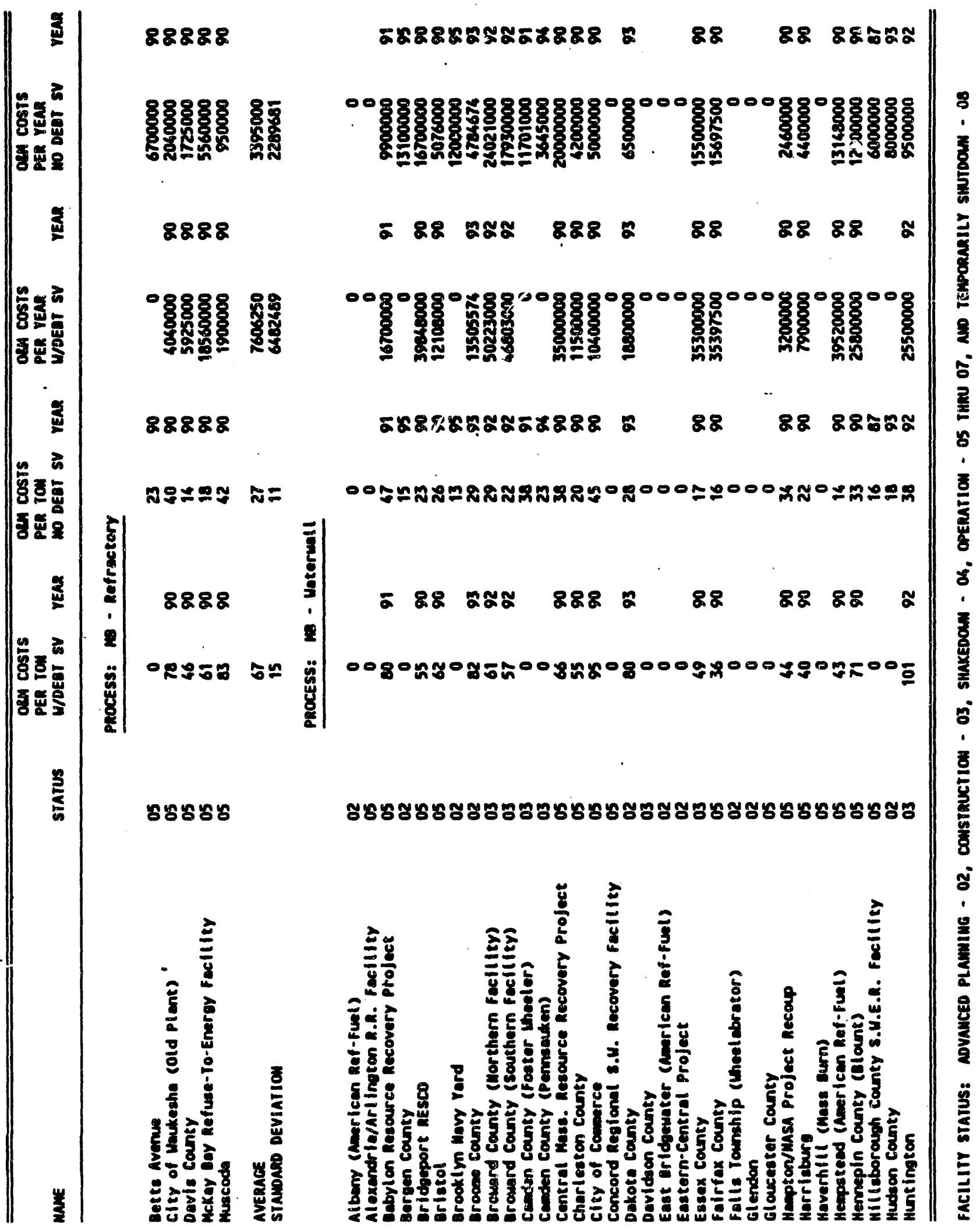




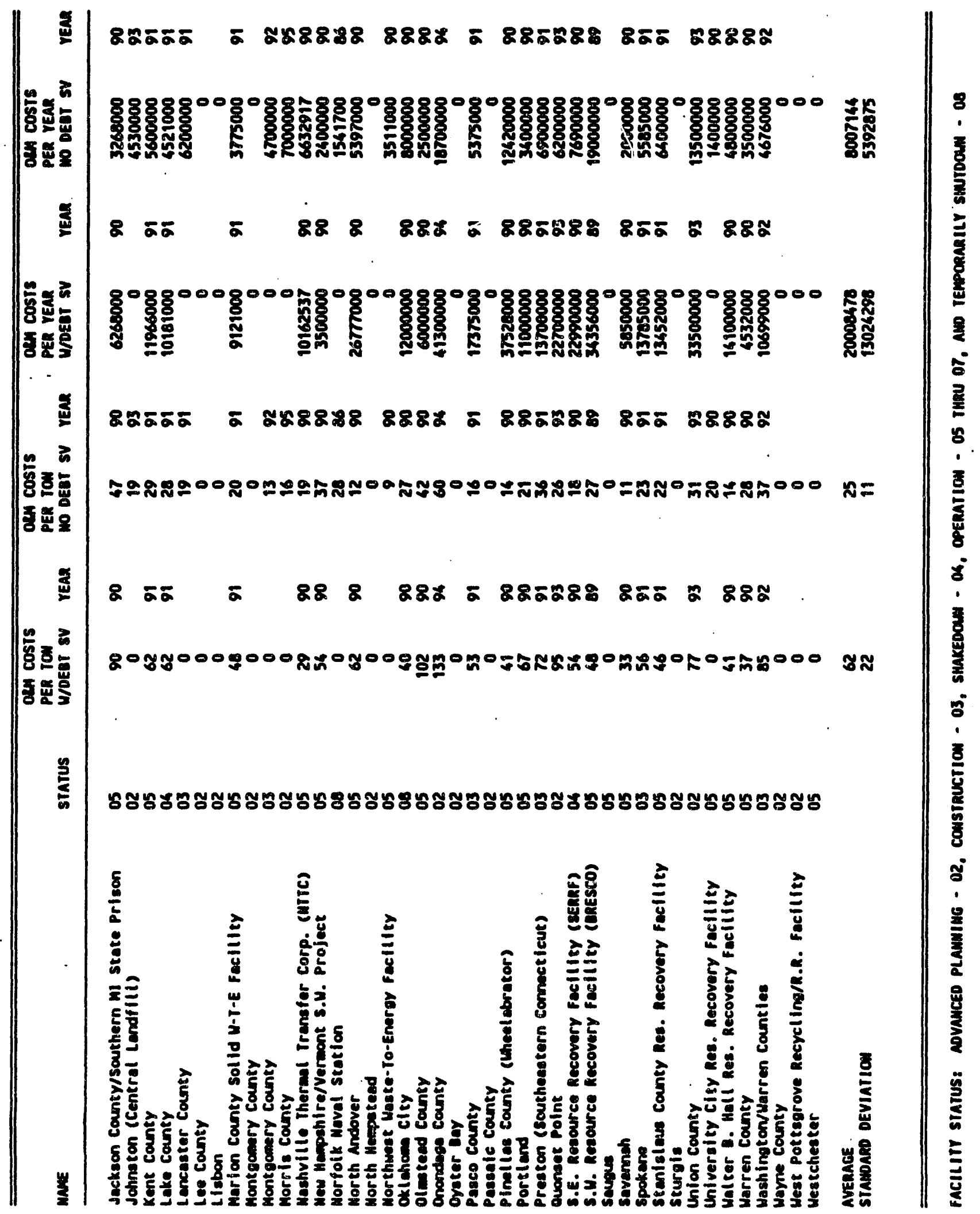




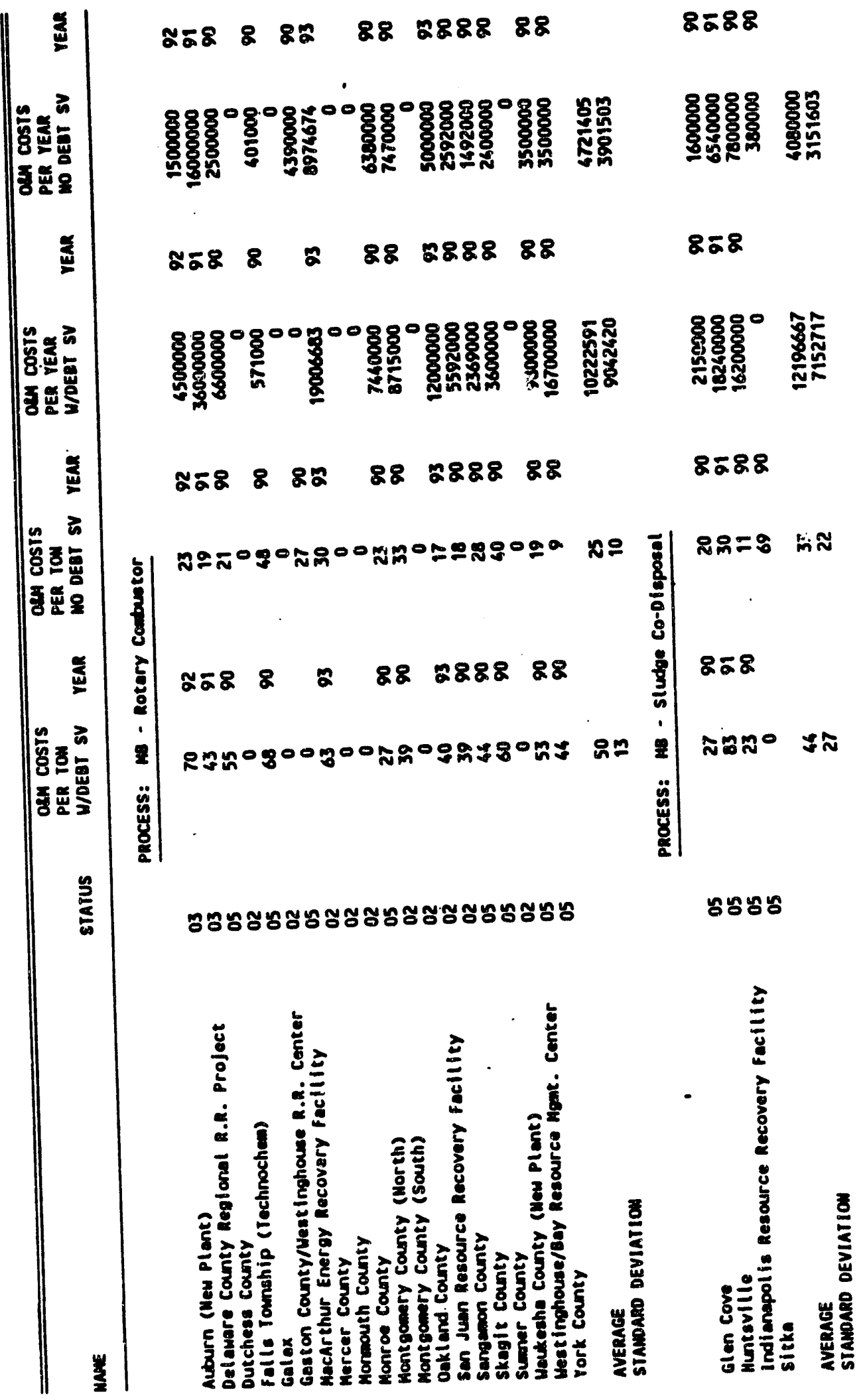

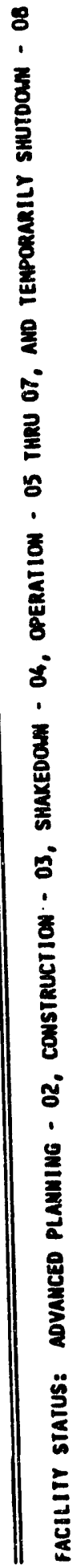




\section{ATTACHMENT 6. \\ STAFFING LEVELS}

FIELD-ERECTED MASS BURN FACILITIES

(Derived from 387) 


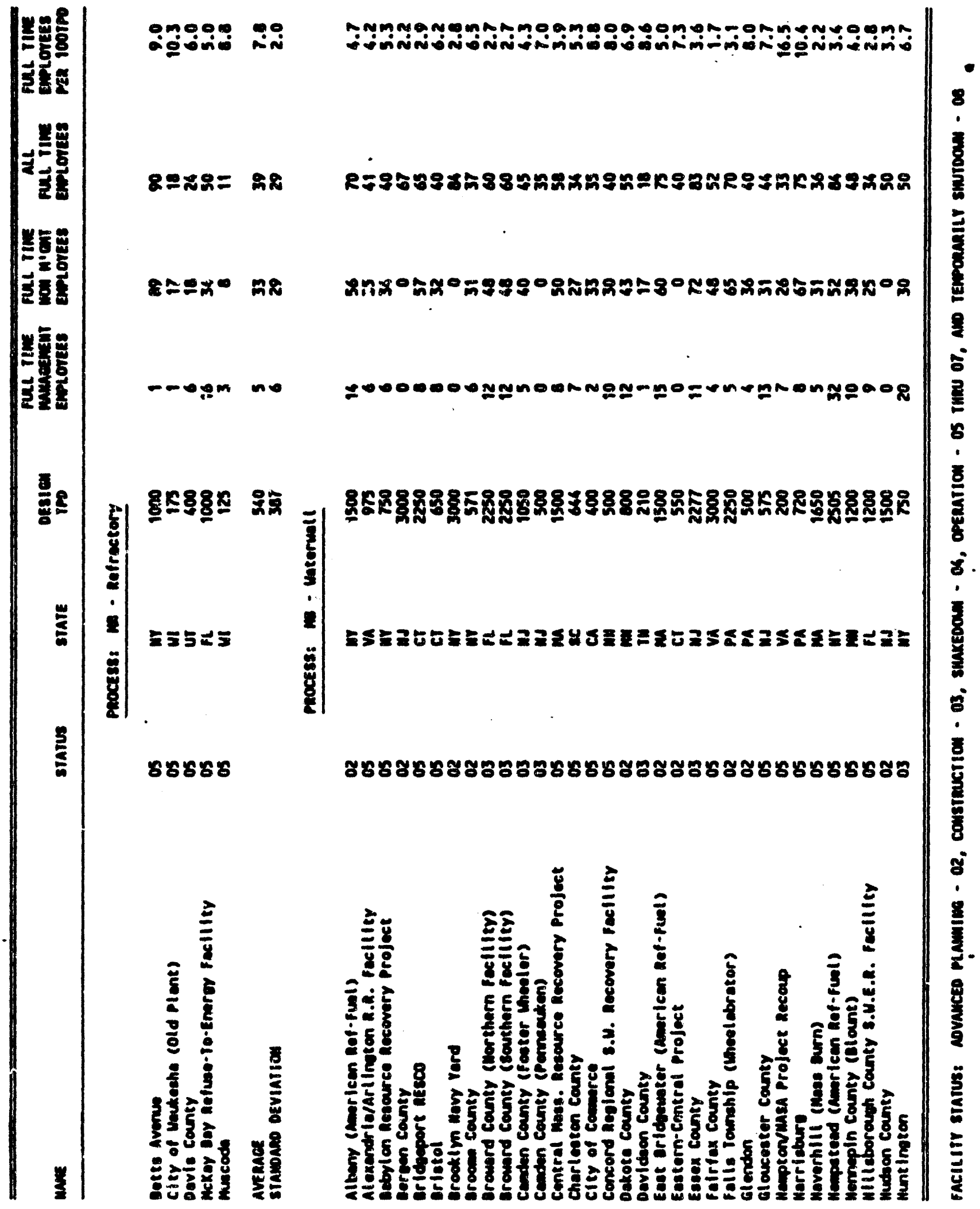




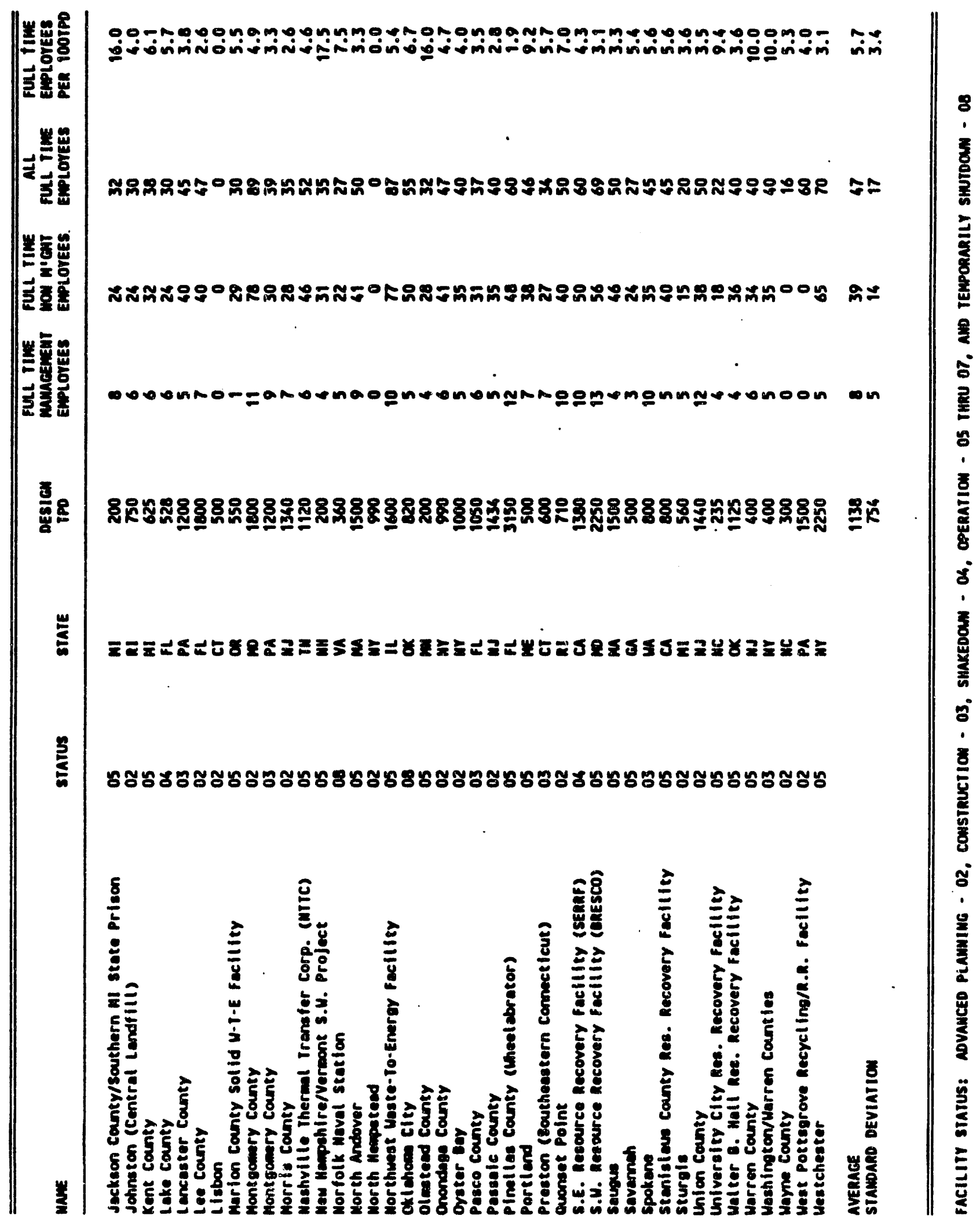




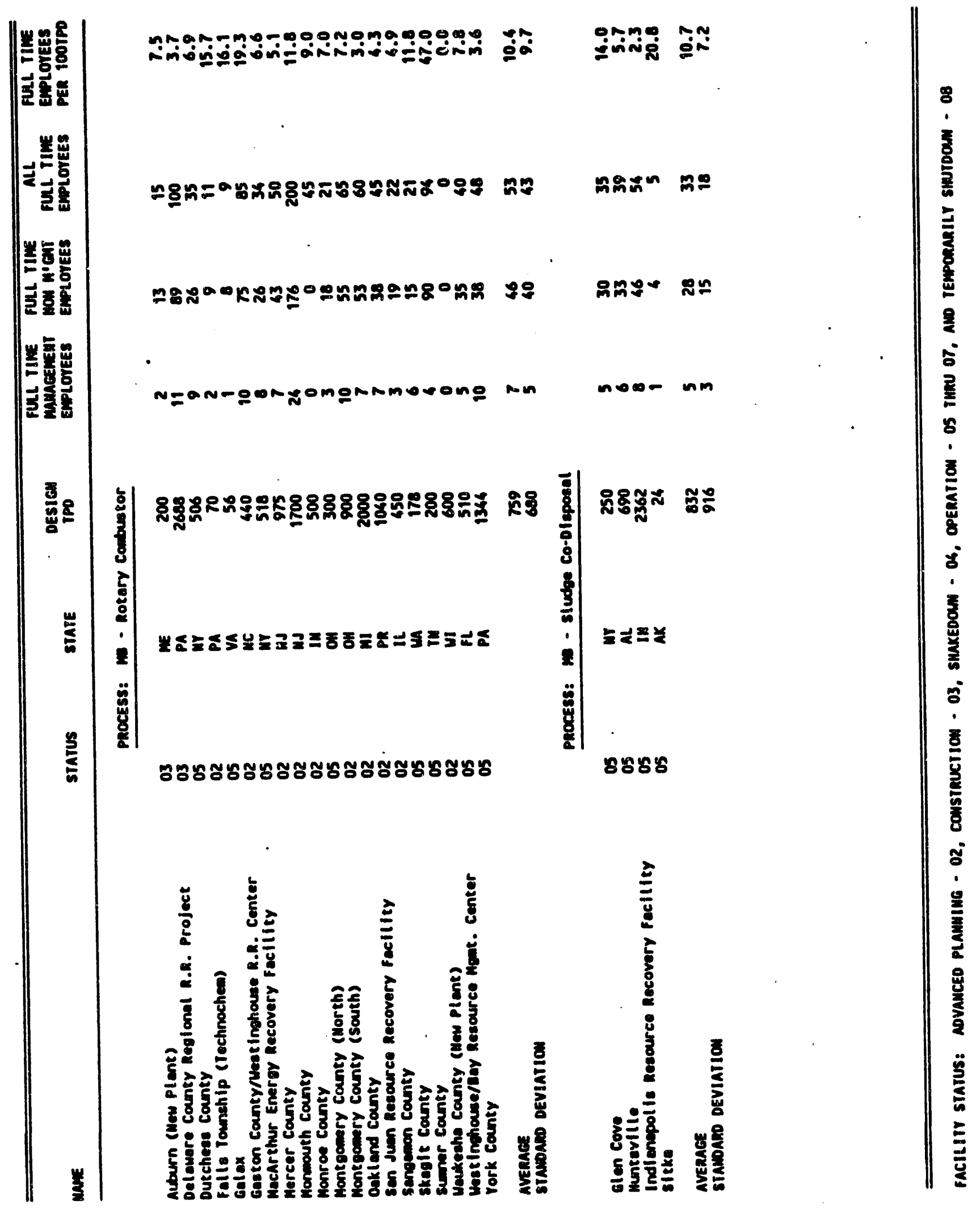


ATTACHMENT 7.

CAPITAL COSTS - MODULAR MASS BURN FACILITIES

\section{GROUPED BY APC METHOD}

(Derived from 387) 


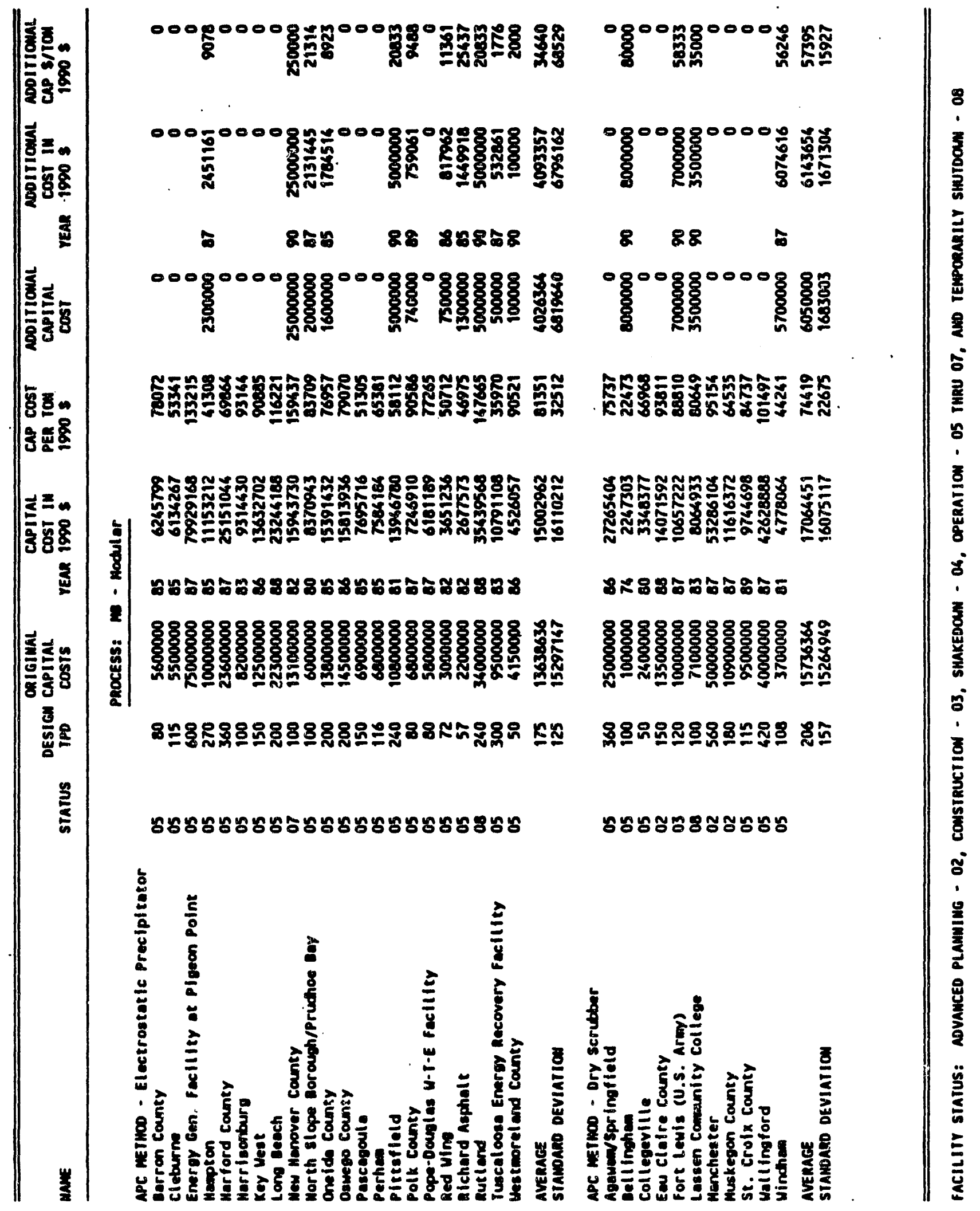




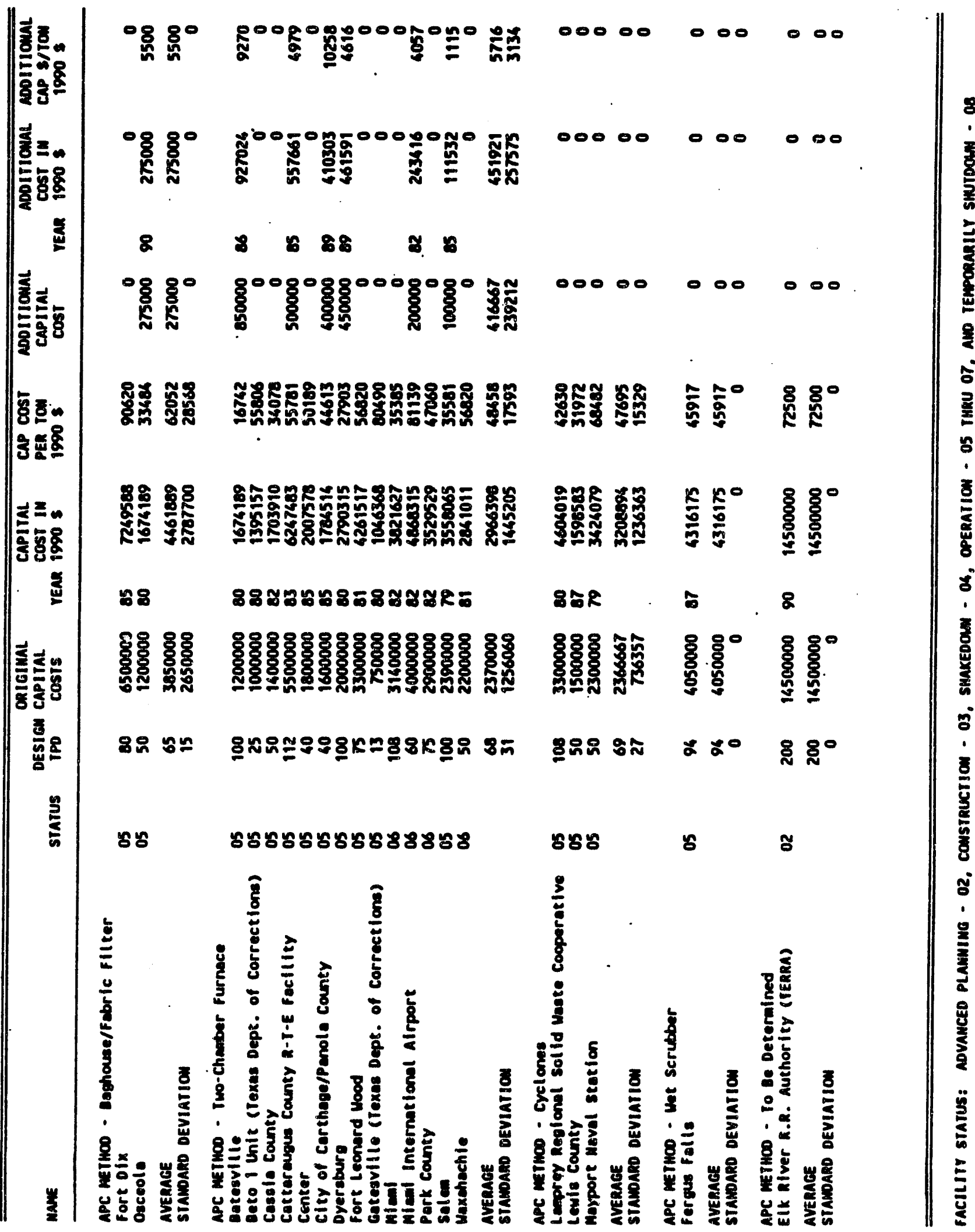

,


ATTACHMENT 8.

CAPITAL COSTS - MODULAR MASS BURN FACILITIES

GROUPED BY TYPE OF ENERGY PRODUCTION

(Derived from 387) 


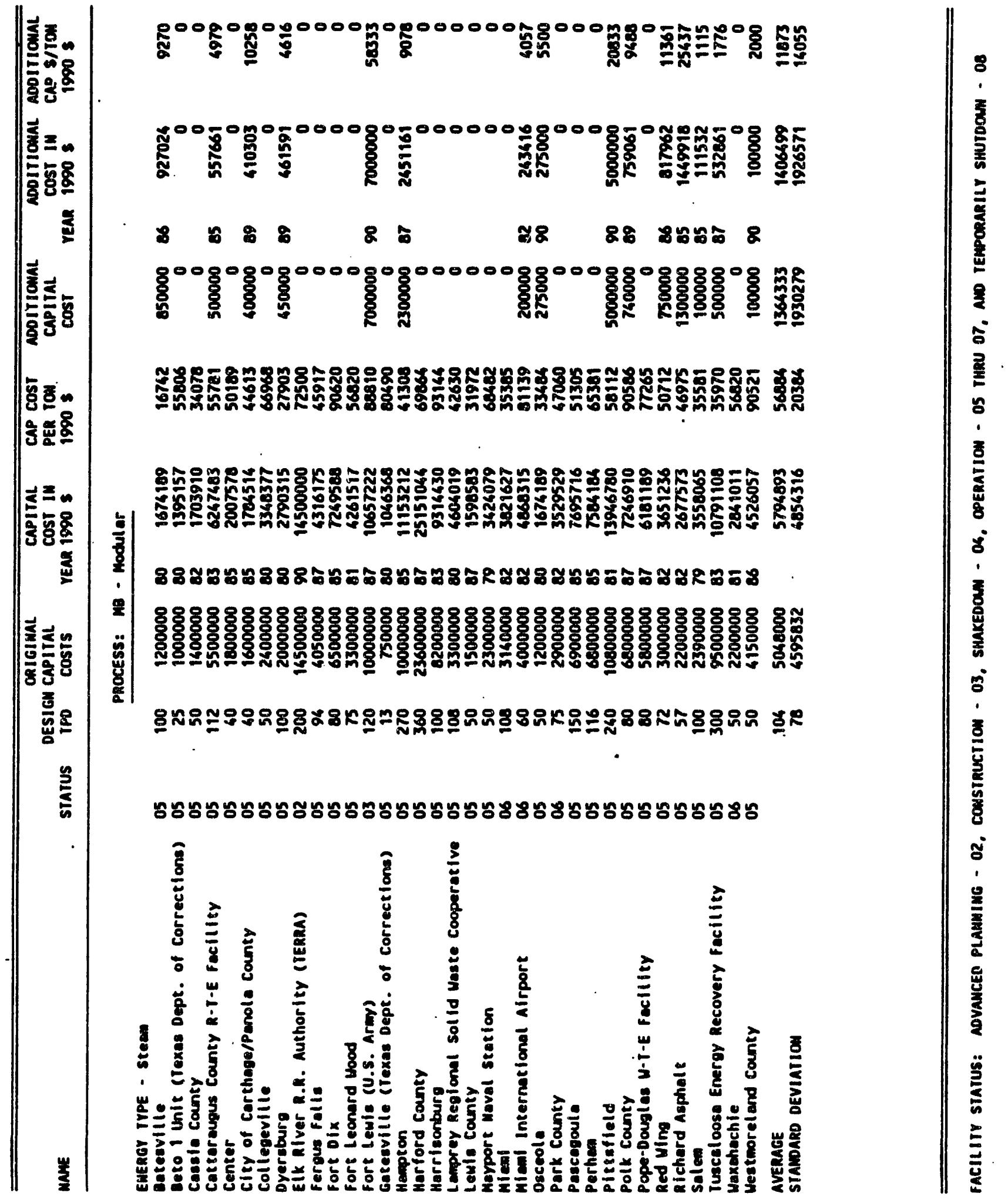




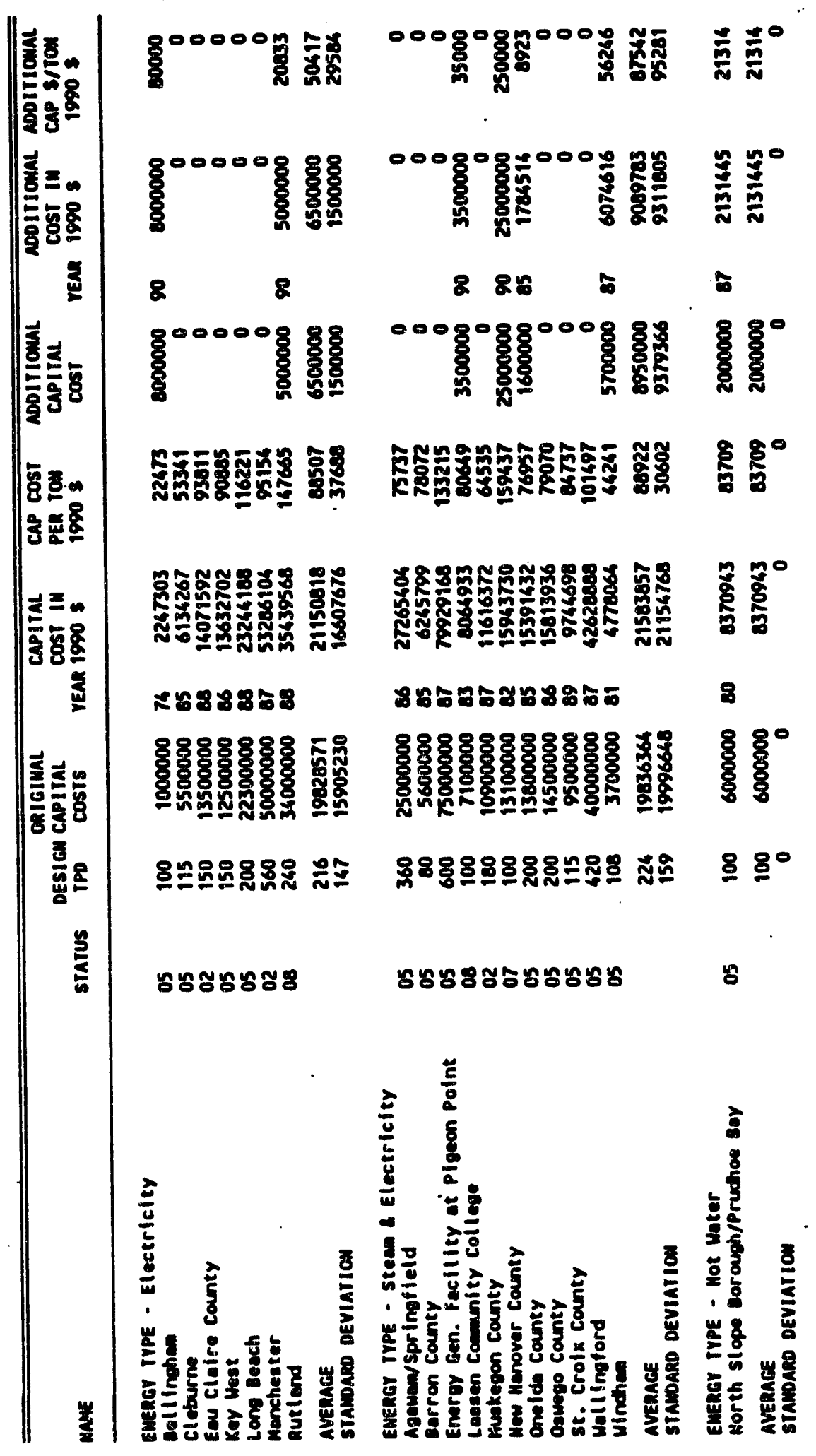

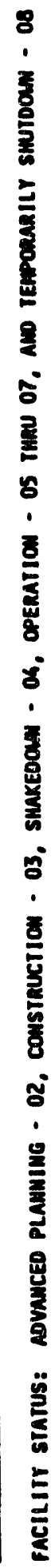


ATTACHMENT 9.

O\&M COSTS - MODULAR MASS BURN FACILITIES (Derived from 387) 


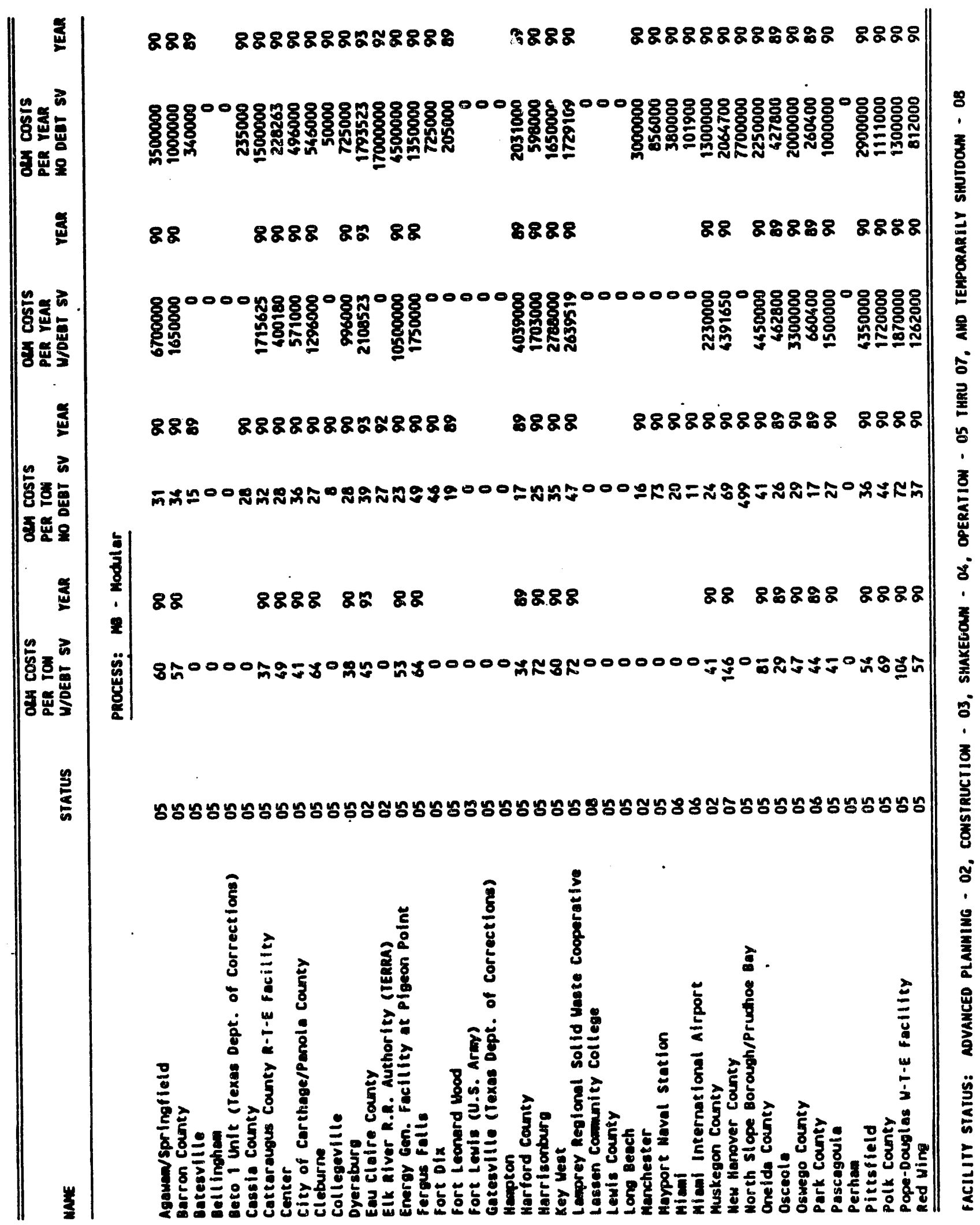



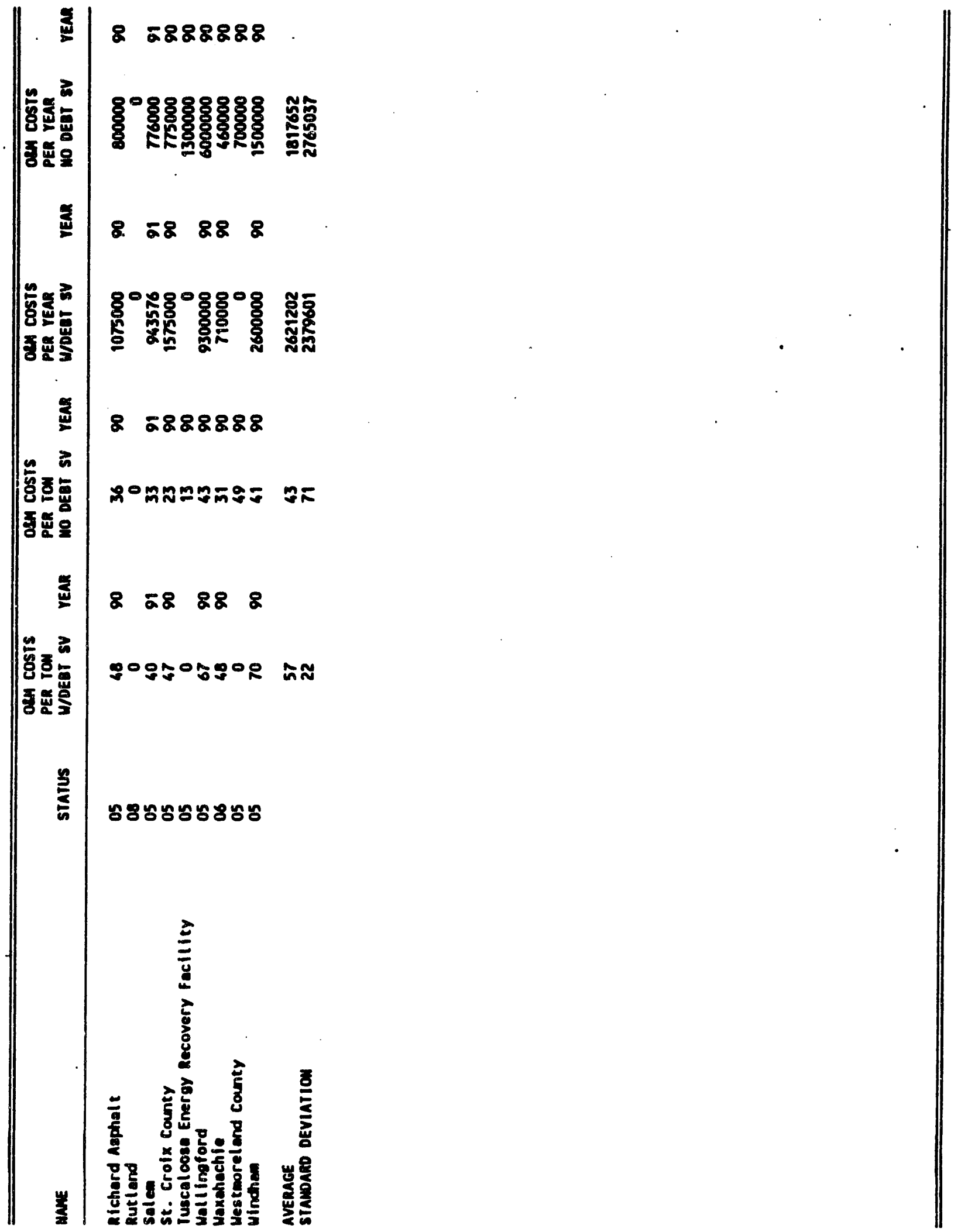

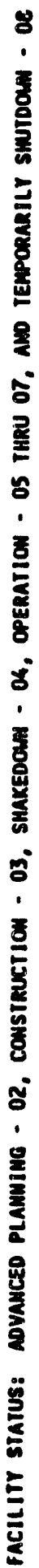


ATTACHMENT 10.

STAFFING LEVELS - MODULAR MASS BURN FACILITIES

(Derived from 387) 


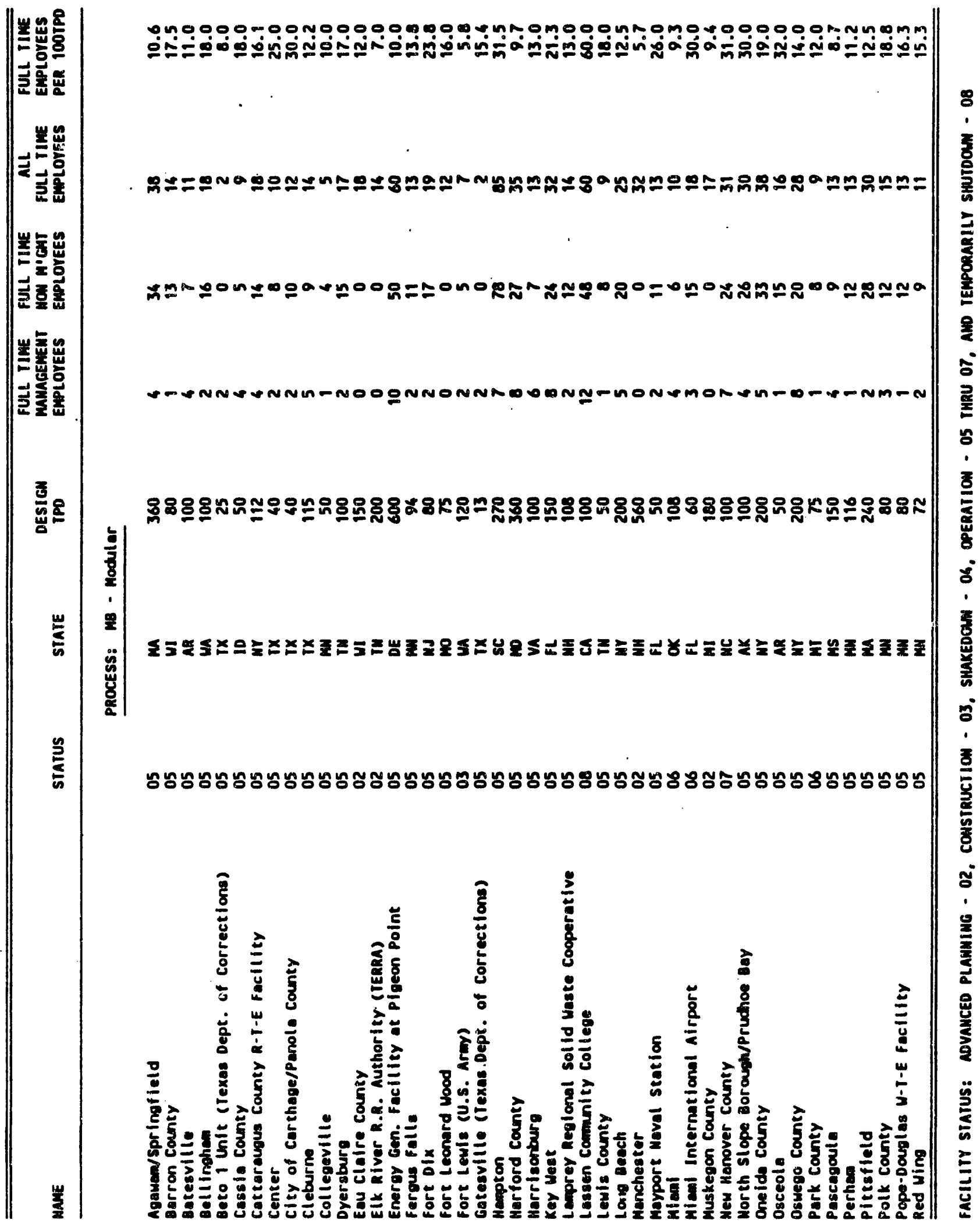




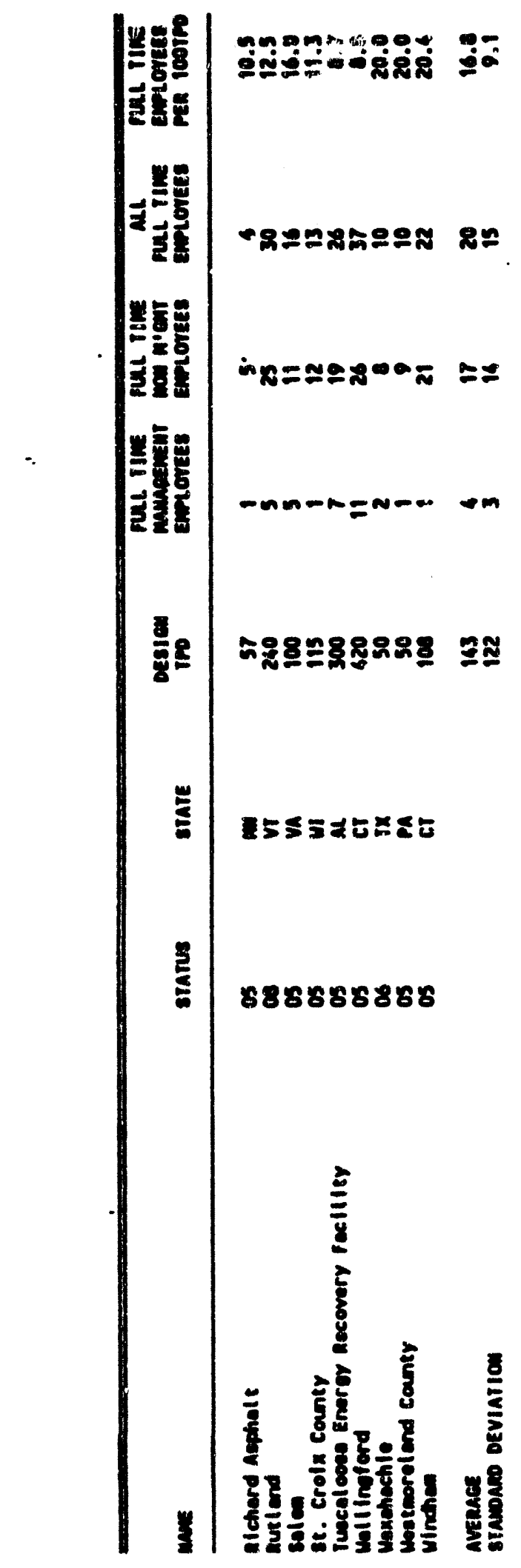

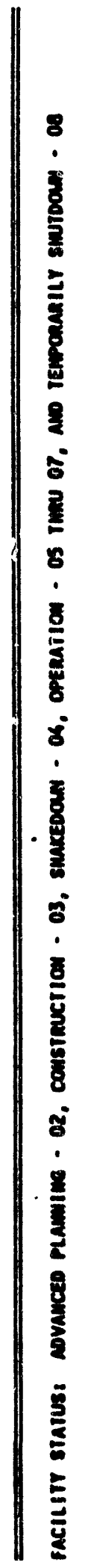


ATTACHMENT 11. POWER PRODUCTION

MASS BURN FACILTIES

(Derived from 387) 


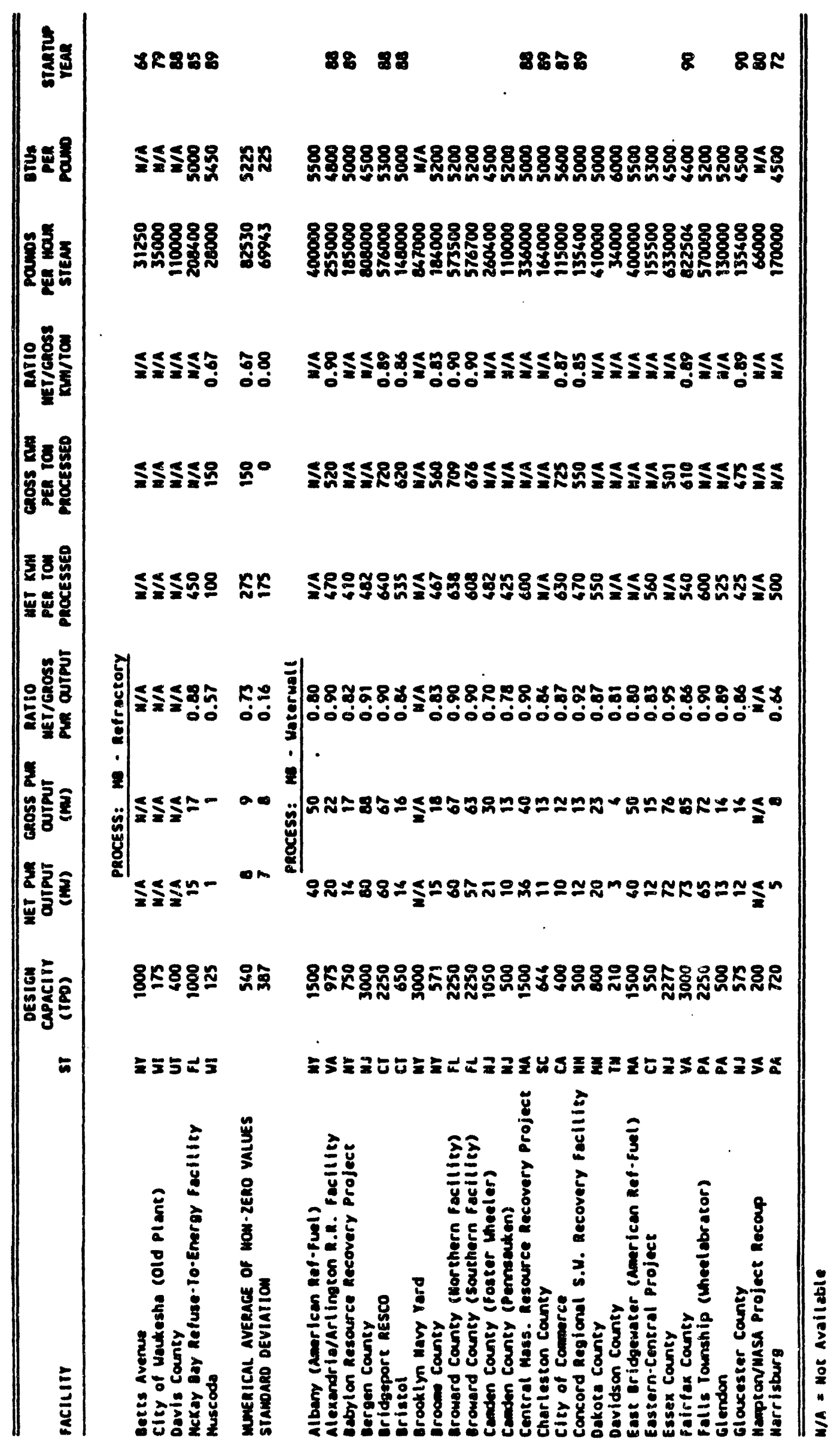




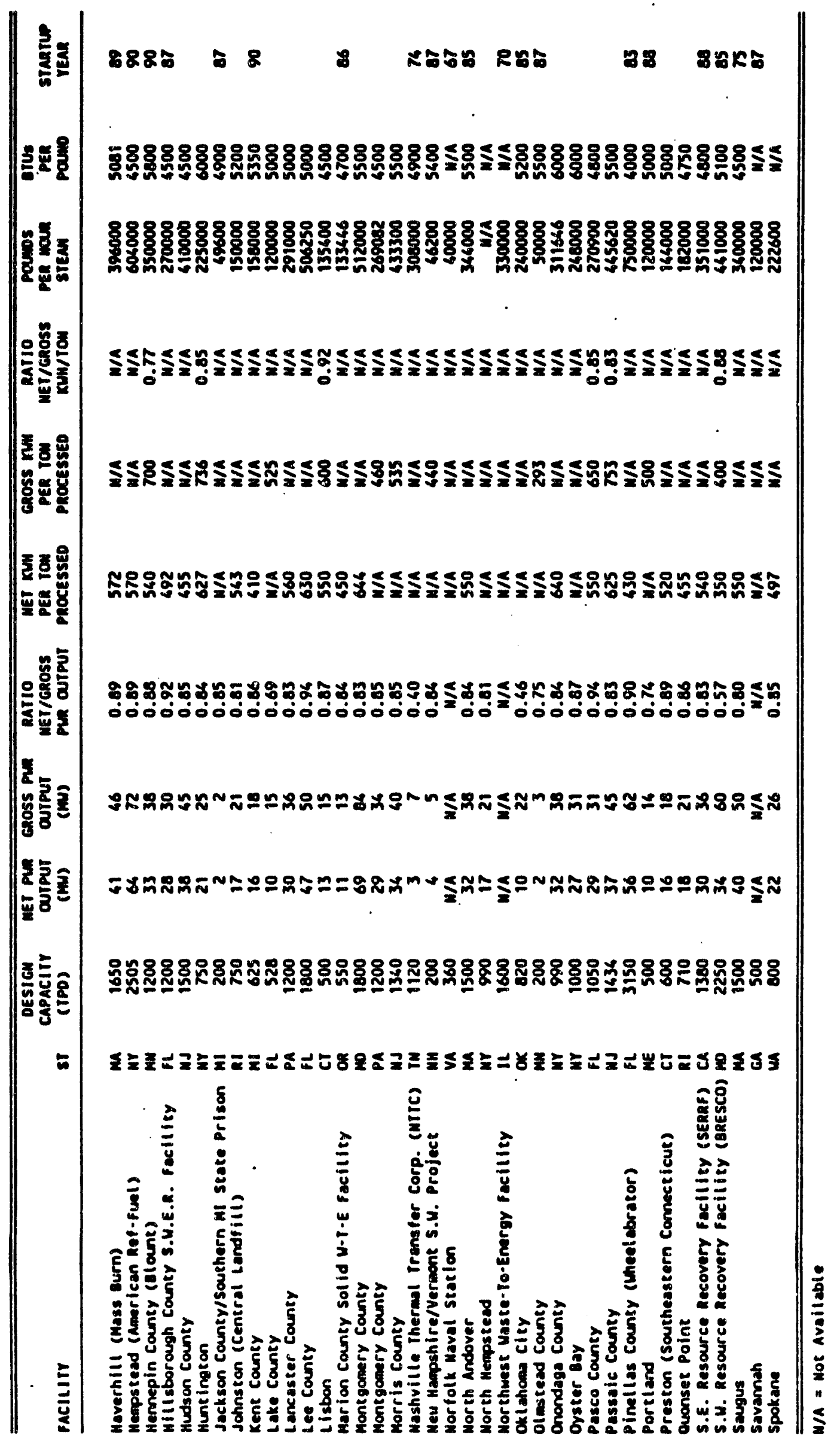




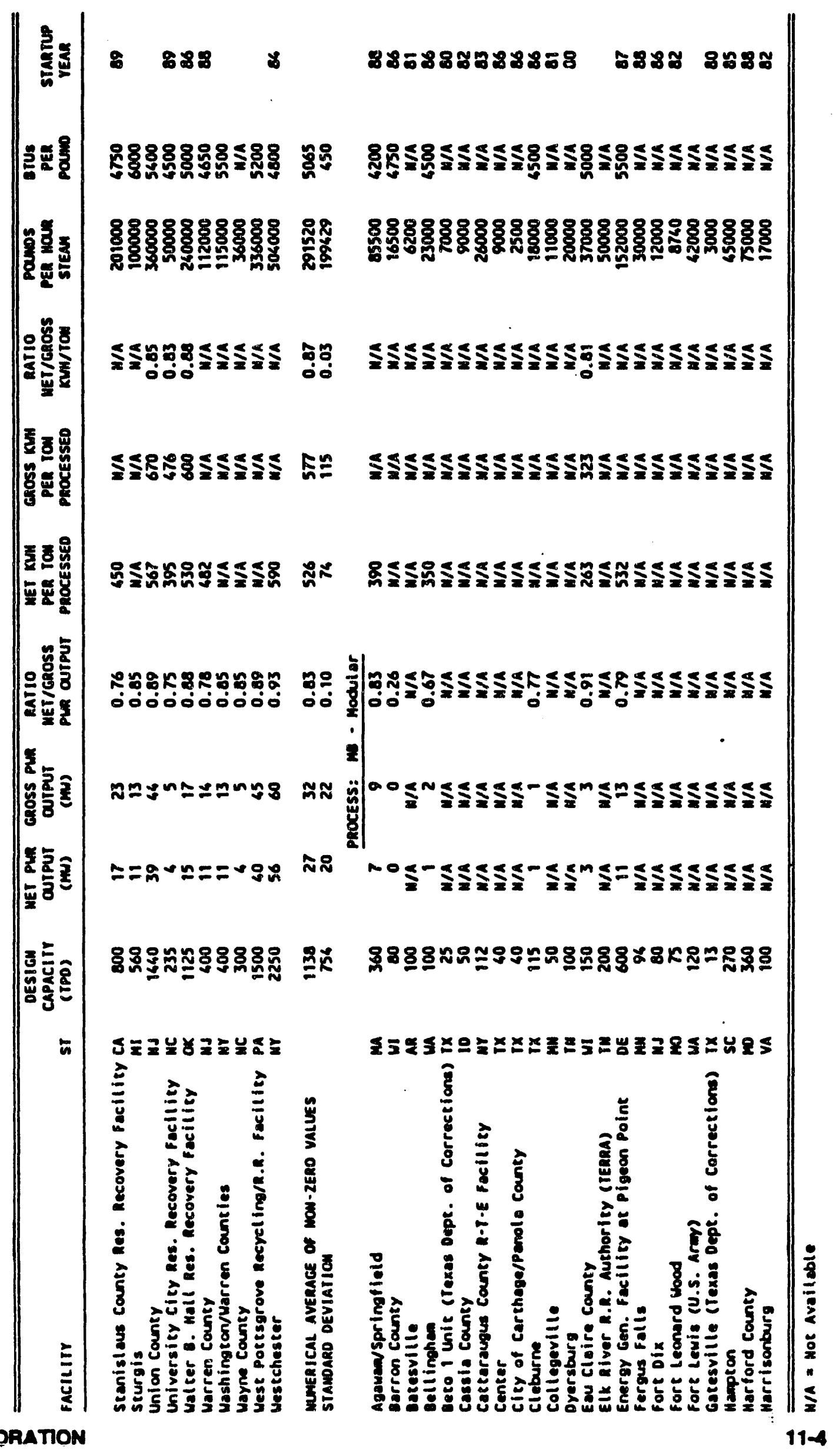




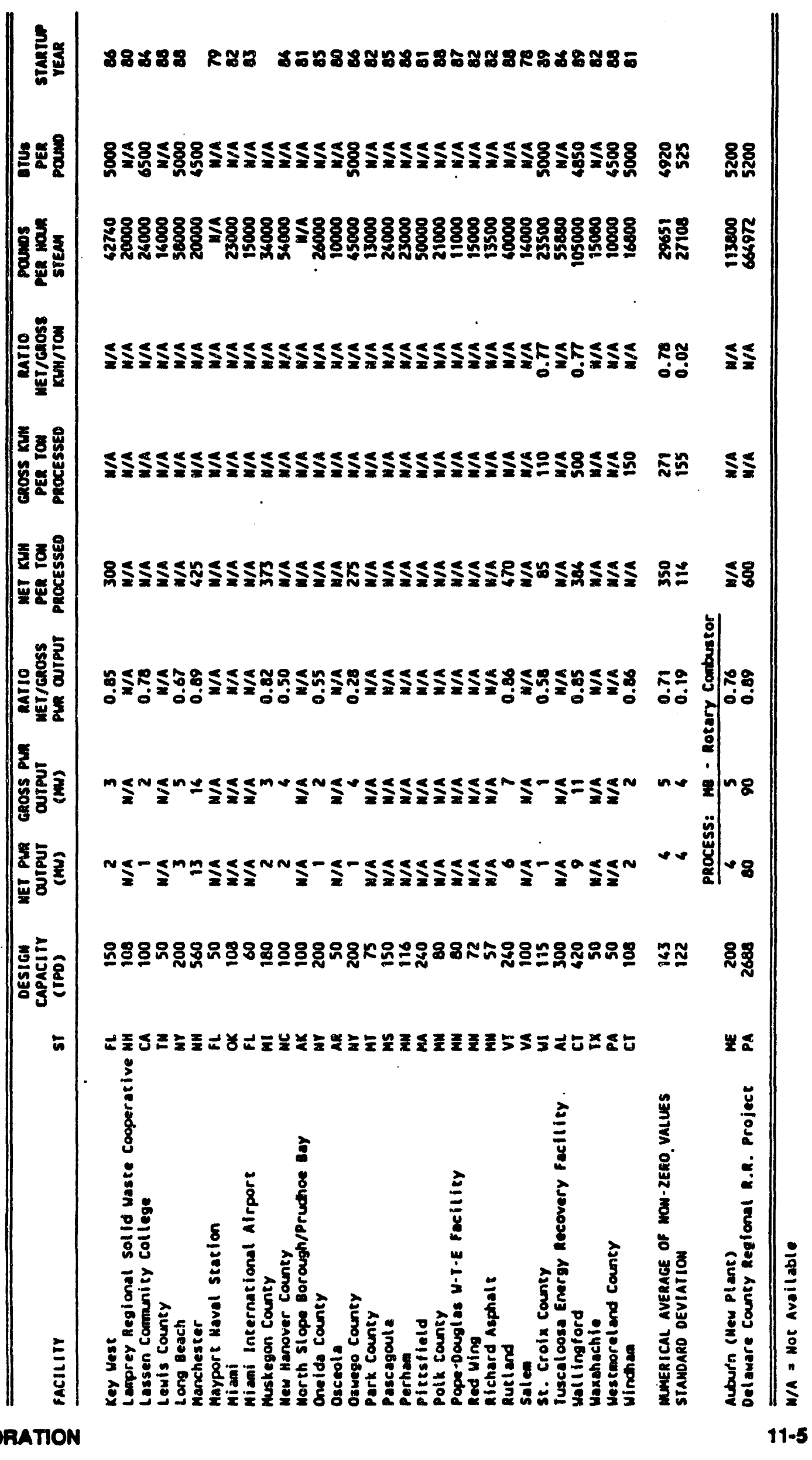




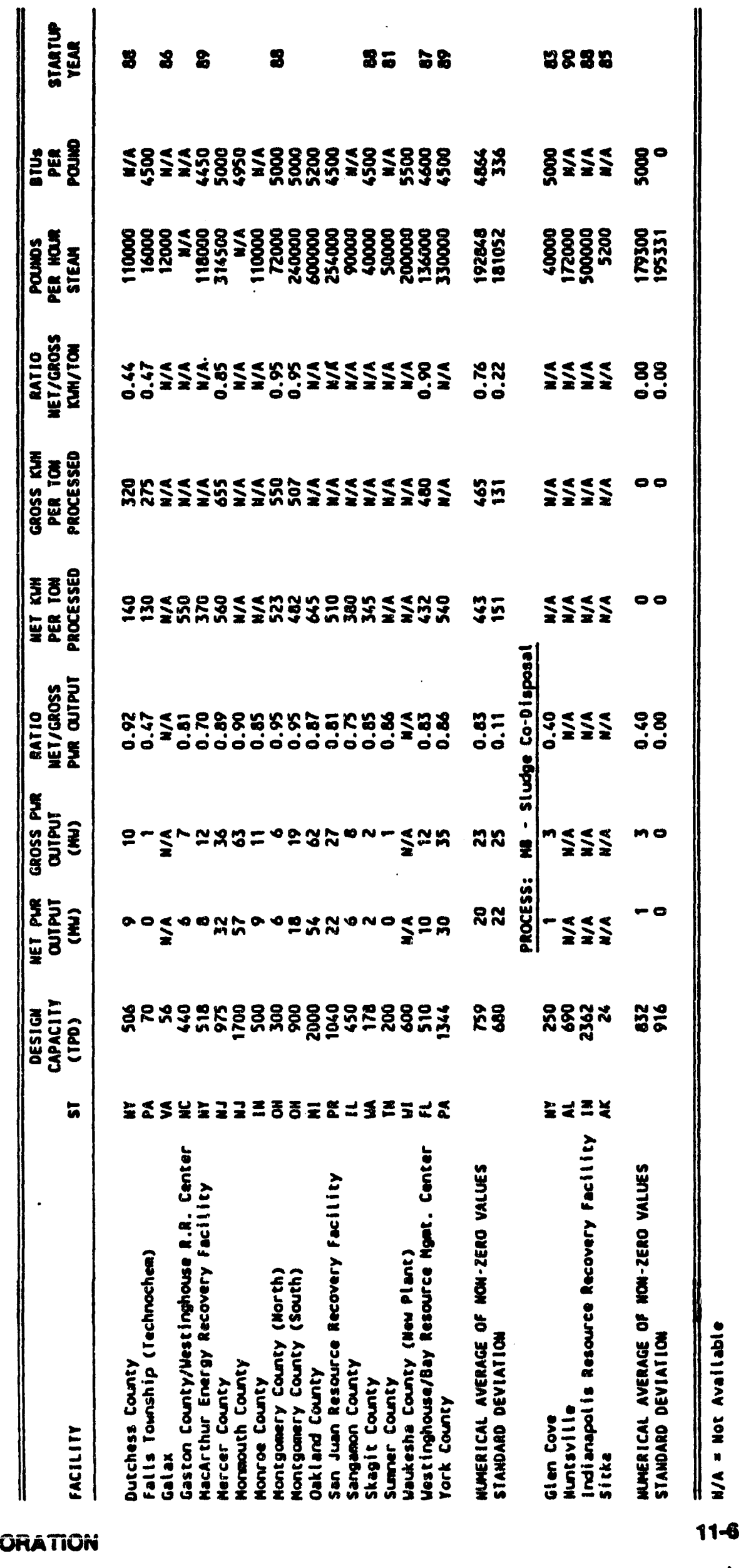



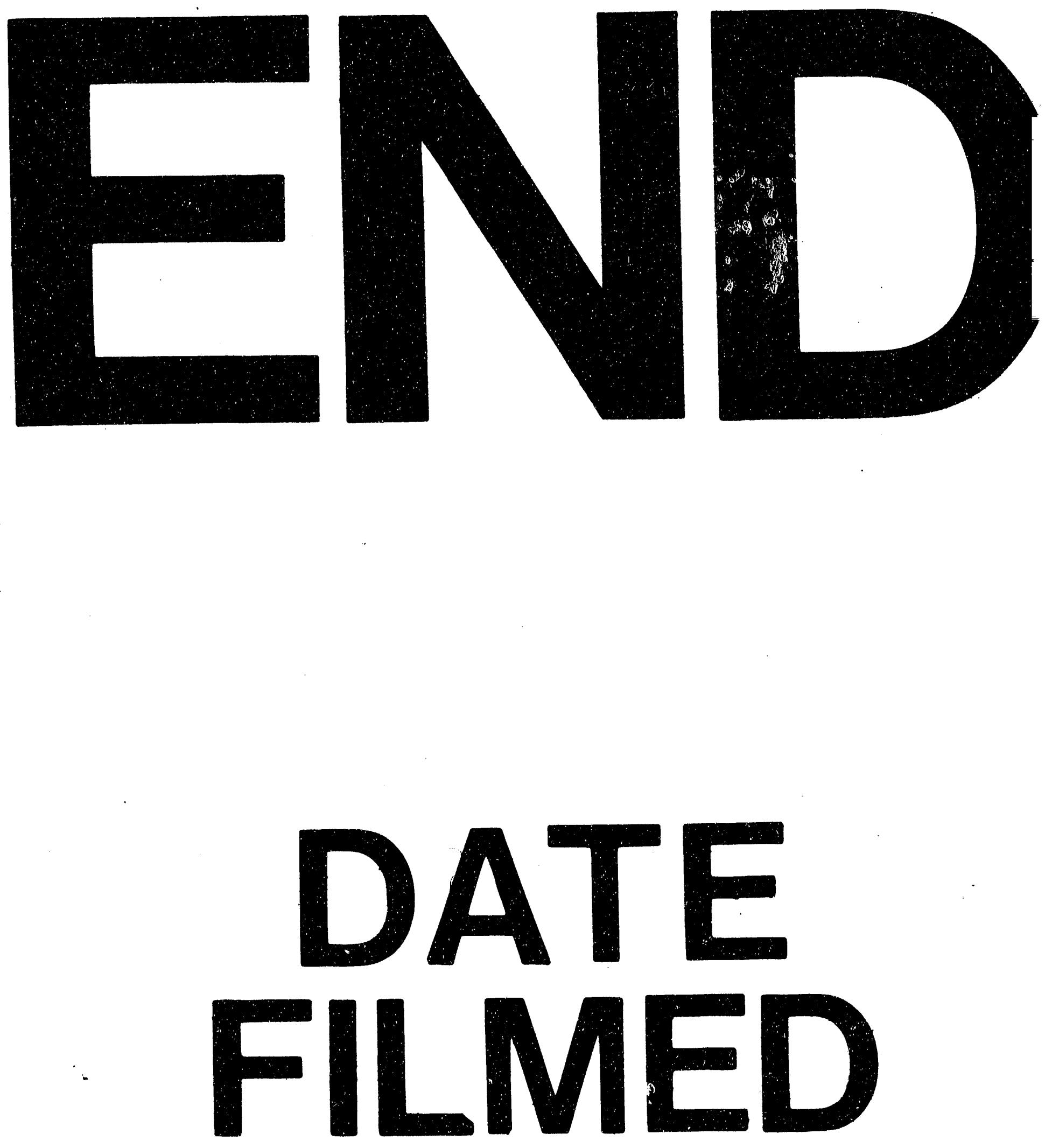

1

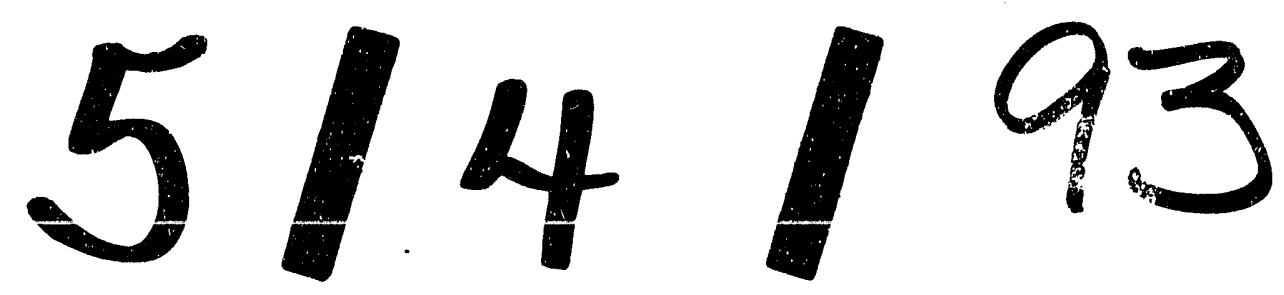


